\title{
Style Hongrois. Hungarian Elements in the Works of Haydn, Beethoven, Weber and Schubert
}

\author{
Csilla PETHÖ \\ Budapest
}

\section{The Verbunkos}

19th century European art music acquired a special hue from integrating Hungarian stylistic elements into what is collectively called style hongrois. A stylistic analysis highlighting this phenomenon cannot do without an insight into the repertory from which the western composers could draw, whose elements they could borrow as components of a foreign language whenever they wished to lend a work a Hungarian character. This repertory is none other than the verbunkos, which was the core of 19th century Hungarian national art music.

The history of the verbunkos spans over a century. Bence Szabolcsi divided it into three periods: ${ }^{1}$ early verbunkos (1750-1810), flourishing verbunkos (1810-1840) and late verbunkos (1840-1880). In Szabolcsi's opinion, the beginning of the early phase could be set otherwise, by dating its "heroic age" from the appearance of the first publications, i.e. $1780 .^{2}$ Other researchers - Bálint Sárosi, Géza Papp - also found this date to be decisive. In his book on Gypsy music Sárosi put the emergence of the verbunkos to the 1780/90s. ${ }^{3}$ Similarly to Szabolcsi, Papp differentiated three periods within a narrower span: the first from 1780 to 1805 , the second from 1805 to 1830 and the third from 1830 to $1850 .{ }^{4}$ As the different periodization suggests, the beginnings of the verbunkos are in obscurity, possibly having already had a long unwritten tradition before being put to paper. The music of the initial phase is therefore harder to define; by contrast, the stock of material avail-

\footnotetext{
1 Szabolcsi: $M Z K$, p. 68.

2 Szabolcsi: AXIX. század,p. 156

3 Sárosi: Cigányzene, p. 80.

4 Papp: Korai verbunkos, p. 228.
} 
able in publications or at least in handwritten scores from the early $1780 \mathrm{~s}$ constitutes a firm ground for today's research into verbunkos music. This paper ignores the dance tunes in 18th century handwritten collections conceivable as the precedents of the verbunkos and does not go beyond the date of 1830, studying the phenomenon of style hongrois in the works of two masters of early romanticism, Carl Maria von Weber and Franz Schubert.

\section{The Early Verbunkos}

Szabolcsi claims that the main lineament of the verbunkos repertoire is its crystallized vocabulary or set of formulae. ${ }^{5}$ The main components are period structured melody, symmetric construction, sequences, firm major-minor tonality, dotted and other characteristic rhythms (anapaest, choriamb and syncopation) and some melodic figures of which Szabolcsi named a few, such as cambiata schemes, tied notes, triplet passages, bokázó. $^{6}$

An examination of the early verbunkos reveals that these melodic figurations often in conjunction with certain rhythmic patterns became decisive for the entire material. The verbunkos publication edited by Papp gives an overall picture of this early repertory. ${ }^{7}$ The 17 sets of dances it presents contain 234 pieces by both anonymous and known composers. The anonymous ones include, among others, 4 books of Originelle ungarische Nationaltänze and Ausgesuchte Ungarische Nationaltaenze im Clavierauszug von verschiedenen Ziegeunern aus Galantha including the pieces notated after the guest performance of the Galánta Gypsies in Vienna in 1787. The early verbunkos compositions by known composers are represented by one work by Joseph Bengraf, Stanislaw Ossowski, Anton Zimmermann, Franz Paul Rigler and Carl Kreith each. Both these and the publications without name confirm that in the early verbunkos repertory the musical material filling the formal frames was nothing but a set of some typical distinct melodic turns, melodic "building blocks" or patterns in the narrow sense of the phrase. It cannot be accidental in view of the fact that the first performers of the repertory, the Gypsy musicians, played without score, improvising a lot. ${ }^{8}$ This applies not only to the initial phase of the verbunkos when, to use a phrase by Szabolcsi, "the tradition of old Hungarian music making"9 merged with the

\footnotetext{
5 Szabolcsi: $A X I X$. század, p. 151.

6 Idem, pp. 152-153.

7 Papp: Hungarian Dances

8 Sárosi: Verbunkos, p. 4.

9 Szabolcsi: $M Z K$, p. 58
} 
early verbunkos, but also to the period when the fixing of the repertory was already going on and it began to be a valued component of art music. This is also illustrated by a much-quoted article from the Allgemeine Musikalische Zeitung of Leipzig, dated 1800:

Fast alle Stücke, die in den Zirkeln der N[ational] Ungarn gespielt werden, sind das augenblickliche Produkt der Phantasie. Da stellt sich nicht selten ein Mann, wenn ihm die Stücke der Musiker nicht gefallen, vor die Musiker hin und trillert ihnen die Töne, die ihm gerade einfallen, oder die er von andern Musikern hörte, so lang vor, und lasst sie sich einzeln so lange nachfiedeln, bis die Virtuosen aus denselben ein Ganzes heraus zu fiedeln vermögen. Hieraus kann man sich auch das Einförmige erklaren, welches allen ungarischen Tanzen eigen ist. Man sieht daraus aber auch, woher es kommt, dass ein und dasselbe Stück, von verschiedenen Gesellschaften gespielt, sehr verschiedenartige Modulationen hat. ${ }^{10}$

This type of music-making needed a set of predetermined elements which could be varied at will and from which a work could be constructed. The thoroughly investigated early verbunkos dance movements possibly preserve traces of this performing tradition using prefabricated melodic patterns. Not only the pieces that were subsequently written down after the live performance (Dances of Galánta) but also those whose circumstances of origin are completely vague as yet (series of Zingarese, Hongroises, Ungarische, etc. by anonymous composers) as well as sets by named composers behave like this. Thus, the early verbunkos dance movements coalesced into a basically unified repertory in which the pieces have no individual profile or character. The latter is not substantially influenced by tempo or tonality either, for no matter whether the piece is in a major or minor key and Presto or Largo tempo, the patterns repeated from movement to movement are the same. Or, they are and yet they are not the same: namely, a single melodic pattern could have very many variations. This set of patterns is actually kept alive by variation, hence within the homogeneity it displays it is highly variable. In order to see the working of this fact in the musical material, one must give a detailed account of the components of the stock.

The melodic patterns always fill out the given formal frame and must be interpreted with reference to it. This formal frame is in most cases an 8-bar period (pieces are usually built from several such periods), with asymmetrical or 6-bar units being exceptions. The patterns are most consistent in the cadential or the penultimate bar. The most frequent closing formulae include embellished variations of repeated crotchets at the same pitch or jumping an

10 Quoted by Papp: Hungarian Dances, p. 15. 
octave (Figure 1). These melodic turns are firmly fixed enough, meaning that few are the cadential patterns that would appear at the beginning or in the middle of a period. The most pregnantly Hungarian closure, the so-called bokázó (Figure 1, line 1, pattern 3) is an unexpected and intriguing exception. The patterns used in the bar prior to the closure - variations of turn or scale motifs and those with progressiv anticipations or triads (Figure 2) are less rigorously fixed. Some specimens regularly appear with cadential formulae, whereas there are many that can often occur in other positions within the period. The patterns of the semi-cadences (closing the first half of the period) are also relatively firmly fixed. They circumscribe the dominant level with various figurations and rhythmic variants (Figure 3). Though they are by far outnumbered by the cadential patterns, they are just as typical of this stock of music. Within this group, too, there are more freely varied items. The greatest variety is shown by the beginning of movements and eight-bar units, so one can hardly speak of starting formulae. The reason must be that that is the only place where the author could add some personal hue to the piece, if he wished to. Still, there are some typical beginnings appearing at the same place of several dance movements (in bar 1 or 5 of a period) (Figure 4). Finally, the patterns used freely within a period. As has been noted, there is no sharp line between "free" and "fixed" melodic patterns, with overlappings of the two being far more frequent. That means then that although the patterns were to some extent fixed, they were not rigidly treated.

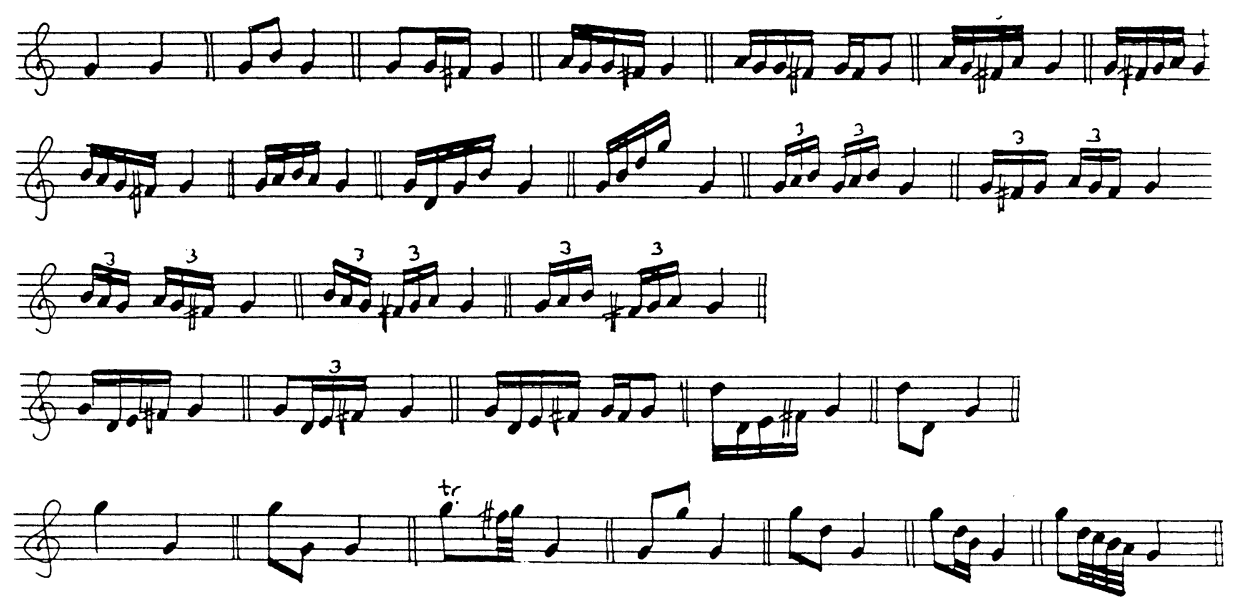

Figure 1 

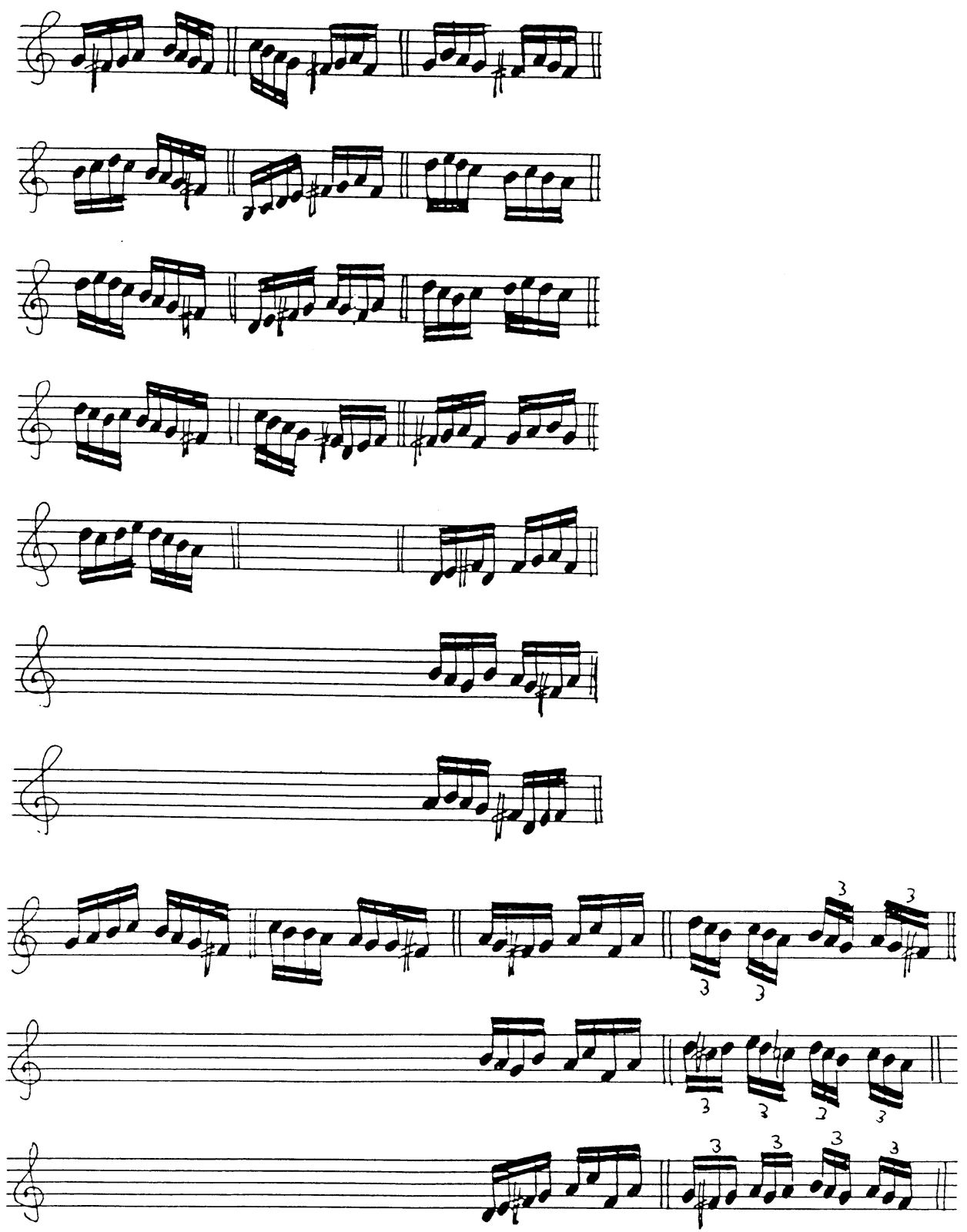

Figure 2 

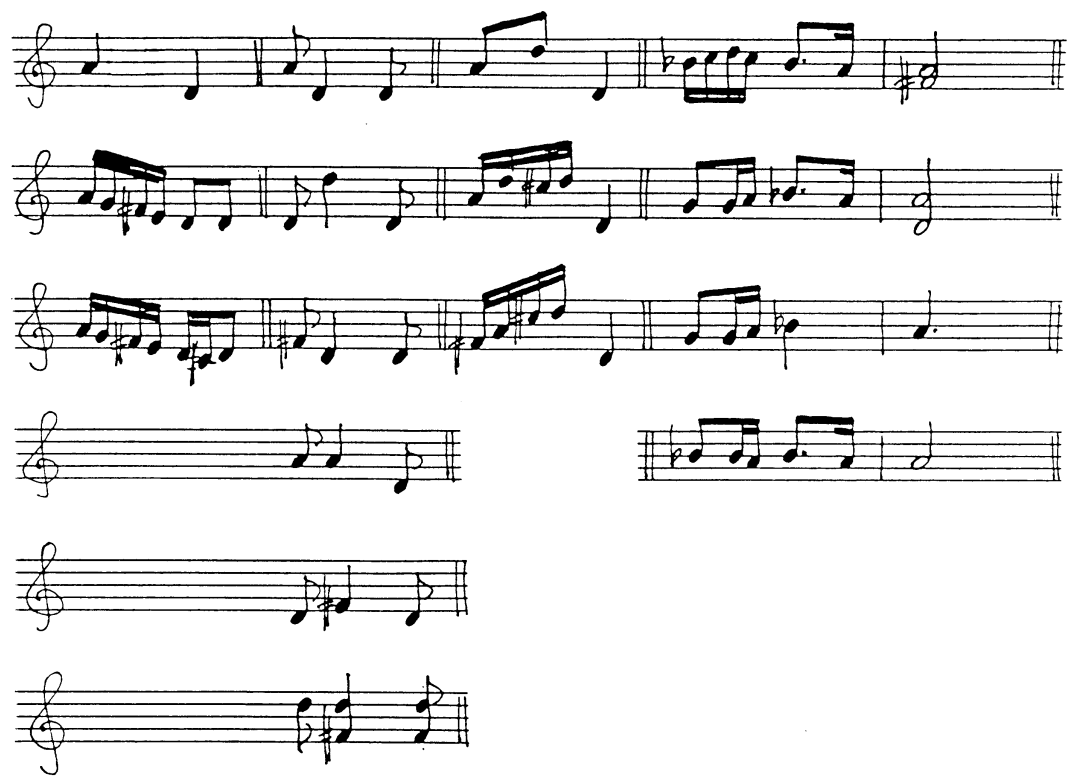

Figure 3
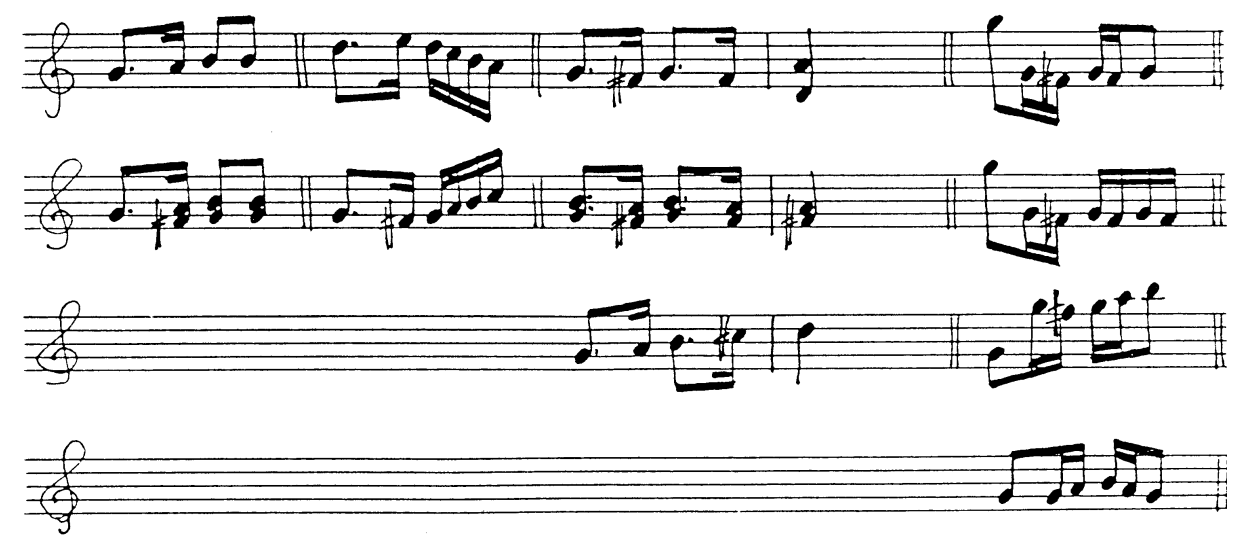

Figure 4

The rest of the characteristic features drawing on this treasury of patterns also derive from the elements of this stock. One of the most conspicuous features is the divisions of the periods. The various semi-cadential and cadential formulae constantly interrupt the musical process; occasionally even tiny 2-bar motifs may also cut up the 8-bar unit as internal closes.

The rhythmic scheme and melodic outline of the pieces are balanced. The rhythm is rarely differentiated, with combinations of crotchets, quavers, 
syncopated notes, semiquavers and dotted rhythms of quaver value dominating the rhythmic texture. Dotted rhythm of semiquaver value is still rare. Some rhythmic patterns often return in unchanged form and characterize fundamentally the material. Dotted rhythms of quaver value and their combination with two quavers are frequent at the beginnings of movements and at period heads (.5.5, 5. . . ). When crotchets are used, they also mainly appear at the beginnings or in cadences, introducing or closing off faster note values, but rarely interrupting a semiquaver progression. One of the most typical "Hungarian" rhythms, syncopation, most frequently appears in the pattern of "syncopation - bar with semiquavers-syncopation bar with semiquavers (closure)" or its reverse (when the syncopation falls on the even bars of the 4-bar unit). The continuous triplets of semiquavers promoting the diversity of the rhythm often come in to intensify the rhythm in the second half of a period, before and often in the closure. The frequently used anapaests are often paired with their reverse patterns $([., \cdot)$. These examples reveal that the rhythm allows little room for great contrasts.

The same applies to the melodic construction of the pieces. Since most patterns cover small tonal ranges, the melodies that are built from the units also remain within narrow ambits. This does not mean however that large leaps are completely omitted: they mainly appear in starting bars. But the melodic outline is usually calm, enlivened at places by broken triads and figurations preserving traces of virtuosic performance. We will search for vestiges of this virtuosity in the ornaments in vain: apart from the relatively frequent appoggiaturas there are no real Gypsy-like ornamental figures of very short note-value in these early pieces. That, however, does not mean that the early verbunkos and its expert performer, the Gypsy musician did not use ornaments: it is possibly the defect of notation that they are missing at places. The composers or transcribers of early verbunkos pieces were probably incapable of condensing in a piano score all that a small Gypsy band could perform, or else they did not wish to burden the short dances meant mainly for domestic music-making with passages requiring greater technical skills. Another feature of these early pieces is the almost complete absence of the so-called kuruc $^{11}$ fourth so popular later in Hungarian style pieces of western music (in all the 234 pieces it occurs but once).

${ }^{11}$ Kuruc: Hungarian soldier fighting in the war of independence called Rákóczi from 1703 to 1711 against the Habsburg oppression. The word's meaning as an adjective in the vernacular: pugnacious, bellicose, brave. Kuruc forth : repeated forth-leap, pendular forth . 
Owing to the functional use of the pieces, their overall forms are very simple. They mainly consist of enumerated periods changing in number. A considerable portion of the stock consists of 16 bars (two periods), but there are longer ones (those above 32 bars belong to the long ones). The musical material of the successive periods are often completely independent of each other, constituting chain-like forms: $a:\|: b:\|, a:\|: b:\|: c: l, a:\|: b:\|: c:\|: d:\|$, etc. Returns $\left(a_{1}+a_{2}\right.$ :ll: $\left.b+a_{2}: l\right)$ are far fewer, almost exceptions. These simple dances, however, are often arranged upon the western trio pattern, thus realizing the principle of recapitulation at a higher level.

Separate mention is to be made of a formal peculiarity, the motifrepeating coda called Figura (lit. figure) or Toldalék (addition) in the scores. This typical closing section is the adoption of a manner of folk music performance, the figurative section called duda apraja. The apraja, aprózás ${ }^{12} \mathrm{sec}-$ tions of instrumental folk music are characterized by a narrow tonal range, plenty of figurations, high register and motivic repetition, ${ }^{13}$ which features can also be discerned in the closing figures of early verbunkos pieces, proving that the improvisatory playing technique of folk performers was still vigorously alive at the back of the repertory.

The harmony of these pieces can be briefly summed up. It moved within the frames of stabilized major-minor tonality even if it was at places enriched by a Lydian turn or one including an augmented second which brings some exotic, Hungarian colour. The harmonic progressions accompanying the melodies were rudimentary, almost restricted to the basic functions ( $\mathrm{T}-$ $\mathrm{S}-\mathrm{D})$ only. In the piano score, the harmonic process is ensured by the simple chordal accompaniment of the left hand.

A comprehensive study reveals that the early verbunkos is already tied to western art music at several points, borrowing many elements from it, and on the other side, the remnants of the earlier musical practice not fixed in writing are also detectable in the predetermined melodic patterns and motifrepeating technique alluding to folk music. That underlies probably the "folkloristic" variation of pieces surviving in writing: certain sections of some pieces appear as each other's variants, some elements are transplanted from one piece to another. This applies to more than the constant use of one or two-bar patterns: sometimes larger units (periods, half-periods) are also

12 Duda-aprája, apraja, aprózás: in Hungarian instrumental folk music an embellished musical section which functions as an interlude or a coda. Used equally by bagpipers and fiddlers.

13 Sárosi: Parasztok cigányzenészek, p. 151 
borrowed but it does not interrupt the musical process, for in most cases the periods are not motivically connected.

Two music examples illustrate the above said (Examples 1, 2). The two pieces in the first are thematically related. No. 167 is a massively enlarged and varied form of no. 164. The movements begin identically. The first four bars of 164 extend to eight bars in the other. In this enlarged variant, the motif in bar 3 is a variant of bar 5 in 164, and bars 4-8 are almost note-for note identical with bars 1-4 of 164 . The second part of 167 begins with new material, but the syncopated cadential patterns refer back to the starting motif. After this second section the first period returns, constituting a form with a trio (main section in d minor, 8 bars - trio in a minor, 8 bars - main section in $\mathrm{d}$ minor, 8 bars). As compared to this, no. 164 is "incomplete": e minor 4 bars a minor 4 bars.

In the second example, the first periods of nos 18 and 59 are almost identical, excepting the last two bars. In Ossowski's variant there is more figuration, so the melodic line is more pliable. In no. 59 bars 7-8 of the first period move towards A major just as bars 3-4 do (no clear sense of a period is experienced), while in no. 19 the modulation is into $b$ minor. From then on the two works are completely different: no. 59 adds one, no. 18 adds two eight-bar units to the first section. In Ossowski's piece, bars 9-16 are motivically tied to the first period, while in no. 59 the second half contains new material compared to the first part.

\section{Mature Verbunkos}

The music of the next phase, known mainly from the musical material in three collections (the library of the former National Music School, ${ }^{14}$ the music collection of the National Széchényi Library and the Major collection ${ }^{15}$ in the Institute for Musicology) differs from the repertory of the early verbunkos at several essential points. More than 300 movements were gleaned from the verbunkos material of the three collections for study. The pre-1828 booklets of the important miscellaneous collections of the age were just as important sources as were the separately published pieces or sets of dances of individual composers. The most important collected works of the examined period include: Magyar Nóták Veszprém Vármegyéböl [Hun-

\footnotetext{
14 At present its material can be found in the Research Library for Music History of the Ferenc Liszt Academy of Music Budapest.

15 Ervin Major's collection of data related to Hungarian music history in the Institute for Musicology of the Hungarian Academy of Sciences.
} 
[164]

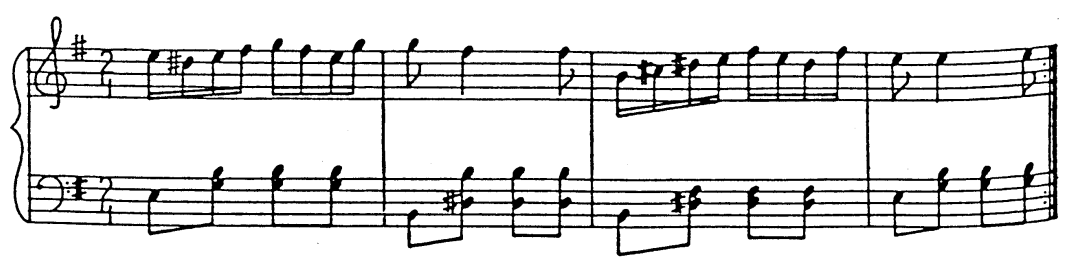

[167]
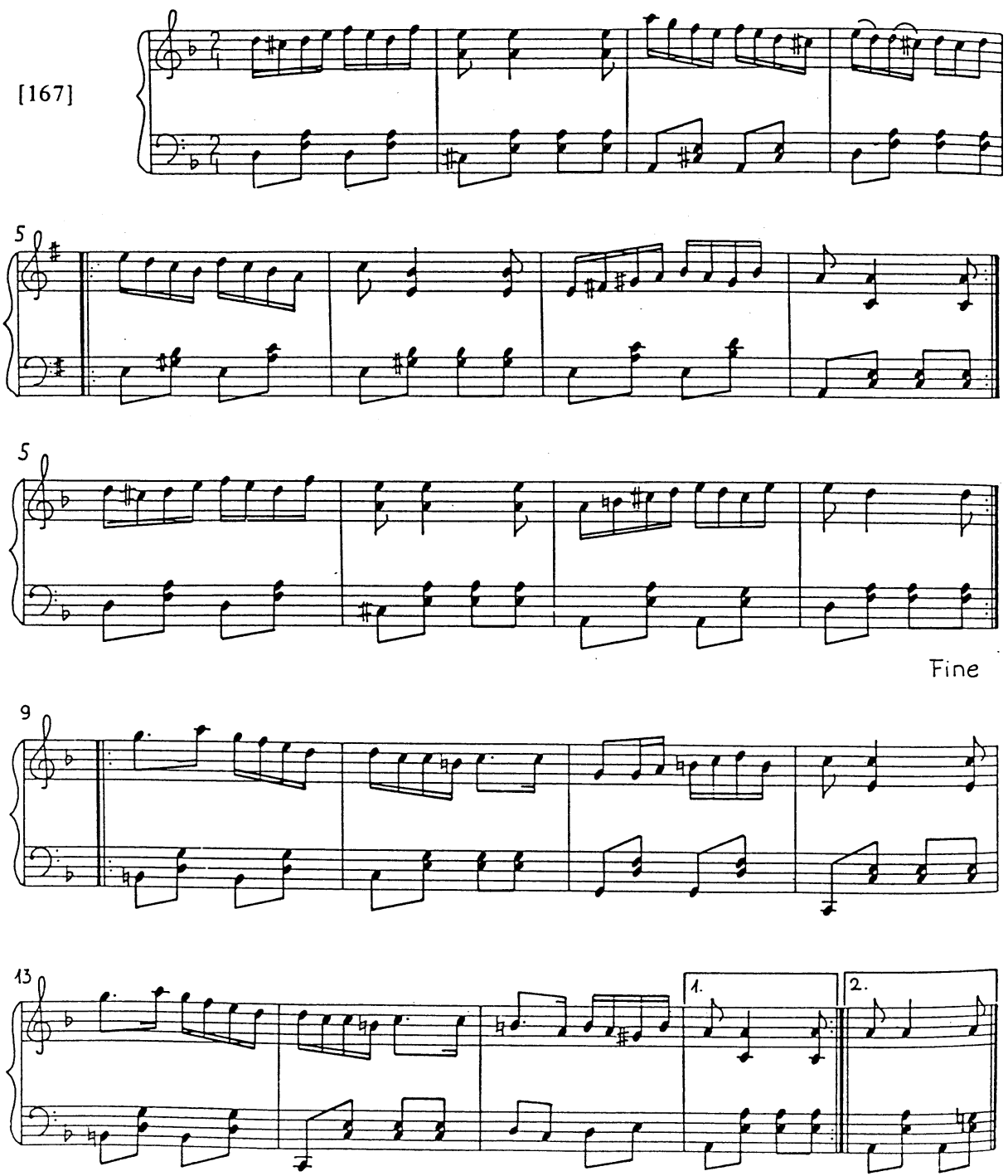

$\mathrm{DaCapo}$

Example 1: 22 originelle ungarische Nationaltänze, Heft 2, No. 19 [164], No. 22 [167] 
[18]

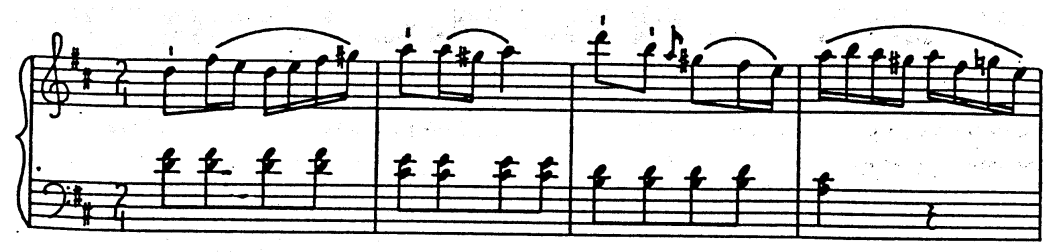

[59]
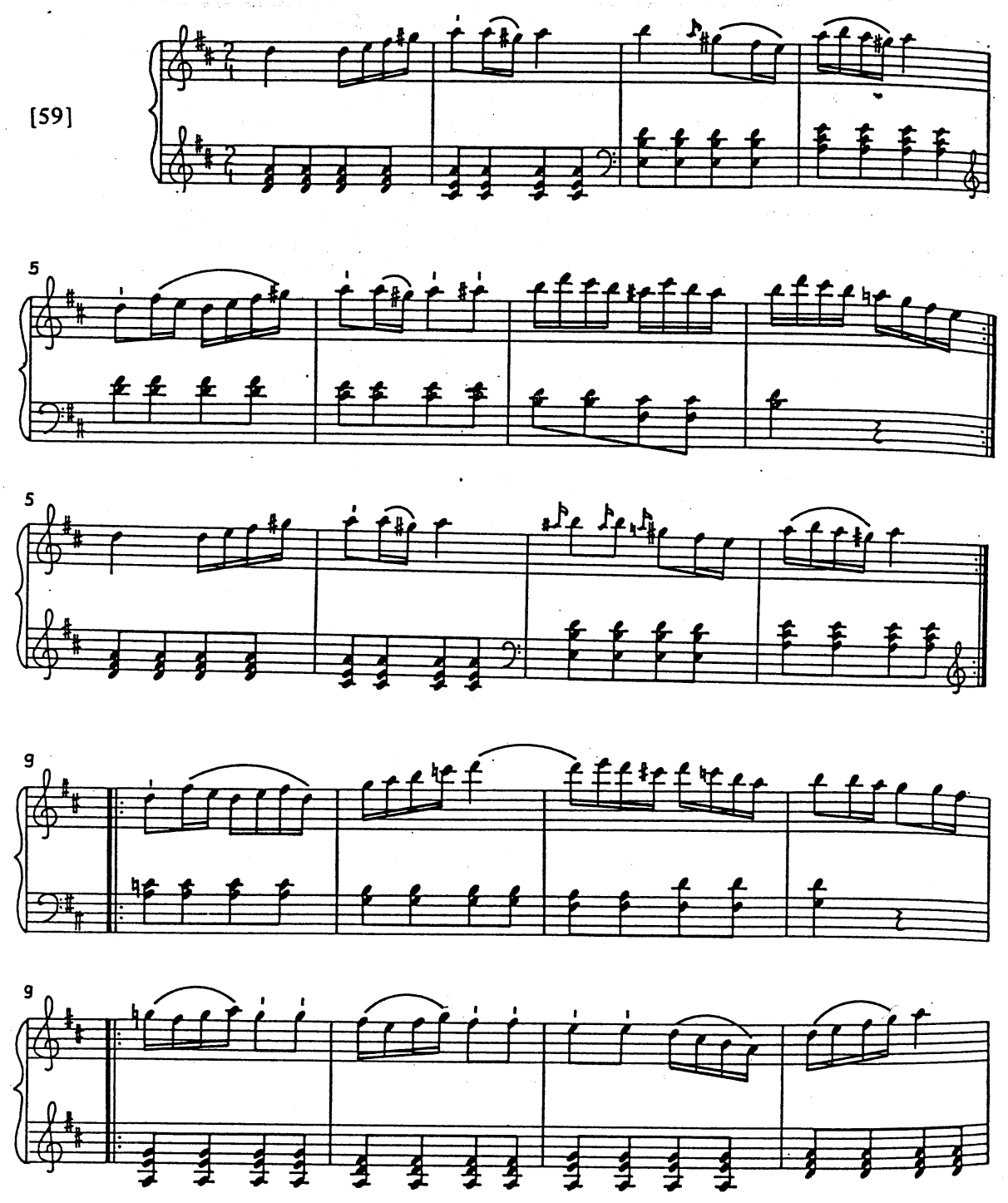

Example 2: Ossowski: 6 danses hongroises, no. 6 [18]

Unknown composer: Contredanses hongroises, no. 11 [59] 

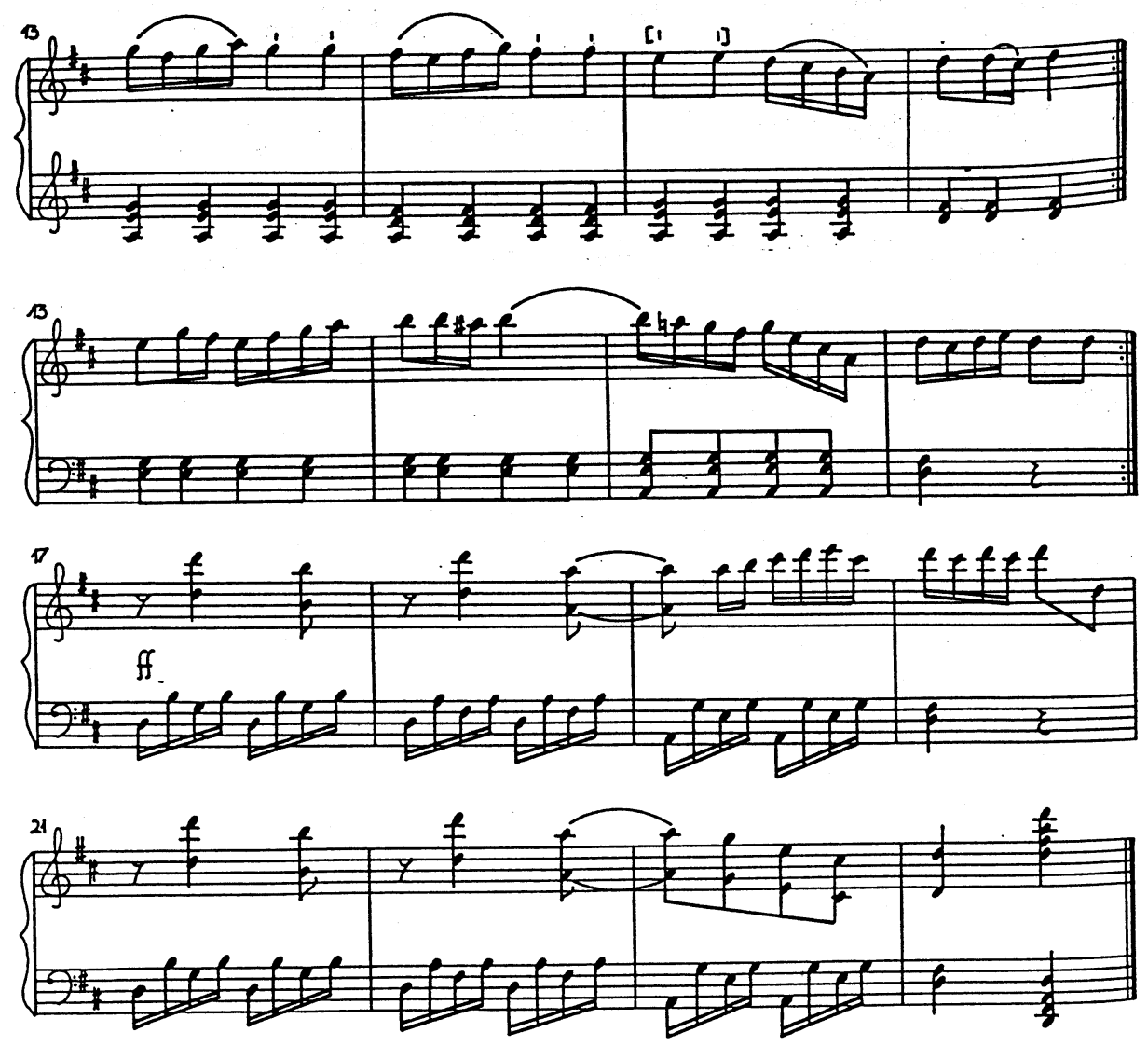

Example 2 cont.

garian Tunes from Veszprém County], a series edited by Ignác Ruzitska, the Nemzeti Magyar Tántzok [National Hungarian Dances] edited by Ágoston Mohaupt and the earliest issues of the Pannónia collection. In our examinations, the printed works enjoyed priority over handwritten sources because they were dated and a study of age-related stylistic features could be based on sure foundations. Many verbunkos composers are named in the sources. Several pieces were released by Ruzitska, Mohaupt, Gábor Róthkrepf (Mátray) the young Márk Rózsavölgyi and others, but the majority of the repertory consisted of compositions by János Bihari, János Lavotta and Antal Csermák. This fact does confirm the prevalent view identifying this period with the names of these three composers. 
The initial and mature phases of the verbunkos are not sharply separated. The 4th booklet of 25 originelle ungarische Nationaltänze was probably published in 1810 or $1811,{ }^{16}$ but even earlier there were works in print (by Csermák, Bihari and minor composers such as Ádám Berner) which belong to mature verbunkos stylistically. Bihari had two Hungarian dances (2 Ungarische Tänze) published in Vienna in 1806, Csermák composed 6 Romances Hongraises, a set of dances, in 1804, Berner's 12 Magyar Nóta [12 Hungarian Tunes] are from 1805. The gradualness of the shift from the first to the second phase in the style is well exemplified by József Kossovits's set of 12 Danses Hongroises dated to around 1800, relatively early, that is. Yet it does not fit the repertory of the early verbunkos which is mostly characterized by the set of patterns and displays stylistic traits that are typical of the mature verbunkos. Kossovits anticipated the efflorescence of the verbunkos mainly in the rhythmic differentiation of his music; that, however, is just one criterion defining mature verbunkos style. What are the features characterizing the new repertoire?

The first and most important change is the demotion of the so-far decisive set of formulae into the background. It does not mean that at certain places, principally at cadences, no bokázó or triplet pattern may appear, or some virtuosic closing figure that was infrequent earlier and became exemplary in the new phase. Nor does it mean that there were absolutely no pieces built from the former set of patterns or at least using some elements from it. The trio of the Bihari work included in a publication of 1824 entitled Ungarische Werbungs Tänze aus dem Baromettermacher is constructed from such formulae. The typical stepping crotchets of the beginning of the first bar are followed by partly repetitive, partly varied turn motifs, then in bar 4 we can recognize a fifth-filling half-close. After the ensuing turn motifs in bars 5-6, the period is rounded off by a frequent cadential formula. The second period is launched in bar 9 with progressive anticipations combined with dotted rhythm, while in bars 11-12 a variant of one of the most frequent half-closes can be detected (Example 3). The work illustrates that, on the one hand, the stylistic change between the two periods of the verbunkos was not all of a sudden, and on the other, the style of the former repertory - restricted though to fast movements - could live on.

At that time, however, cases like this were rather exceptional, just as the variability so typical of the early verbunkos can only rarely be discerned in

16 Papp: QVMI, p. 195. 


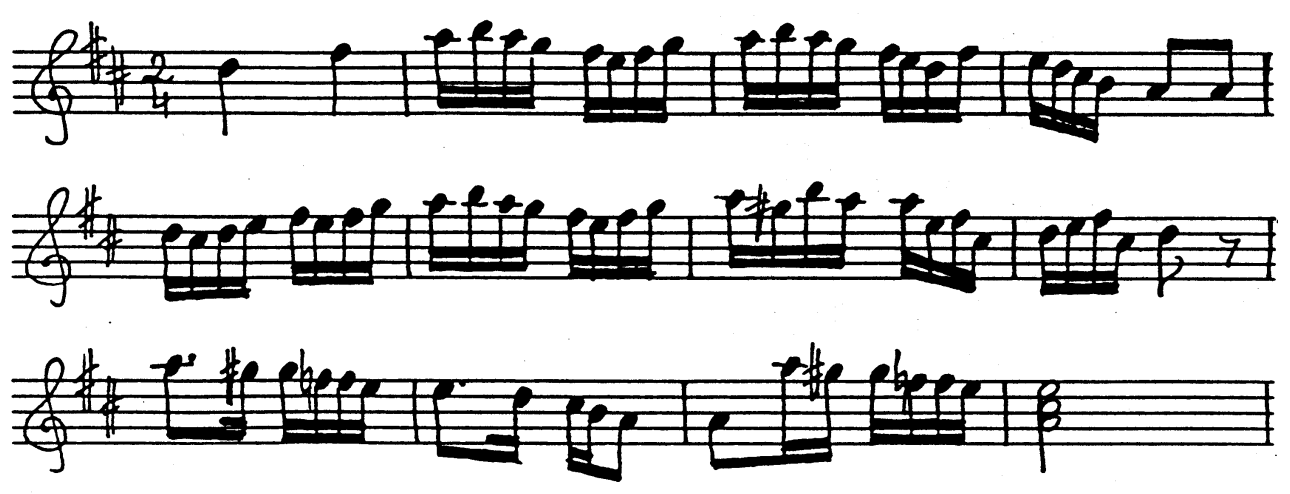

Example 3: Bihari: Moderato Andante, Trio no. 2, bars 1-12

the mature stock. Bihari's Lassú Magyar [Slow Hungarian Dance] in d minor takes different shapes in the 3rd booklet (dance no. 2) of the Nemzeti Magyar Táncok and in the 1st booklet (no.1) of Magyar Nóták Veszprém Vármegyéböl. Underlying the difference is the fact that Bihari was musically illiterate so the notations were made by others. In other cases, the variability of some pieces can be attributed to the fact that the composers drew on an earlier stratum of the repertory which was naturally characterized by variation. No. 32 of the 5th volume of Magyar Nóták Veszprém Vármegyéböl and no. 73 of its volume 9 (one by Bihari, the other anonymous), as well as no. 2 of volume 2 of Pannónia (János Árvay) can probably be retraced to one and the same early verbunkos movement whose first notation is known from the finale of Haydn's Piano trio in G major (Hob. XV:25). It is not known if it had an earlier verbunkos source or later verbunkos composers adopted its rondo theme as typical early verbunkos material. It is clear that the published movements were based on various instrumental figurations similarly to Haydn's theme and to the majority of the early verbunkos repertory, hence suitable to appear in diverse variants. In this later material, however, the phenomenon is downright isolated, not simply exceptional. The overwhelming majority of the pieces assumed quite individual characters: a Csermák, Lavotta or Bihari work (despite the incidentalities of notation in the latter's) is a genuine composition. Even less outstanding composers began to use more diverse compositorial tools.

Stylistic enrichment was particularly conspicuous in rhythm, first of all in the slow pieces where the tempo allowed for passages which could 
equally rely on the Gypsy musicians' freely ornamental performing style and on certain elements of western music. The typical ornamentation of the slow movements of Beethoven sonatas directly appear in some richly embellished slow Hungarian pieces. This connection cannot be accidental; with the spread of the verbunkos the performers of fashionable Hungarian music also playing it abroad got increasingly into situations in which they received so-far unknown musical impulses. The most apt example is that of Bihari who is known to have made a guest appearance in Vienna around $1800 .{ }^{17}$ Further information is provided by Mátray who noted that the Gypsy virtuoso frequently visited the imperial capital and stayed there during the Wiener Kongress as well. ${ }^{18}$ Major's publication reveals that according to Gyula Káldy, even Beethoven heard Bihari play. ${ }^{19}$ Although there is no information about Bihari knowing any Beethoven work, his verbunkos pieces suggest that he had heard some Beethoven music, if not in Vienna then in Hungary where the composer's work was not quite unknown at that time. It is indubitable that the verbunkos was susceptible to influences from the beginning, adopting several elements from western music, so it must have borrowed newer western models as well. This is partly what explains its rhythmic versatility, which is one of the most conspicuous features of the mature verbunkos style compared to its initial phase. The other difference is in the handling of the melody also becoming freer and more diversified. Unexpected turns and great leaps appear frequently. The tonal range also increased and sweeping melodic lines began to replace the early pieces of modest undulation.

In connection with rhythmic and melodic factors, the notation alluding to virtuosic performance also rose in significance. Gracing elements became more frequent, including not only ornaments of a few notes but also coloraturas similar to longer violin flourishes. Cimbalom-like passages and other instrumental stylizations also crop up as in no. 4 of the 2 nd volume of the Pannónia set: Egygy Somogyi birkás furullya Nótája [The flute tune of a shepherd of Somogy], with ornamenting and accompanying figures evoking the flute and bagpipe or the düvö accompaniment ${ }^{20}$ in dance no. 1 by Csermák in the Magyar Nemzeti Tánczok.

17 Bónis: Beethoven, p. 32.

18 Mátray: Bihari János, p. 291.

19 Major: Bihari,p. 16.

20 Düvö: Hungarian folk string orchestras' manner of playing in which the accompanying parts play two basic values (i.e. two crotchets or quavers) legato with one bow and put the accent on the second one. 
Chordal treatment is also more diverse, although simple harmony based on the I-IV-V degrees is still frequent. Altered chords (e.g. diminished seventh), chromatic scales in the melody, unexpected changes of key at times may also crop up. The most popular of these are third-related changes, probably a recent western effect in verbunkos music, but other changes - not common in western music - were also used. These, however, are very rare and not typical of the whole stock; they characterize some composers, first of all Csermák, in whom these features are sometimes incidental, sometimes original, and lend additional colour to the texture, but they do not fundamentally influence the harmonic world of the verbunkos.

The structure of the pieces remained regular in most cases, being built of 4-, 8-, etc. bar units or periods. The number of movements that are asymmetrically articulated, i.e. alternating 3-, 5-, 7-, 9- etc. bar units with each other or with patterns of regular even-numbered bars considerably increased. Since this feature is demonstrable in several composers and relatively frequently, it can be contended that, unlike in harmony where unusual turns were marginal, these irregular devices became an important trait of mature verbunkos style. It is an interesting paradox that these structural solutions are also individual as are the chordal ones, for asymmetrical phrases can be combined in an endless number, yet they could become typical.

As for the formal characteristics of mature verbunkos, they had undergone various changes, although the typical form of enumerating thematically independent periods remained decisive. The ABA forms which were exceptional in the early period became however more and more frequent, producing far more unified compositions than the earlier enumerative works. This unity is little asserted in some Hungarian dances by Csermák (e.g. Sechs National Hungarische Romanzen Werbunk, nos 3, 4, 5) in which the composer only indicated the return by recapitulating a massively abbreviated or transformed section. The "reprise" may only be a quotation of one or two bars in length from the "main part", followed by another new musical section with little or no connection to the "main section". In these cases no regular form is created. Though itself intriguing, this phenomenon remained isolated in the verbunkos repertory as did the individual chordal ideas also in Csermák's output which can be attributed to the composer's invention and attraction to special effect. As for the whole of the repertory, the tendencies influencing the entire stock are more significant. The main formal characteristic of the mature verbunkos is the increase in compositions in which pieces 
of various tempo and character are arranged into larger structural units. The need to have a verbunkos piece containing several dance movements was not only seen in the increase in the number of such compositions but also in the efforts of editors of such publications in compiling various many-movement "works" often from pieces of different composers.

Szabolcsi defined this gradually emerging many-part construction as an important lineament of the verbunkos. ${ }^{21}$ Its simplest variant is the two-dance lassú-friss (slow-fast) type which may have a slow movement followed by the Figura section, or may be combined with a trio in which the main section is slow and the trio is fast, with the slow part returning, when the form is a regular trio form. In a more intricate overall construction built from three, four or more sections the gradually accelerating movements following the slow main section may be called Friss, Figura or Trio. In such cases, the term Trio merely denotes a dance movement in a suite-like form, followed not by the main section but by the next Trio or Figura. The wavering terminology is well illustrated by the first composition in Lavotta's Verbunkós Noták [Verbunkos Tunes] published in 1814 in which the main section is followed by an Attacca Subito Trio movement and a Figura o Trio II. Such cases however make one wonder what indeed the naming of the movements might have meant and how they were actually performed. If some sections did return within the overall form, then we have the rudiments of the cyclical form type whose stabilization is dated by Szabolcsi to the mid-1840s and which developed into a gradually expanding multi-part construction via different reprises, repetitions, variations. ${ }^{22}$

It is a fundamental precondition for the many-part form to have sharply distinct tempo and character types included in the repertory. As against the early verbunkos stock the slow and friss dances were not stylistically sharply differentiated being based on the given patterns (although in performance, there must have been some difference), these two types came to be far more markedly differentiated in the later phase. Further differentiation into distinct subtypes as vehicles of different intonations was chiefly to appear in the slow dances of the two basic types.

The first subgroup of the slow dances is the "tight, giusto" type. The tempo is restrained and strictly regular: that applies to both more sweeping and vigorous movements and dignified Adagios, the latter "stately and elab-

21 Szabolcsi: Romantikus müzene, p. 125.

22 Iidem, p. 126. 
orate". The character of the type is principally determined by the tight rhythm often like gestures. Dotted rhythms of semiquavers came to a head which lend the more dance-like pieces a noble deportment, and to more serious pieces a heroic, sometimes pathetic character. Although the type is characterized mainly by dotted rhythms, several other differentiated rhythmic elements can also be gleaned. The pathetic character goes best with a minor key, but even major pieces can evoke similar intonations if the rhythm is pregnant enough. The examples illustrate the "stately and elaborate" and prancing "tight, giusto" types (Examples 4, 5). The second subtype is the "pliable, cantabile" type. Its gestures are less sharp, its tempo is moderately slow and rhythmically less differentiated. Its character is far calmer, as if it were the "feminine" contrast to the "tight, giusto" type; the subtle smooth set of movements underlying the dances also confirm that. The type is usually tied to major keys and contains several tuneful features, often passages of thirds (Example 6). A rarer but also characteristic subtype is the "free, rubato" type, the stylized manifestation of the improvisatory solo instrumental performance of Gypsy musicians. That is the most diverse type rhythmically, containing innumerable ornaments in small notes. It is characterized by long runs and long pauses, composed agogic accents. Its rhapsodic, whimsical character comes from its improvisatory nature. The intonation is sometimes passsionate and more frequently lamentoso (Example 7). The above types may apply to whole movements, but may also be mixed within a movement, producing mixed types.

The friss pieces are more unified and homogeneous than the slow ones; various character types are harder to differentiate among them. The rapid verbunkos movements, whose thematic-motivic contents deviated far from the compositions rooted in the pattern set of the early period, are rhythmically more complex, with more contrast and effects such as the unexpected confrontation of short and long note values. Their melodic contours are also more daring. Some require virtuosic performing skills; the most elaborate ones separate from the rhythmically differentiated movements by their perpetuum mobile-like texture based on an even progression of semiquavers. Besides enhanced virtuosity, these pieces are also typically energetic, lending a truly "fiery" character to most fast dances (Example 8).

The stylistic enrichment in the repertory of mature verbunkos music, the aspiration after more complex forms and the appearance of various typical atmospheric intonations prove that from the functional use of the early 

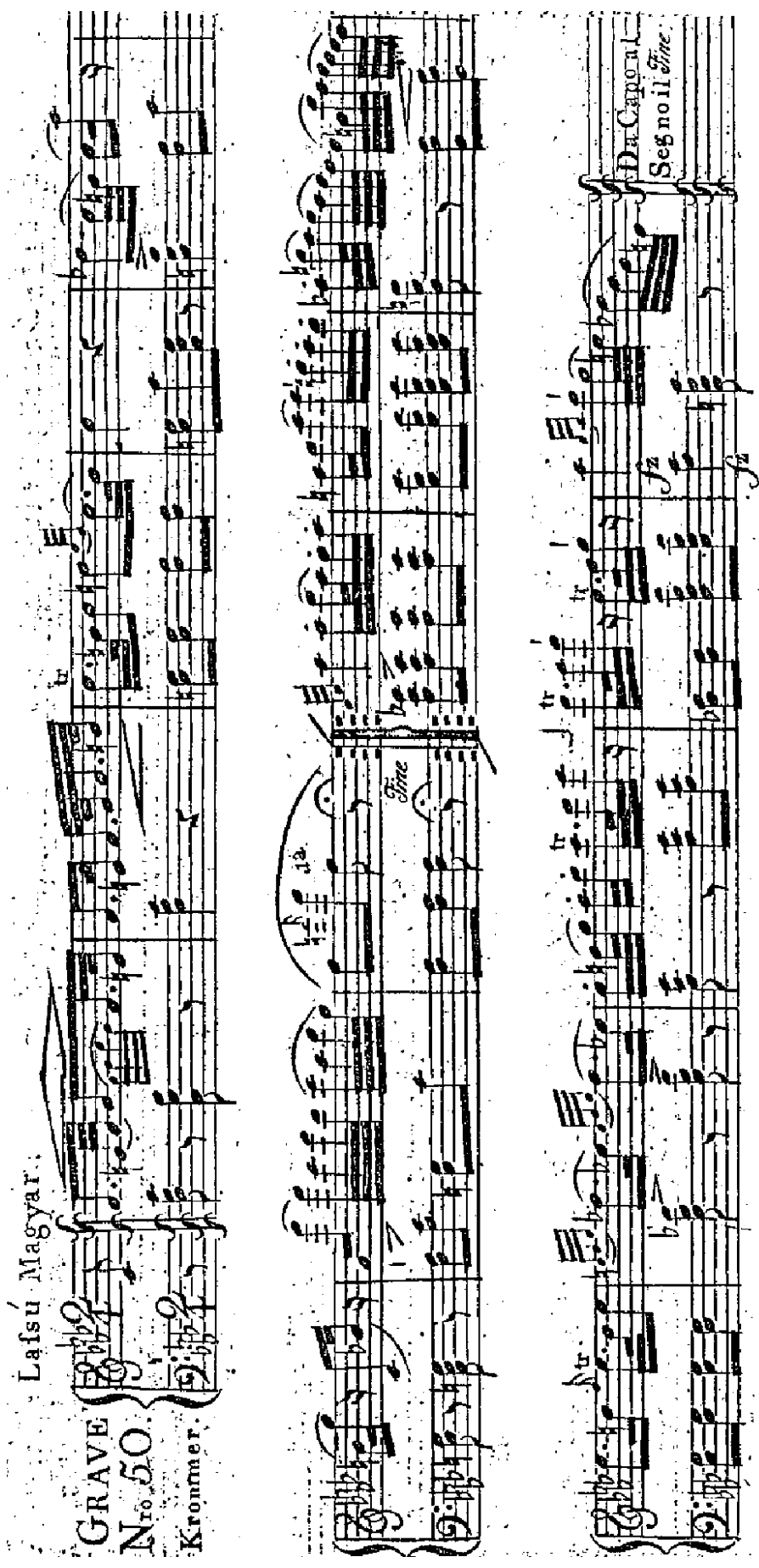

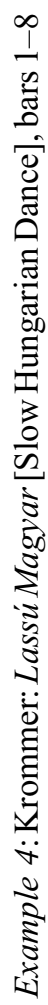




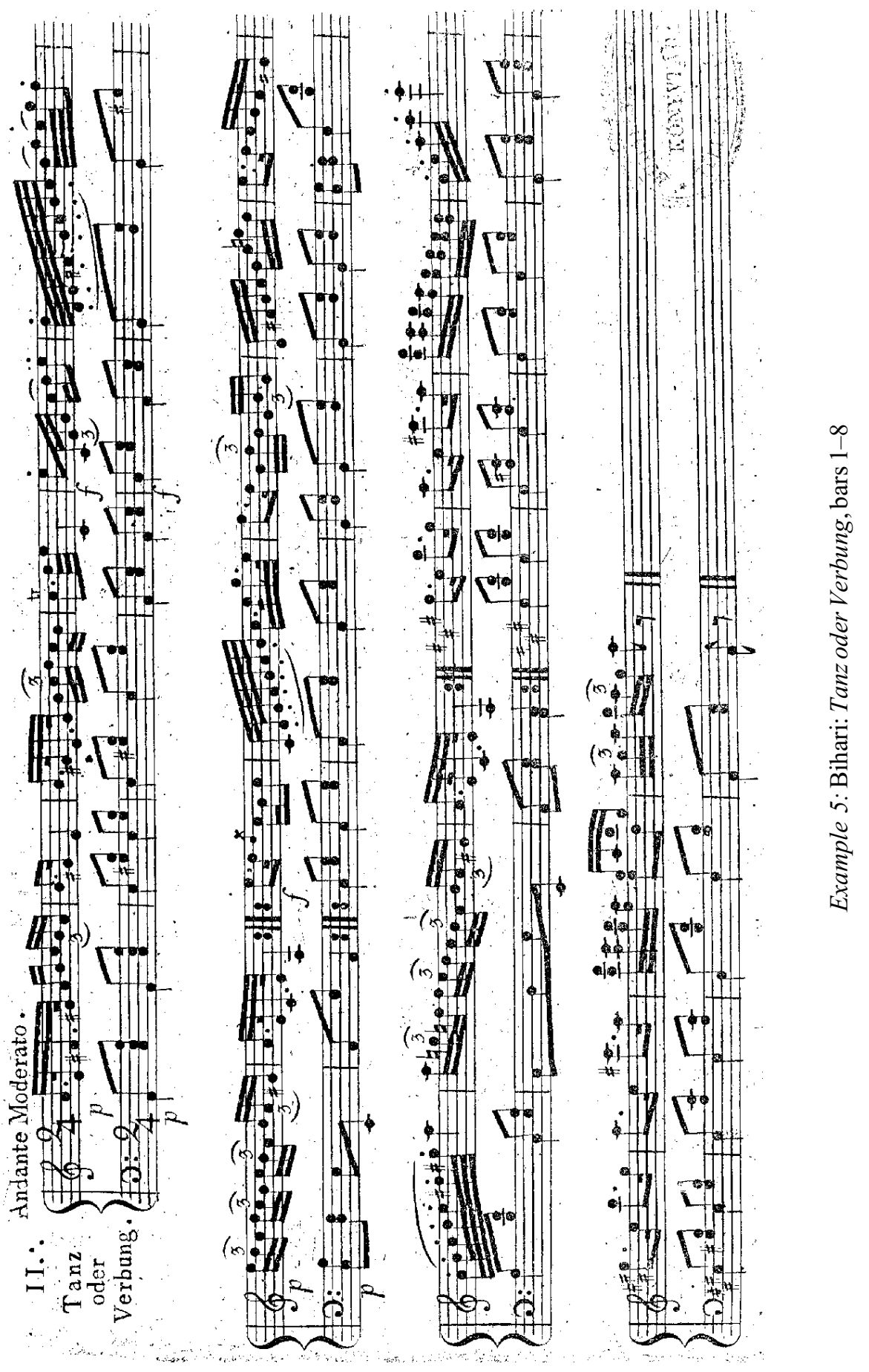




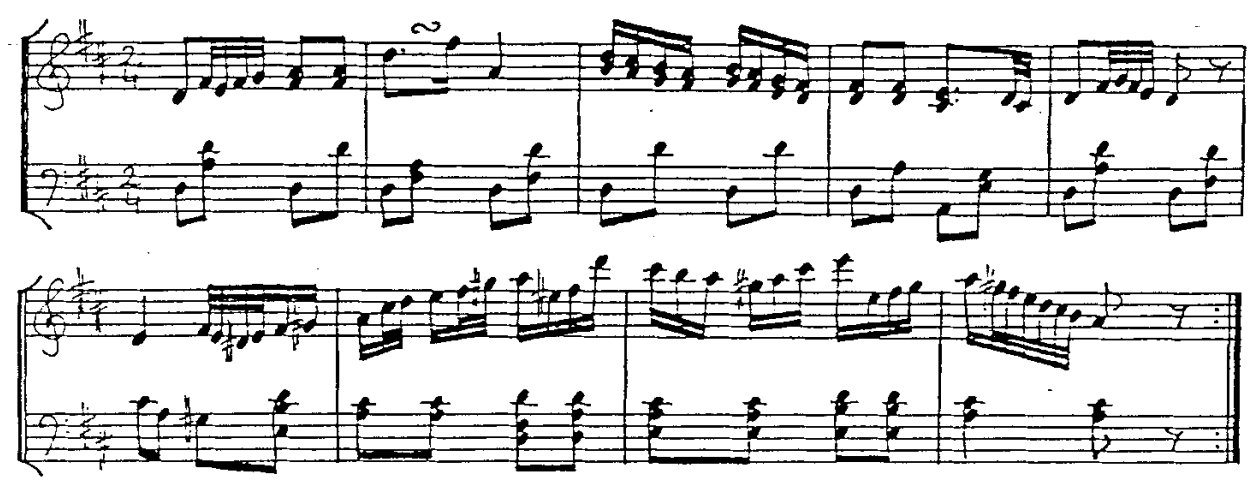

Example 6: Csermák: Tempo di Verbunk, bars 1-9

period the verbunkos stepped up to a higher level of art music, getting stylized, in the early 19th century. That holds true in spite of the fact that at that time also, it fulfilled a dual role: on the one hand, it became instrumental art music, and on the other, it was simply - though less frequently - entertaining dance music. The following lines by Gábor Mátray refer to the latter: “János Bihari. Famous Gypsy violinist of Pest and composer of Hung. Tunes, some of which have also been published. He was the performer of Hungarian tunes at several coronation ceremonies at the court balls, for example in Pozson [now: Bratislava] in 1825." ${ }^{23}$ Since the dance let itself be felt in most pieces, the verbunkos remained suitable to function as dance music. But, at the same time, it superseded this role becoming enriched with several elements that, when composed by able musicians, pointed beyond the repertory created for easy domestic music-making, producing eventually a rich stock of art music which could rightly arouse the interest of 19th century western composers and stimulate the emergence of style hongrois.

\section{Classicism and Style Hongrois}

It was an important precedent to the 19th century efflorescence of style hongrois that composers of the last third of the 18th and beginning of the 19th century wished to add special hues to their musical language via elements alien to that idiom. One form of this drive was the Turkish interest. The attraction of classicism to folk idioms on the one hand and exotic characters on the other also generated an interest in Hungarian music, especially

23 Mátray: Muzsikának, pp. 148-149. 

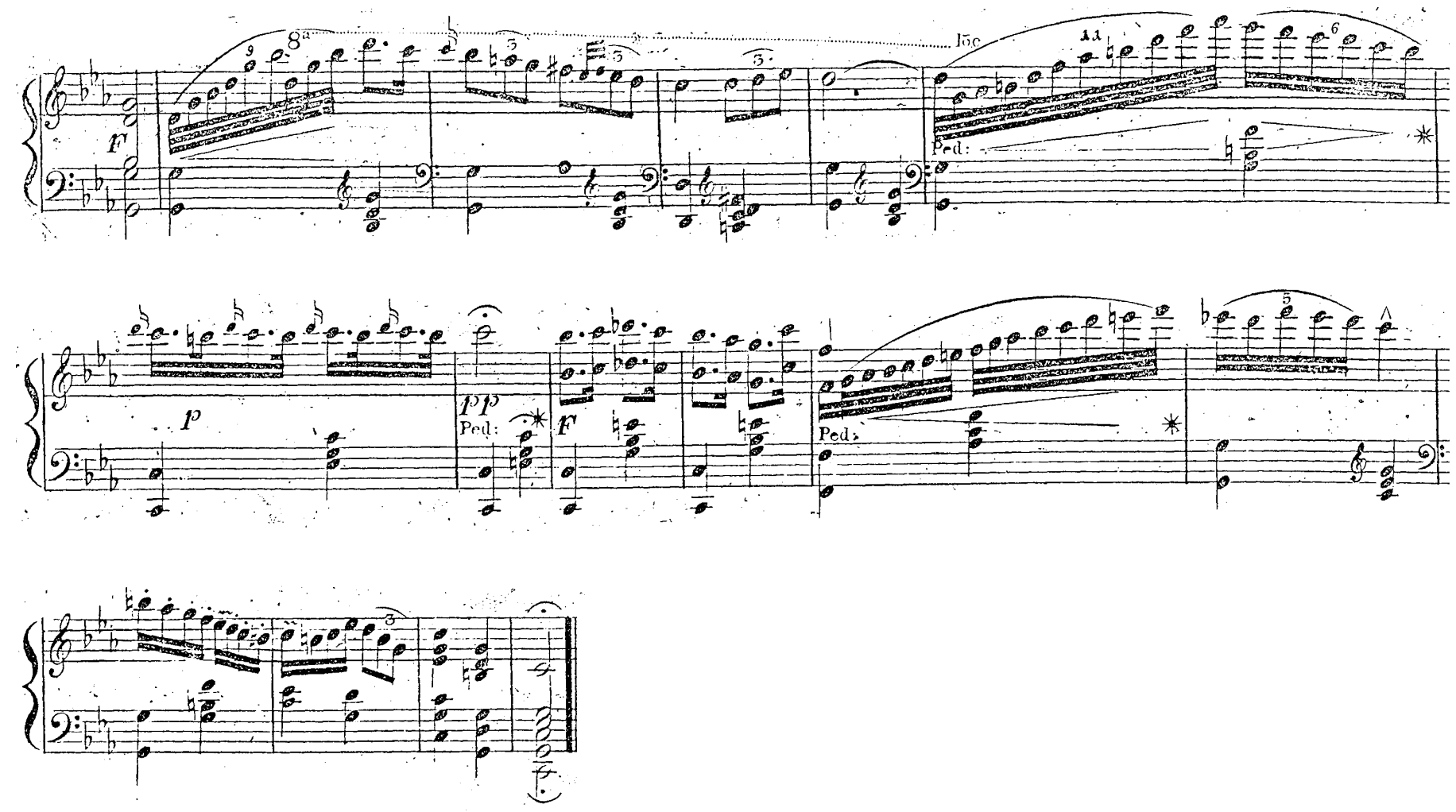

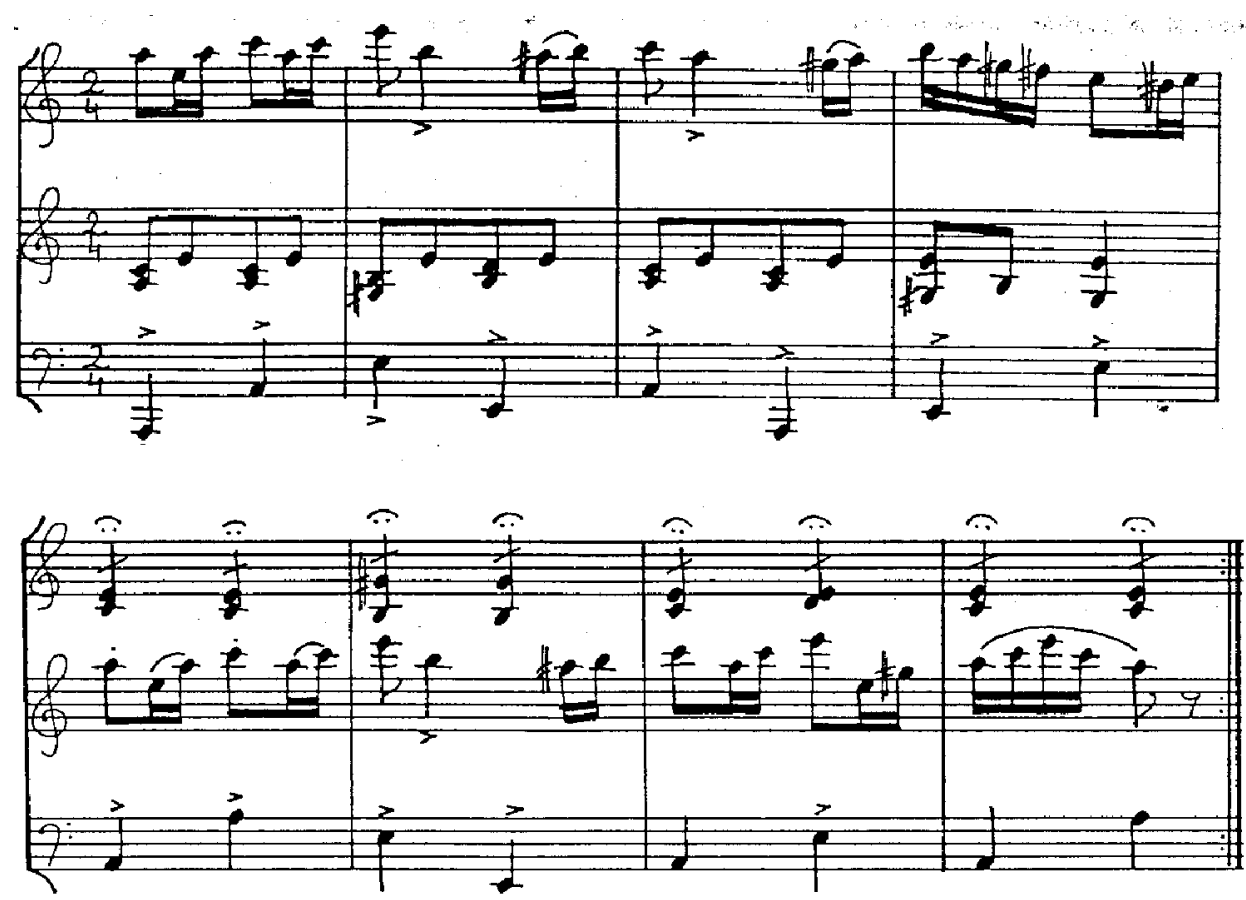

Example 8: Bihari: Allegro, bars 1-8

in composers having some contact with Hungary or Hungarians and through that, with verbunkos music.

Maybe that is why this interest remained marginal with Mozart of the three great figures of classicism. Only two of his works allow some Hungarian influence to be detected. One is the Violin concerto in A major (K 219) the third movement of which contains the well-known Hungarian-Turkish style episode in a minor in the violin solo of which Szabolcsi appears to have detected the very first notated verbunkos tune. ${ }^{24}$ The other is the String quartet in F major (K 590) in the finale of which Istvánffy, in the wake of Szabolcsi's observations, demonstrates Hungarian elements at the end of the exposition and the reprise, in a figurative section with accompaniment of bagpipe bass and syncopation. ${ }^{25}$

In Haydn's and Beethoven's music the Hungarian influence plays a more significant role: both composers had experiences that stimulated the development of this influence. Haydn was in the service of Nikolaus Esterházy in Hungary for several decades, thus he must have had first-hand know-

24 Szabolcsi: $M Z K$, p. 59.

25 Istvánffy: All'Ongarese, p. 110. 
ledge of the emerging and increasingly crystallized new verbunkos music. It can also be documented that he had contemporaneous verbunkos publications such as a collection entitled Ungarische Nationaltänze, mentioned in the 1858 inventory of Prince Esterházy. ${ }^{26}$ Szabolcsi also stresses that Haydn must have had a lot of handwritten sources at his disposal. ${ }^{27}$ All this may allow the assumption that Haydn was seriously interested in Hungarian music.

Beethoven did not live in Hungary for a long time but he had close connections. That does not only apply to the noble families he was befriended by (e.g. the Brunszvik, Erdődy and Apponyi families) who may have aroused his interest in Hungarian music, as Istvánffy argues, ${ }^{28}$ but also to professional musicians. The most important of them was Bihari who visited Vienna several times and whose performance must have been heard by Beethoven. That he knew some of his compositions is proven by a melody of his being treated in the incidental music König Stephan (op.117). ${ }^{29}$ (Major discovered this tune in János Keresztély Hunyadi's National ungarische für den Csakan allein. Mátray attributed the verbunkos tunes in the volume to Bihari back in 1854. Major also makes reference to the question of the authorship as raised by Mátray. $)^{30}$

In addition, Beethoven may have come into contact with the living practice of the verbunkos when he visited Hungary privately or for concerts; research literature mentions several and can document three such trips: one to Pozsony in 1796, another to Buda in 1800 in the course of which Beethoven gave concerts, and a visit to Kismarton in $1807 .{ }^{31}$ Nor can the fact be ignored that until the upsurge of Hungarian music publication in the early $1820 \mathrm{~s},{ }^{32}$ verbunkos publications were almost exclusively released by Viennese publishers. Thus, Beethoven had the chance to satisfy his interest in verbunkos music even in Vienna.

The influence of this music can be discerned in the music of both Haydn and Beethoven. The differences in the composers' dispositions and the changes in the repertory on which they drew, however, account for the differences in their use.

\footnotetext{
26 Szabolcsi: Haydn, p. 633.

27 Idem.

28 Istvánffy: All'Ongarese, p. 110.

29 Bónis: Beethoven, p. 32.

30 Major: Fejezetek, p. 60.

31 Bónis: Beethoven, p. 31.

32 Papp: Verbunkoskiadványok, p. 253.
} 
Haydn's Hungarian features are mainly direct references to the basic traits of the style so the Hungarian influence is most direct in his music. His all'ongarese movements and Hungarian themes are all stylistic games: through them, Haydn proved that he could use a foreign musical language as perfectly as his own vernacular. Within his oeuvre these instances have no more function than to represent brilliantly this compositorial game. That, of course, required a perfect knowledge of the style, which is alike verified by the relevant aspects of his biography and the works including the Hungarian sections. These sections are partly characterized by the consistent use of well-known verbunkos patterns and partly by effects that refer to the characteristic performing style of the verbunkos.

The possible verbunkos contacts of the rondo theme in the finale of the Piano trio in $G$ major have been mentioned; the episodes prove even more securely that Haydn relied firmly on the original sources. The figures with progressive anticipations determining the first period of the first $\mathrm{G}$ major episode are just as frequent in verbunkos pieces of the time as are the cadential formulae in the second period. Besides, such effects as the deliberately simple harmonic pedal accompaniment or the tune with alla zoppa rhythm all reinforce the impression that the music in question may be any dance movement in an early verbunkos collection. The more so as the two periods constituting the first episode are linked as are most verbunkos periods in the early phase: set side by side without any thematic connection. Since the second $g$ minor episode naturally with completely new material is placed immediately after the first, this principle of enumeration is asserted further. No detailed analysis of the patterns applied to the new episode is necessary since the tune has a concrete verbunkos analogy ${ }^{33}$ (Example 9). That also applies to the theme of the third episode whose Hungarian character is also reinforced by the syncopated accompaniment. Although the verbunkos collection was published later than the composition of the Haydn work, it is not impossible that Haydn knew the tunes or their variants from a source unknown to us. At any rate, it is striking how precisely the tiniest motivic detail and rhythmic construction tally with the elements of verbunkos music of the time so much so that they could hardly be separated from it. Instead of massive stylization, Haydn showed up the style in its natural form, letting it exert its influence directly.

${ }^{33}$ See Papp's notes about the 6th piece of the 1st volume of 22 Originelle ungarische Nationaltänze. Papp: Hungarian Dances, p. 339. 
[129]
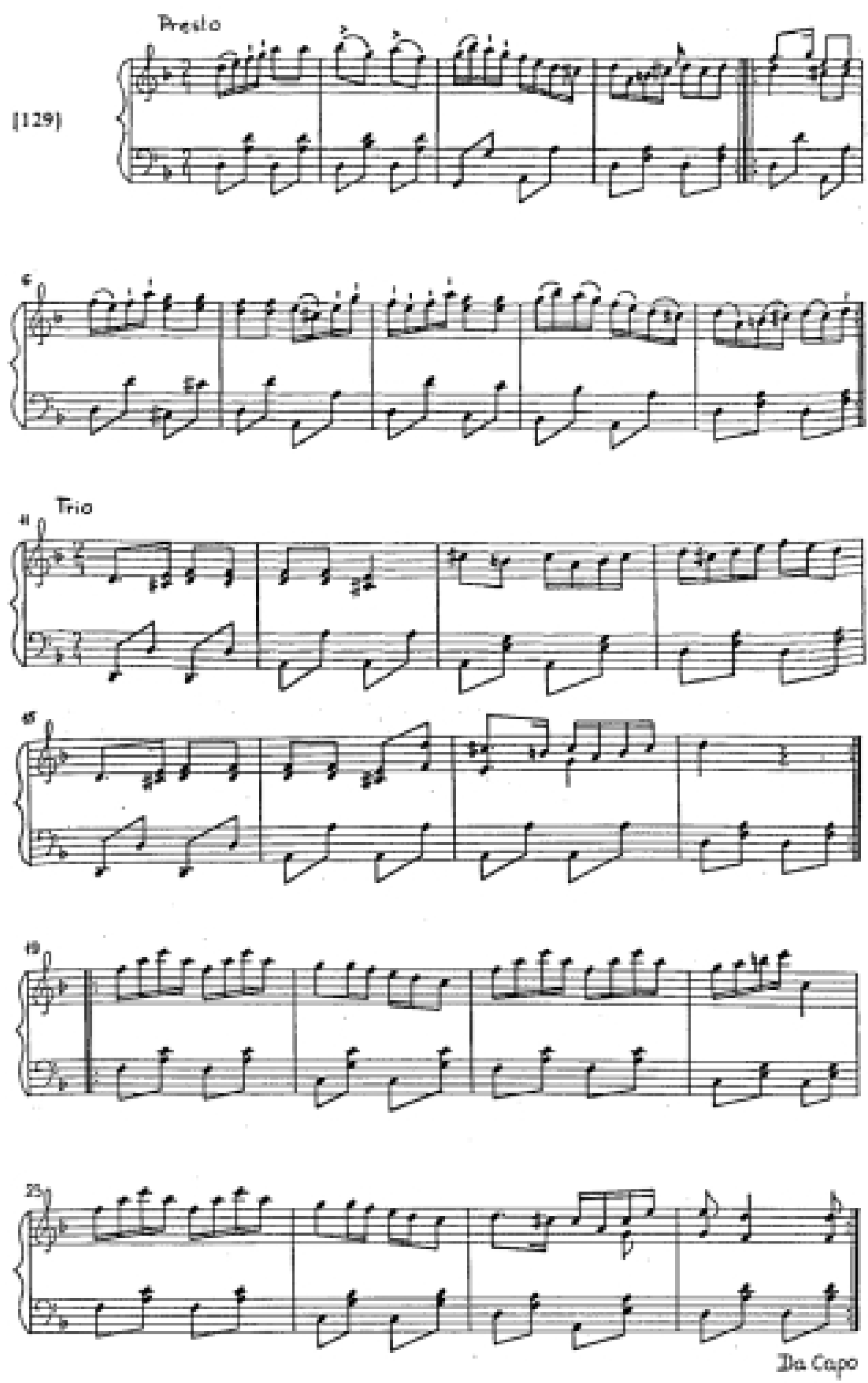

Example 9: 22 originelle ungarische Nationaltänze, Heft 1, No. 6 
This statement also holds true of works in which no concrete verbunkos tune is treated. A case in point is the last movement of the Piano concerto in $D$ major (Hob. XVIII:11) whose typical figurations and motif repeating technique draw it very close stylistically to the simple melody types of the verbunkos. This can also be said of works in which the Hungarian influence is restricted only to a theme or short section. In the Hungarian passages of the fourth movement of the String quartet in D major op. 20, no. 4 (Hob. III:34, bars 43-45 and 119-121), Haydn applied a sequence of turn motifs equipped with an alla zoppa accompaniment and with appoggiaturas. This texture clearly refers to the verbunkos material. The main theme of the finale of the $d$ minor quartet op. 76, no. 2 (Hob. III:76) contains several elements in close connection with peculiarities of the typical verbunkos tunes. The rhythmic pattern outlines a customary formula of the early verbunkos with a regular appearance of syncopations every two bars. Motivically, the closing of the theme is noteworthy marking the contour of a closing pattern with a turn motif. In addition to the rhythmic and motivic features, the simple structure of repeated two-bar motifs in the theme also deserves attention.

To sum up, it can be contended that for Haydn the basic stylistic features of the repertory were the figurative richness, the set of patterns fixed by the typical instrumental figurations and the atmospheric elements filtered from live performance which he mainly adapted to the art music context unchanged or with slight modifications only. It must be stressed that his sources were the early verbunkos pieces, that is, a verbunkos repertory approximately contemporaneous with Haydn's Hungaricisms. Its figurative variability and typical idioms fitted well the movement type in which they nearly without exception crop up: the spinning rapid finales in rondo form.

Usually two examples are cited in research literature devoted to the Hungarian influences in Haydn's works that seem to contradict the abovesaid. It was Szabolcsi who first suggested that the second movement of the $D$ major sonata (Hob. XVI:37) and the first movement of the Piano trio in $g$ minor (Hob. XVIII:1) represent a type that anticipates the later verbunkos music stylized into art music. ${ }^{34}$ Istvánffy also adopted this theory. ${ }^{35}$ Both are slow movements and both have a conspicuously differentiated rhythmic texture, with an accentuated role of dotted rhythms - and this might perhaps suggest that they are prototypes of the slow type of verbunkos. That, how-

34 Szabolcsi: Haydn, p. 633.

35 Istvánffy: All'Ongarese, pp. 86-88. 
ever, is not tenable; the analogy between the slow movements of mature verbunkos and the Haydn movements in question is illusory. In his study of Haydn's sonatas László Somfai notes that the Largo of the D major sonata, similarly to some other slow movements, is a baroque exercise in style: a piece in French ouverture style. ${ }^{36}$ The baroque-like suspensions and the use of triple time preclude the influence of the verbunkos. The first movement of the $\mathrm{g}$ minor trio is a similarly stylized baroque piece, its powerful dotting also revealing the influence of the ouverture. These movements therefore do not belong to Haydn's Hungarian style and do not tint the picture outlined by the typical rondo finales.

Among Beethoven's works with Hungarian references there is but a single piece that continues along the path signposted by Haydn. His Alla ingherese, quasi un capriccio (op.129) (i) $^{37}$ a swift rondo movement similar to Haydn's most Hungarian-like pieces, with the figurative elements playing the primary role. The theme itself is built from various figurations and the repetition of few-note motifs hence its structure assumes a folk-like simplicity. The stylistic play becomes indeed playfulness, if not parody. Perhaps because Beethoven did not take this game so seriously as Haydn did, the Hungarian character of his work is less unambiguous. The motif-repeating structure of the theme does remind one of the verbunkos in some way, the motifs themselves, however, do not display the most typical patterns. Instead of the Haydnian principle "true because it's like that" we have the principle of "it seems as if". The Hungarian influence is even more vague in the episodes, especially at points where - as the musical process develops - the Beethovenian virtuosity, his play with the space and potentialities of the piano comes to the fore. The first episode resists definition as Hungaricism because its figurations may just as well be Turkish as Hungarian, reminding one most strongly of Mozart's Alla turca in his A major sonata (K. 331/330i), especially its f sharp minor episode. The mixing of the "Hungarian" and "Turkish" elements warns that in the eye of western composers various exotic features did not become distinct and it was not always clear which moment of the music was taken for Hungarian and which for Turkish exoticism.

The parodically reinterpreting stylistic play of Alla ingherese cannot, however, be reckoned among Beethoven's typical Hungaricisms. Far greater relevance is borne in the development of style hongrois by the works

36 Somfai: Haydn zongoraszonátái, p. 258.

37 The title appears in the critical edition as Alla ingharese, in Kinsky-Halm as Alla ingherese. 
in which the Hungarian episodes carry new intonations, or perhaps extra musical concepts that were so far alien to the style. The change is well exemplified by the g minor episode of the final movement of the "Eroica" symphony (op. 55) which inspired József Ujfalussy to write: "The Hungarian character assumed a heroic aura in Beethoven's music around 1800." 38 This heroic aura derives first of all from the dotted rhythm of the episode which compares the theme to the revolutionary-heroic French march. ${ }^{39}$ While, on the one hand, the episode draws on the march-themes - as frequently occurs in Beethoven, with the same heroic character e.g. in the finale of the Ninth Symphony (op. 125), on the other hand it is highly likely that a typical subgroup of the transforming, stylizing verbunkos repertoire also contributes to the heroic intonation. That is the "tight, giusto" type which is also characterized by the preponderance of dotted rhythm and the heroic character defined by Ujfalussy. Although in the verbunkos repertory this type is coupled with the slow tempo, Beethoven eliminated this problem by augmenting the semiquaver dotting customary in the verbunkos. Apart from this, it is conspicuous how typical the melodic turns Beethoven uses are of the verbunkos ( $E x$ ample 10). Hence the reference of the theme to the verbunkos is obvious. With this episode, Beethoven opened new possibilities in the history of Hungarian style: through verbunkos-rooted intonation, the Hungarian elements may assume new connotations.

In the second theme of the finale of the Seventh Symphony (op. 92) and the Hungarian episode of the third movement of the "Appassionata" Sonata (op. 57, bars 316-334) Beethoven reached forms of expression that were unknown to composers using style hongrois so far and which may be related to the fact that the composer possibly knew the performing art of one of the greatest virtuosos of verbunkos music, Bihari. In the relevant sections of both the symphony and the sonata, a state of passion heated to bursting point appears and Beethoven found only the gestures of verbunkos music powerful enough to convey this state. Especially noteworthy is the episode in question in the Appassionata: the composer elicited the emotional effect via the contrast of minims accented by the typical upbeat and aprajázás intensified to demoniac dimension by the virtuosic, repeated bar pairs.

38 Ujfalussy: Beethoven III, p. 13.

${ }^{39}$ Idem, p. 12. 


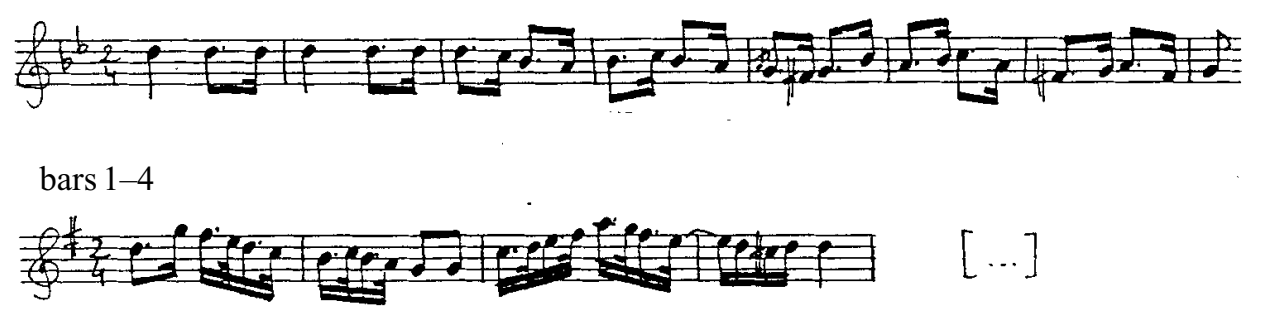

bars 9-12
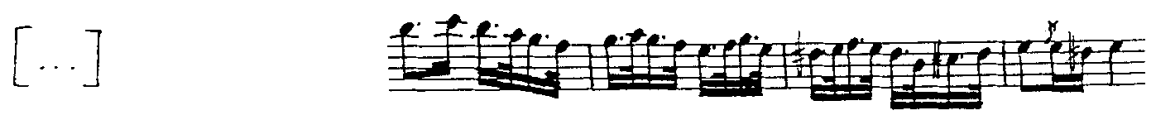

Example 10: Beethoven: Symphony in Eflat major (Eroica), movement 4, bars 211-218 Tost: Douze Nouvelles Danses Hongroises, no. 4, bars 1-4, 9-12

Thus, Beethoven realized that Hungaricisms were suited to more than just exotic colouration and could express more profound musical meanings, thus designating a new trend in the development of style hongrois.

\section{Carl Maria von Weber and style hongrois. Biographic Data, Works}

It is hard to declare that Weber, whose output includes style hongrois at a place that is not negligible, even though not predominant, had any tight or close contacts with Hungary, Hungarian musicians or Hungarian music. His lifepath, however, shows a real travelling artist who visited a great many places and absorbed all the influences that reached him. He got accustomed to the itinerant way of life in his early childhood and continued it into adulthood. He frequently changed his stations, in search for the place and position best fitting his artistic goals. He even travelled much when his work tied him to a town. He gave many concerts; that was one reason for his extensive travels. Apart from the innumerable German towns where he stayed for various periods of time, he reached Upper Silezia in today's Poland, held a conducting job in Prague, toured Switzerland, Vienna, and his last concert tour led him to London. ${ }^{40}$

Though the eastern parts of Europe were not quite unknown to him, even the most detailed biographies fail to mention any reference to a trip to Hungary or any Hungarian contact. There is a single piece of Hungary-

40 As for the detailed description of his career and journeys see: Zschacke: Weber. 
related information about Weber. Baron Frigyes Podmaniczky wrote in his diary: "My father frequently communicated with Dresden, not only because he cherished a close relationship with the parents and siblings of his wife, but also because he was friendly with the world famous composer of 'Der Freischütz', Carl Maria Weber, and corresponded with him. Owing to this friendship, when the opera 'Pretiosa' was being composed, my father sent Weber several Hungarian tunes by Bihari; these tunes had been notated by the music teacher of my sisters after Bihari's performance in Aszód and arranged for the piano." ${ }^{41}$ Major does not find it probable that Weber made use of the Bihari tunes in Preciosa, since in his view some slight Hungarian character can only be detected in the Gypsy chorus of the second act. ${ }^{42}$

It is known that the composer searched for "original" sources when composing other exotic or fairy tale operas. The ouverture and six numbers of the incidental music for Schiller's Turandot are based on Chinese tunes taken from Rousseau's Dictionnaire de musique, ${ }^{43}$ and he enriched the musical material of Oberon with motifs of oriental dances he had discovered. ${ }^{44}$ It is a moot question how originally Chinese or oriental his sources were. The fact of searching for genuine sources, however, stresses Weber's attraction to the exotic, which was not only apparent in his stage works but also in his instrumental pieces. The works containing Hungarian or "Gypsy-like" thematic materials, the latter often being identified with the former in western culture - Andante e rondo ungarese (1809, op. 35), the movement Alla Zingara of Huit pieces, a series for four hands (1818-19, op. 60), and Sieben Variationen über ein Zigeunerlied (op. 55) fit into the series of works entitled Polacca, Alla Polacca, Carattere Espagnuolo, Espagnuole, Air russe, Air polonaise. In Weber's music, therefore, the Hungarian colour is only one possibility to express exotic contents.

\section{The Exotic in Weber's Music}

The movement titles listed above reveal that the exotic was apparently most diverse in Weber's music. This diversity, however, often becomes commingled; the movements, in view of their musical material, do not always differ from each other as clear national types. So it seems that apart from a sketchy indication of musical features commonly associated with a nation, Weber's

\footnotetext{
41 Podmaniczky: Napló I, p. 60.

42 Major: Bihari, p. 18

43 Spitta-Warrack: Weber, p. 255.

44 Idem, p. 252.
} 
ambition was to have an undefined exoticism among his musical devices. That is why he is often cavalier in his handling of the characteristics that are sometimes clearly recognizable and sometimes questionable.

These problems are well reflected by the incidental music he composed for Pius Alexander Wolff's Preciosa in which a Spanish-Gypsy milieu is required by the plot. The play is about a Gypsy girl, Preciosa, whom a young nobleman falls in love with and joins the wondering Gypsies for. After the tribulations of the lovers, of course the lieto fine cannot be avoided: Preciosa turns out to be a young noble lady who got into the Gypsy company that brought her up as a child. ${ }^{45}$ The story abounds in unusual, romantic settings allowing for exotic music representation.

The first two numbers of the first act introduces the milieu: Zigeunermarsch and Chor und Tanz der Zigeuner. In his biography of Weber, Günter Zschacke cites the composer's words about Zigeunermarsch, claiming that the march was based on an original tune. ${ }^{46}$ Nothing else can be known about the source, nor does Major's commentary mentioned above confirm that the movement might have Hungarian references. Neither is it clear whether the Zigeuner name hides Hungarian elements or character, although Bellman deems the march a typical manifestation of style hongrois. ${ }^{47} \mathrm{He}$ also presumes that underlying it was music performed by Hungarian Gypsies. ${ }^{48}$ In spite of all that, the Hungarian character of the movement is disputable. Its simple, perhaps deliberately "primitive" structure of four-bar phrases no doubt evoke the simplest verbunkos tunes, especially because there is no thematic connection between the phrases. The motifs, however, hardly convince the analyst of their Hungarian character. In the first four-bar section it is maybe the cadence and a few notes with appoggiaturas that lend it some Hungarian colour. It is, however, doubtful that these few moments are sufficient to verify that the movement is in style hongrois. Although the dotted rhythm is a decisive lineament of the verbunkos, the simple dotting in the theme-head is far more directly a reference to the march character than to verbunkos in which this rhythmic pattern appears usually in succession. In the next a minor section these external features are also pushed into the background, but even the seemingly typical Hungarian rhythm of the last eightbar unit fails to provide a convincing auditive experience (Example 11). All

\footnotetext{
45 For further details about the story see Bellman: Style Hongrois, p. 73.

46 Zschacke: Weber, p. 211

47 Bellman: Style Hongrois, p. 142.

48 Idem, p. 143.
} 
in all, it can be declared that in the Zigeunermarsch there are merely a few moments that allude to Hungarian verbunkos music, which are not sufficient to let an overall Hungarian character be asserted. Nor was it Weber's aim: all he wished was to strike a slightly flavoured, exotic colour. That is probably why he could associate a musical illustration of utterly different character with the same stratum, the wandering Gypsies, right after that.

The number entitled Chor und Tanz der Zigeuner is "Spanish" in intonation, although Weber does not make it explicit in the title. It contains the same accompanying figures and rhythmic patterns (repeated and figurative triplets of semiquavers) as the instrumental movements entitled Carattere Espagnuolo, Espagnuole, etc. The Spanish character of these movements is just as questionable as was the Hungarian character of the previous march.
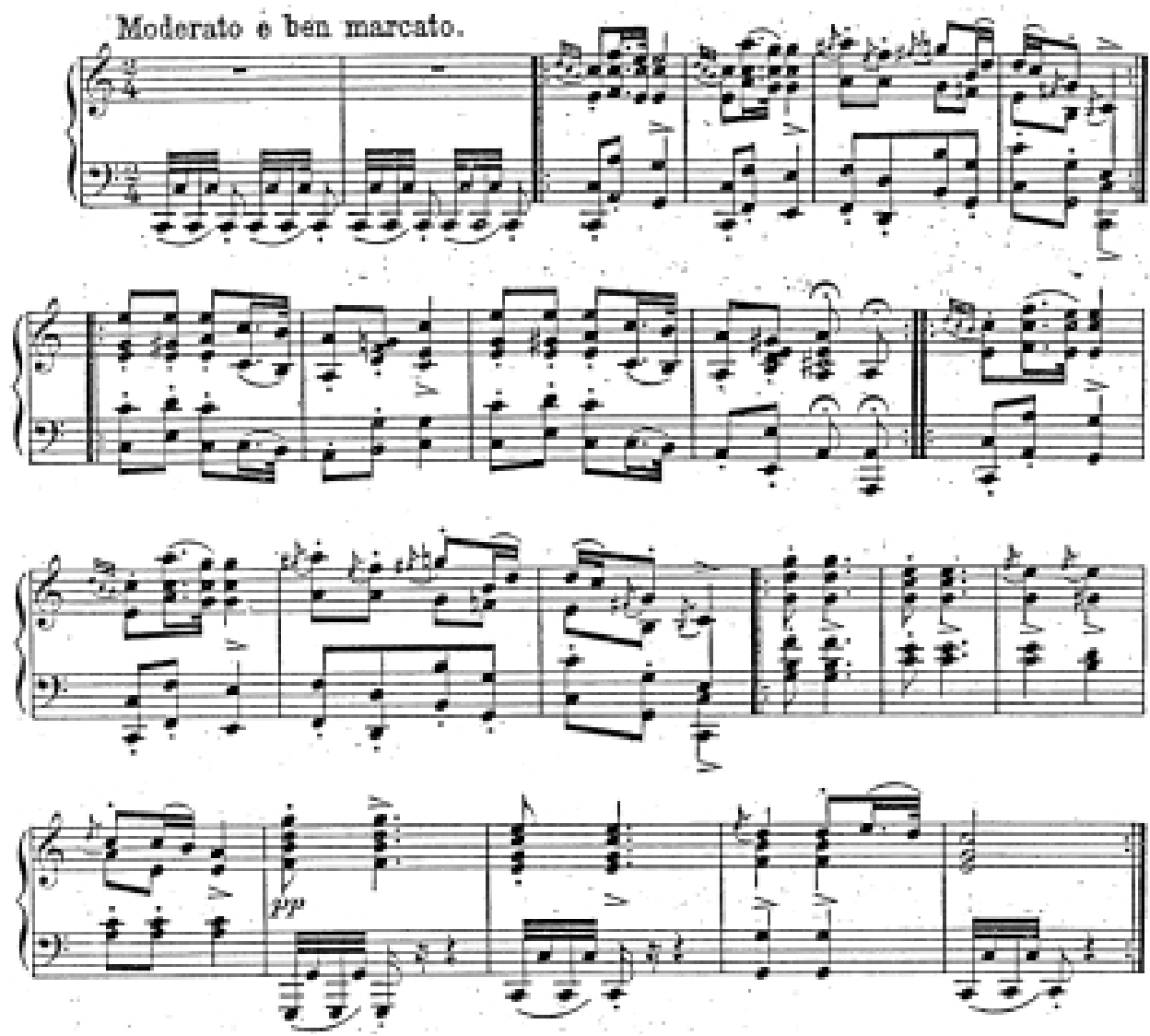

Example 11: Weber: Preciosa, Zigeunermarsch (act 1, no. 1) 
Most instructively, the accompaniment of the Chor und Tanz der Zigeuner in Preciosa is just a hair's bredth away from the typical accompanying pattern of the polonaises which does appear in the fifth bar of the movement, thus it gets enriched with polonaise features at the beginning. Another example of Weber's instrumental music sheds even sharper light on this contradictory situation. In the first movement of the Sonata for violin and piano in $G$ major (op.10, Six sonates progressives,no. 2) the predominant character belongs to the polonaise despite the subtitle Carattere Espagnuolo, whereas the Spanish colour is only represented by a few bars (Example 12).

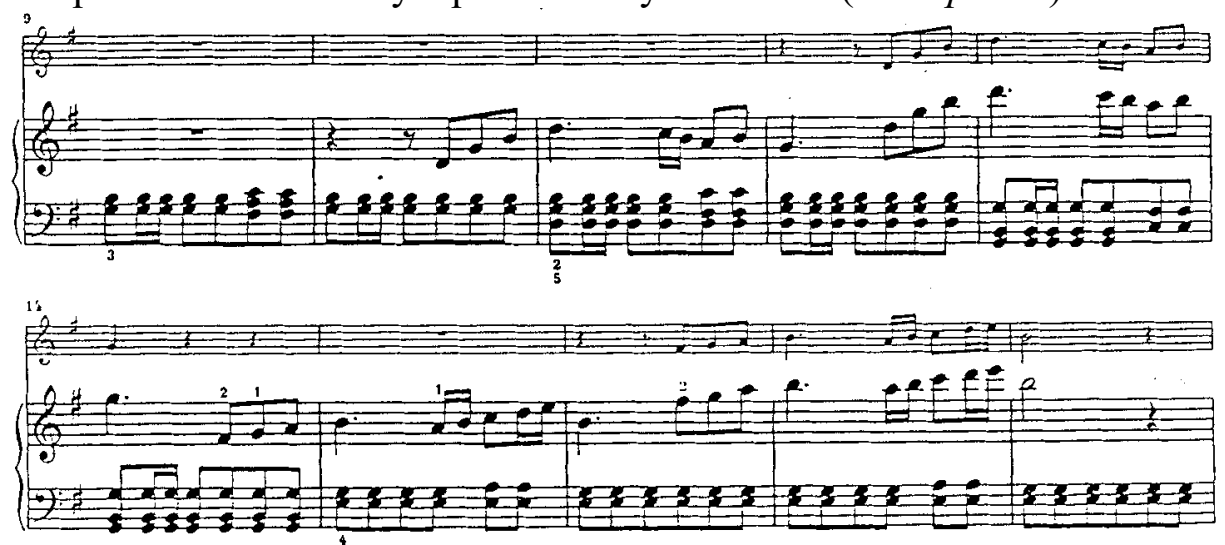

Example 12: Weber: Six sonates progressives (op. 10, no. 2, movement 1, bars 9-18

That this Spanish character is handled very freely by Weber in Preciosa is also shown by the Spanische Nationaltänze in act three, a number of three dances. Under the Spanish label quite new characters appear. Of special interest is the second movement in which one can detect Hungarian elements, although in triple time and in Andante tempo. The sequence shaped from a bokázó formula turns the "Spanish" dance into Hungarian for a short time. Not only the typical motif strengthens this impression but also the chromatic lower auxiliary note it outlines: the raised fourth degree of the minor scale. This semitone step is reinforced by the section of two and a half bars preparing the return of the bokázó theme (Example 13). Despite all these Hungarian elements, the dance movement cannot be declared to be in style hongrois; especially in light of the polonaise rhythm owing to the $3 / 4$ metre. The point is again that Weber used all tools he knew to create an exotic musical background, irrespective of where these tools came from, thus creating a mixed style. 


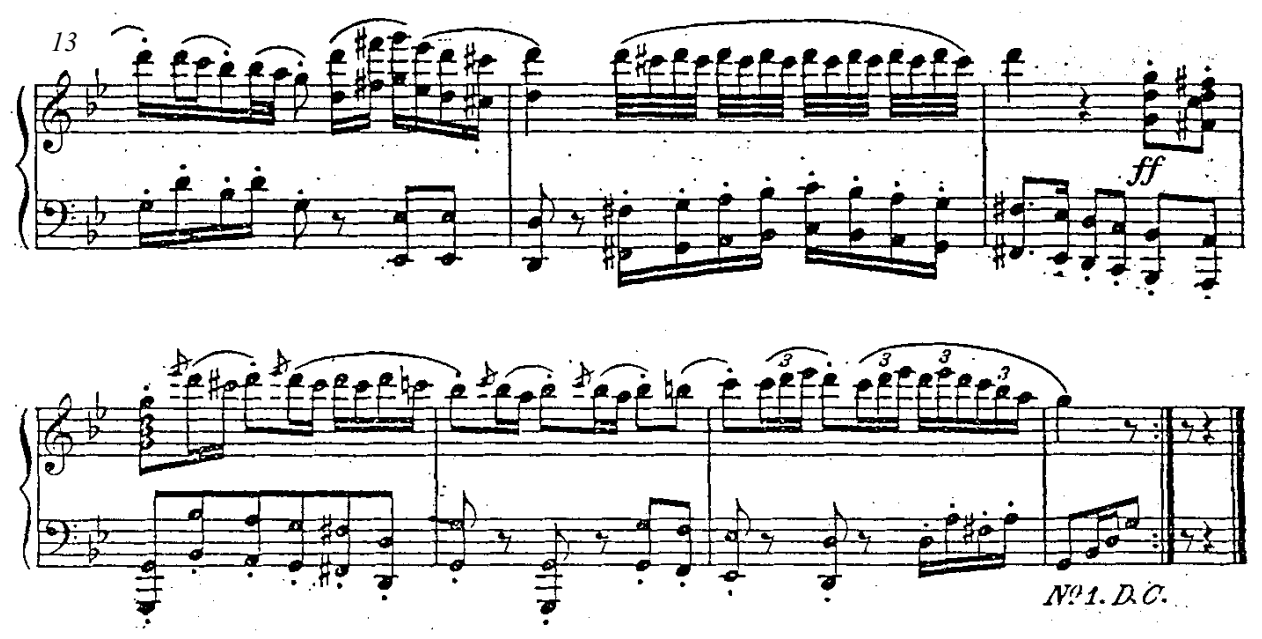

Example 13: Weber: Preciosa, act 3, no. 2 Spanische Nationaltänze, bars 13-19

In Weber's instrumental music this mixed style is represented by the polonaises interlaced with Hungarian elements whose precedents in art music go back to classicism, precisely to one piece by Haydn and one by Beethoven. In the polonaise finales of Haydn's Piano trio in A major (Hob. XV:18) and Beethoven's Triple Concerto in C major (op. 56) one can detect Hungarian elements or episodes as well. This stylistically mixed dance character is perhaps not accidental; among others, Papp also pointed out that in dance transcriptions of the time the polonaise-type Polish dances also contained elements, eg. dotted rhythms, which were typical of the verbunkos. Papp also added that Kodály already noted: the emerging Hungarian verbunkos music must have also incorporated Polish polonaise elements at that time. ${ }^{49}$ As a matter of fact, the appearence of the Hungarian colour in Weber's polonaises can be explained not only by this fact but by his general interest in all sort of exotic features as well. In a group of his polonaises typically Hungarian features are regularly included. In the opening section of his Grand polonaise (op. 21) the same bokázó formula is encountered as is familiar from the Spanish dance of Preciosa. The Hungarian character of the theme is further reinforced by the pendular fourth (kuruc fourth) motif with syncopated accompaniment and by the ensuing turn motif with dotted rhythm, as well as by cadential formulae such as the cadence typically of verbunkos pieces which breaks up the period into little units (bar 2 of the B flat major section follow-

49 Papp: Tánczene, p. 38. 
ing the main theme). The same motif can be found in the seventh variation of Sept variations sur l'air 'Vien qua, Dorina bella' (op. 7) entitled Polacca, as well as the typical bokázó and turn motifs in dotted rhythm.

In the closing section of the Horn Concertino in E minor (op. 45) subtitled Alla Polacca the Hungarian intonation affects a larger musical unit than the usual reference of a few motifs. In the orchestral interlude prior to the last return of the rondo theme the first characteristically Hungarian element is the repeated A minor tutti characterized by alla zoppa rhythm with short ornaments introduced unexpectedly which still elicits an answer from the horn. Further on, the orchestra takes the leading role. The four-bar unit introducing the large $\mathrm{C}$ major tutti is based on the bokázó fomula prepared by Weber with the previous horn solo. Apart from the constant repetition of the bokázó motifs, the composer also presents more original melodic material: though rhythmically remaining in polonaise pattern, the tone colour and melodic outline of the tune moving in paralell thirds lends a genuine Hungarian flavour to the musical material (Example 14).

Hungarianized polonaises, polonaise-like Spanish dances, exotically tinted Gypsy dances, marches, choruses all add up to the conclusion: Weber's exoticisms are not independent of each other but appear cross-referentially, serving to create a variegated but basically homogeneous exotic colour. That is why the elements drawn from a diversity of sources can be alloyed so freely. That fact is analogous with the exoticism of classical music combining Turkish and Hungarian elements. Weber's interest in the exotic, however, is not rooted in classicism only: the appeal of non-German art, as Constantin Floros points out, was a typically romantic trait with analogies in the poetry of early romanticism. ${ }^{50}$ The exotic intonation or "stylized foreignness" created by Weber served to give plasticity to the couleur locale in the stage works, ${ }^{51}$ while in instrumental compositions it allowed for the emergence of sharply pointed character pieces. That was how exoticism and character, two mainstays of Weber's music, were combined.

\section{The Appearance of Style Hongrois} in Weber's Works

Within Weber's exoticism, an exceptional group comprises the works in which the composer tried to evoke a foreign musical style devoid of other ex-

${ }^{50}$ Floros: Weber Schaffen, p. 10.

51 Idem, p. 17. 

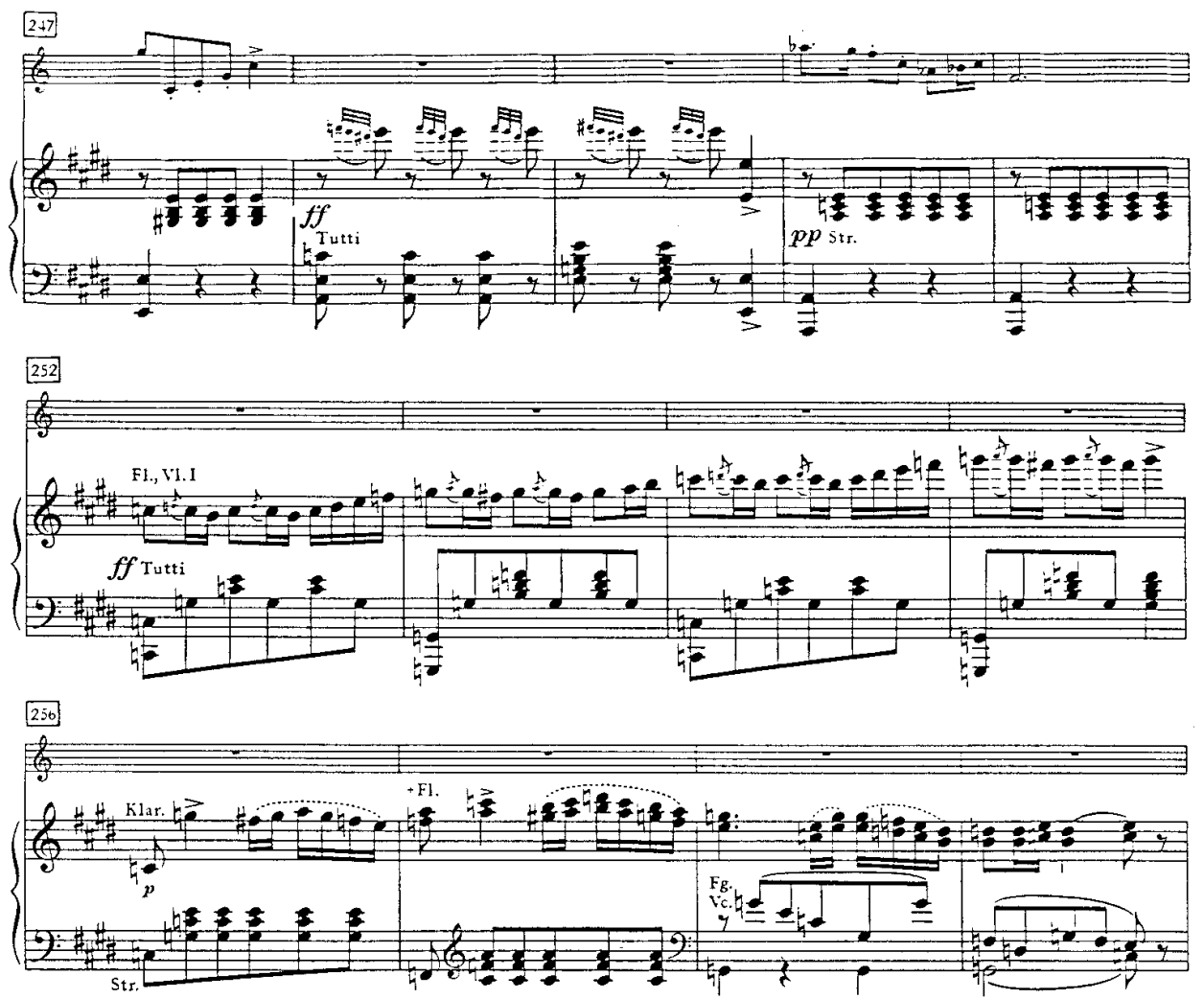

Example 14: Weber: Horn Concertino in E minor (op. 45), Alla Polacca, bars 248-259

otic elements. Such a stylistic attempt is the fast main section of Andante e Rondo ungarese composed for viola and orchestra and rearranged for bassoon and orchestra later (the slow introduction being a siciliano in $6 / 8$ does not belong to our topic) as well as the Alla Zingara 4th movement of Huit pièces for four hands, apparently a less successful outcome of this intention.

Similarly to other Hungarian-related works by Weber, Andante e Rondo ungarese also may have originated from no specific source, as the work was composed in 1809 when he possibly did not have yet the Bihari works sent by Podmaniczky as preparatory study for Preciosa. Posterity is thus reduced to guesswork, presuming that Weber had other sources of verbunkos pieces (which is quite conceivable, in view of the western fashion of the repertory) or he may have heard verbunkos music as performed by some Gypsy band somewhere during his travels. 
The only concrete melody source is related to the rondo theme. In his study Beethoven és Magyarország [Beethoven and Hungary] Major presents a tune with the words Die Hussiten zogen vor Naumburg, which the German song-books define as of Hungarian origin. ${ }^{52}$ The first four bars of the tune are practically identical with the beginning of the Weber theme (Example 15). Apart from that, it is well-grounded to presume that the entire work is based on a thorough knowledge of the verbunkos style since the Hungarian influence is demonstrable with consistency and Haydnian directness almost to the end. It is perhaps not accidental that the choice of the form - rondo - also refers back to Haydn. What also compares the piece with Haydn's ongarese music is its intention to evoke some peculiarities of performance which markedly enhances the Hungarian character in addition to the use of a motivic stock that often relies on typical verbunkos patterns.

What actually makes the rondo theme Hungarian is not merely the fact that it treates a so-called Hungarian melody and it has many verbunkos elements such as the turn motifs in bars 2 and 4 combined with leaping pairs of quavers, but also the accompaniment. This consistent syncopation accentuated on every second quaver gives a distinct rhythmic pulsation to the musical material. The theme's extension into E minor further enhances the Hungarian flavour. Weber enlivens the bokázó pattern and the semiquaver figurations with dotting. The unexpected leaps, changes of register further expand the range of diverse gestures in the theme (Example 15). The complexity of the rondo theme derives chiefly from the differentiation of the musical gestures and the rhythm. That also applies to the second statement of the theme in which the dotted rhythms give way to a new rhythmic pattern, which is no less restrained in its gestures than are the rhythmic formulae of the first statement. The chain of anapaests is animated by ties and unusual accents. At the end of the period the frequent closing formula with a jump to the third refers back motivically to the verbunkos pieces (Example 16).

Rhythmic animation and diversity, various dancing gestures and the occasional referential formulae also characterize the music of the episodes. The $\mathrm{C}$ major section of the first episode is built on two motifs, both typical verbunkos formulae. The first is in dotted rhythm (Example 24), the second in rolling semiquavers. Accents and large leaps play an important role, just as in the A minor section of the same episode, which is in contrast with the previous section both in tonality and via its more static rhythm. The theme of

52 Major: Fejezetek, p. 59. 

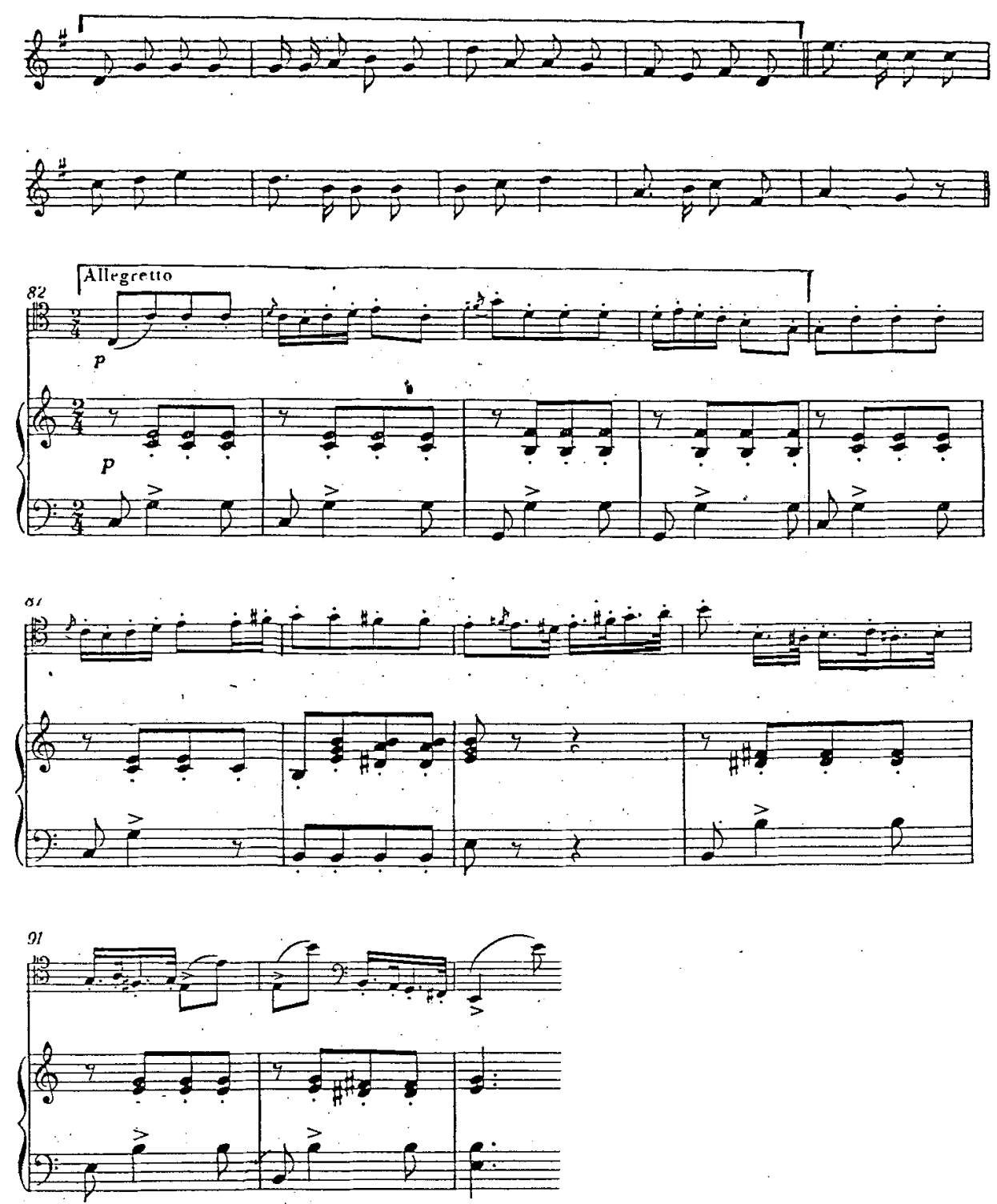

Example 15: Die Hussiten zogen vor Naumburg

Weber: Andante e Rondo ungarese (op. 35), bars 82-93

the third and at the same time last episode begins with a bokázó formula which is almost buried under the dancing motion intensified to galloping by the constant octave changes, giving the simple tune a lot of pep and sweep. The rhythmic liveliness introduced by anapaests throws this character into 


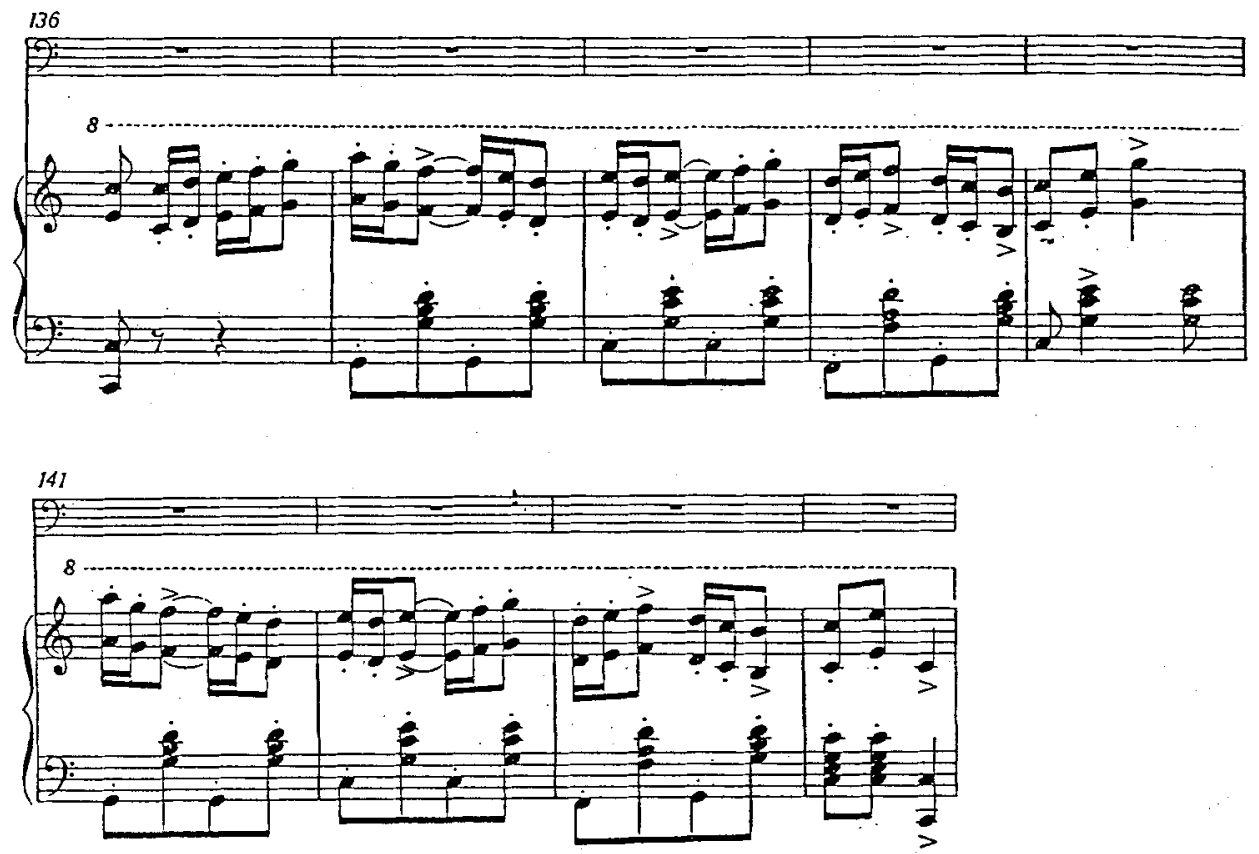

Example 16: Weber: Andante e Rondo ungarese (op. 35), bars 136-144

even deeper relief. The same theme returns at the end of the episode, this time in minor key and in varied form, the large leaps heavily reduced. The minor key and the animated but more compact melodic contour evokes the temperament of some fast verbunkos pieces in minor tonality (Example 17). Rhythmic differentiation, pointed dancing gestures, the motivic material based now on patterns now on free invention, the sweeping melodic writing are all features that characterize the friss dances of mature verbunkos composed to increasingly satisfy the expectations of art music. It is highly likely that Weber already drew on this stylizing stock. It is no accident that in the above-mentioned minor-key theme an intonation can be heard that was to characterize a later phase of the verbunkos.

The consistently Hungarian character only weakens at points where the characteristic features of the mature verbunkos repertory outlined above are overshadowed. Such a place is the cantabile first part of the second episode in which the typical accompanying figure and pregnant rhythm give way to singing musical material. Where the former features assert themselves again, there the typical Hungarian intonation immediately returns. Since the work is not only a Hungarian character piece but also a virtuosic concert 

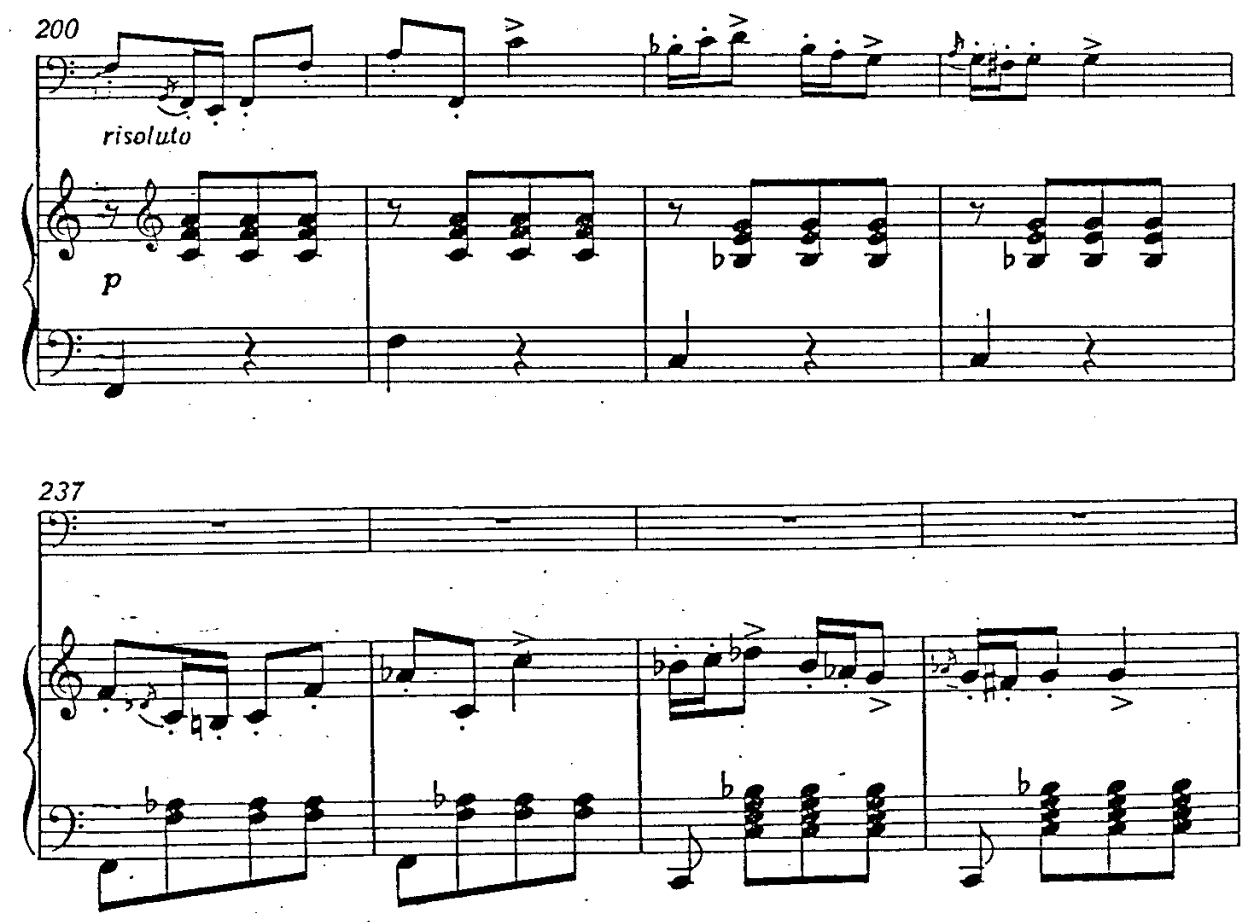

Example 17: Weber: Andante e Rondo ungarese (op. 35), bars 200-203, 237-240

piece, the brilliant style sometimes also dilutes the style hongrois character of the work. It is however also tenable that virtuosity and virtuosic intensification is not alien to the verbunkos but is its immanent part. That is how the coda satisfies the requirements of a virtuosic concert piece and the Hungarian style, all at the same time. The virtuosic runs terminate the work spectacularly, and also, with their motif-repeating structure, refer to the Figura parts of verbunkos pieces (Example 18).

It is quite right to declare in connection with the Andante e Rondo ungarese that Weber's experiment with the Hungarian style was successful. His Hungaricisms are apt, natural and unlaboured, and apart from a few places of less Hungarian contrastive material, it runs throughout the piece. Weber, just like Haydn, did little stylization. The relative degree of stylization in his thematic material derives from the fact that he drew on the style when the verbunkos itself had reached a level of stylization. The elements he borrowed from mature verbunkos are successfully combined with his own personal style and with the requirements of a virtuosic concert piece. 

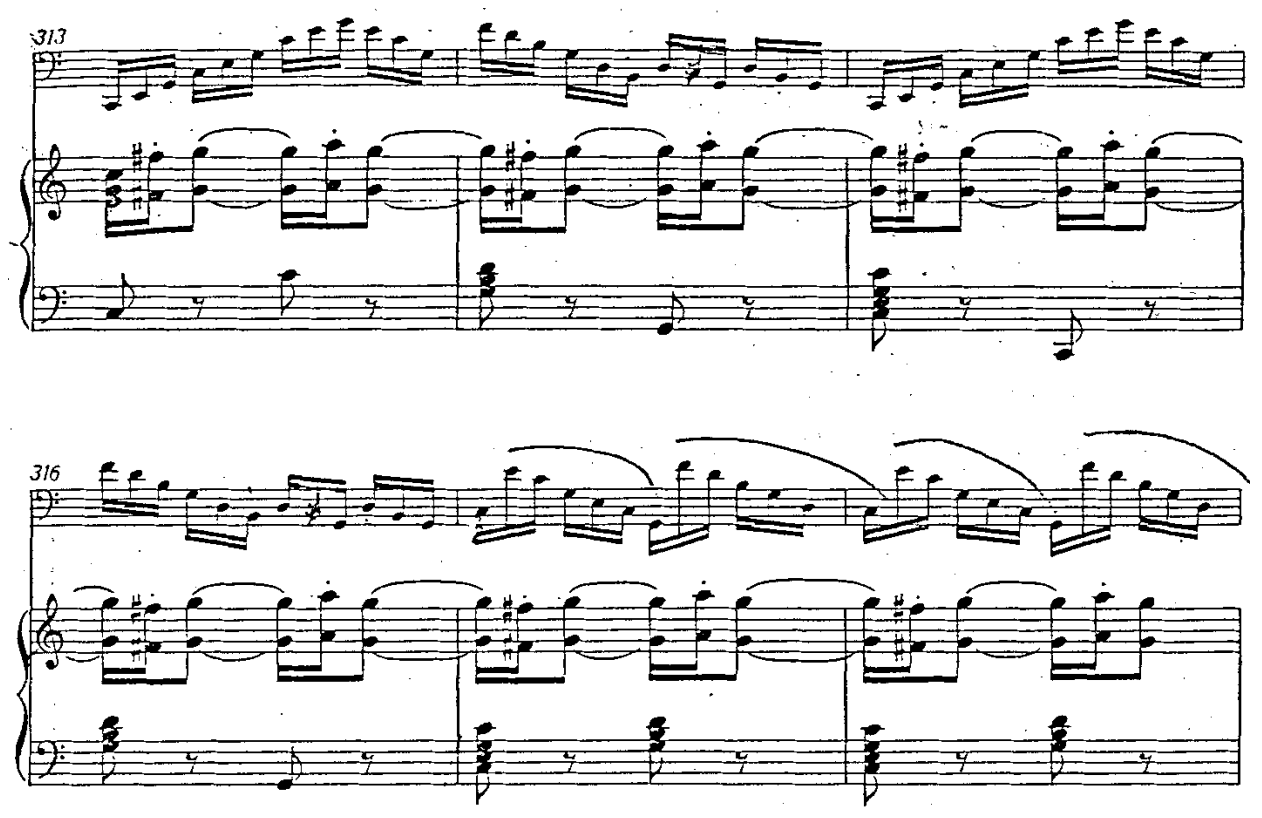

Example 18: Weber: Andante e Rondo ungarese (op. 35), bars 313-316

Weber's other work displaying style hongrois idioms is the Alla Zingara movement in aba form in the series for four hands. It is a less convincing attempt, producing a stylistically more heterogeneous material. Weber used again some patterns, rhythmic elements typical of the verbunkos but their application seems haphazard and superficial at places. Weber put them in the musical texture as external stamps, Hungarian "labels" only without integrating them into the motivic process.

The first part of the movement is built of indepedent musical units of varying length. This structural principle derives from the verbunkos. The only motivic trait the different segments share is the bokázó cadence of every unit. This reference to the verbunkos is not too foreign at the end of the first section of twelve bars; the accompaniment in alla zoppa rhythm and the changed accentuation caused by ties in the theme suggest some Hungarian vigour. This does no longer hold of the second unit (bars 13-30). In vain does the primo include some typical features such as the bar-ending anapaest with the lower auxiliary note in bars 17-18 or the rhythm-animating ties, and in vain is the syncopated accompaniment in the secondo. All these elements fail to add up into a Hungarian melodic outline which is more strongly reminiscent of a light-handed salon style typical of Weber (Example 19). The 

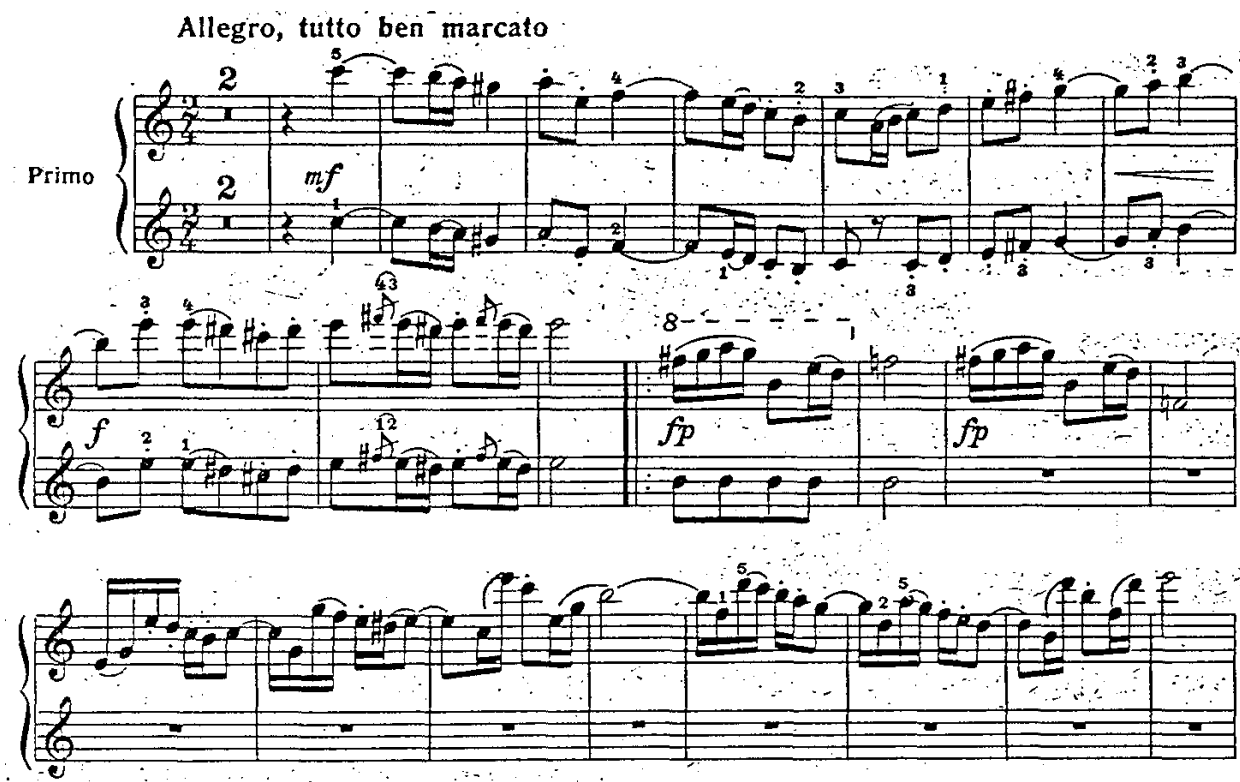

Example 19: Weber: Huit pieces (op. 60 no. 4), Alla Zingara, bars 1-24

composer returns from this style to the level of Alla Zingara with the help of a bokázó cadencial pattern again a few bars later. This, however, sounds very strange in the light of the foregoing musical material and the immediately preceding horn fifths.

The heterogeneity of the work is similarly conspicuous in the fourth unit (bars 55-82). The chromatically tinted turn motifs appearing first in the primo and then in the secondo, then the tied anapaests often appearing as a pregnant Hungarian rhythmic formula in Weber emanate a distinct Hungarian character, whereas the next musical section, though adopting a typical rhythmic pattern of the early verbunkos, can hardly be seen as typical of style hongrois, for the melodic content remains at a level of musical platitudes such as the scale passage outlining the I-VI-IV sequence with hardly any Hungarian allusions. The compulsory bokázó cadence remains just as alien in this musical context as in the previous case and as in the A major, nonHungarian, middle section where it only remains a perfunctory allusion.

Besides the little or partly convincing Hungaricisms, however, there are peculiarities in the work whose analogies can be found in the verbunkos repertory. One of these - the one concerning overall construction of loosely related self-contained units - has been mentioned. The other also affects the 
structure of the movement: it is often observable that Weber arranged the musical units asymmetrically. This produces at times irregular bar grouping that are frequent in mature verbunkos. The third musical section of the first part begins with two regular two-bar motifs, followed by the third two-bar unit but the stepping crotchets of bar 6 that launch a new motivic pattern reshuffle the so-far regular metric pattern and the twelve bars get divided into $5+4+3$. The shift of accent between the bars produces an asymmetry that can be detected at the end of the fourth musical unit as well. Asymmetrical construction is even more explicit in the coda: the bar number is odd (nine bars), hence its subunits can only be odd, containing 3 bars each (Example 20).

The weaker Hungarian flavour of the thematic material is suprising as Weber had already written a more characteristic work in style hongrois, Rondo ungarese, which means he had a command of the style. At the same time, the structural and formal features suggest that the composer deliberately applied these peculiarities, that is, drew on the verbunkos as his source. That Weber applied the asymmetrical patterns to enhance the Hungarian character of the work is also confirmed by the fact that asymmetrical construction is not typical of his other works, thus this extraordinary solution was meant to illustrate some unusual or exotic, this time Hungarian, character. On the other hand, however, there is another - similarly exceptional - work in Weber's oeuvre on account of its asymmetric construction: the first movement of the Sonata for violin and piano in D minor (op.10, Six sonates progressives, no. 3) whose main theme consists of two three-bar and a five-bar units (Example 21). The movement is subtitled Air russe, which raises the question whether the asymmetrical construction was exclusively a typical Hungarian specificity for Weber or not. The knowledge of the latter works raises doubts about it, but it does not preclude the possibility that the composer might have learnt the use of asymmetrical patterns from the verbunkos.

At any rate, all these elements contributed to Alla Zingara giving some Hungarian impression despite the sylistically mixed material adorned superficially with Hungarian elements. Yet the movement lags behind the subtlety and inventiveness of the stylistic play characterizing Rondo ungarese, directly continuing the path staked out by Haydn.

These two are actually the only works in which the Hungarian influence can be demonstrated and which allude to it in their titles directly or indirectly. Though seemingly Sieben Variationen über ein Zigeunerlied belongs here, a closer look will reveal that the Hungarian intonation - if any at all - is 

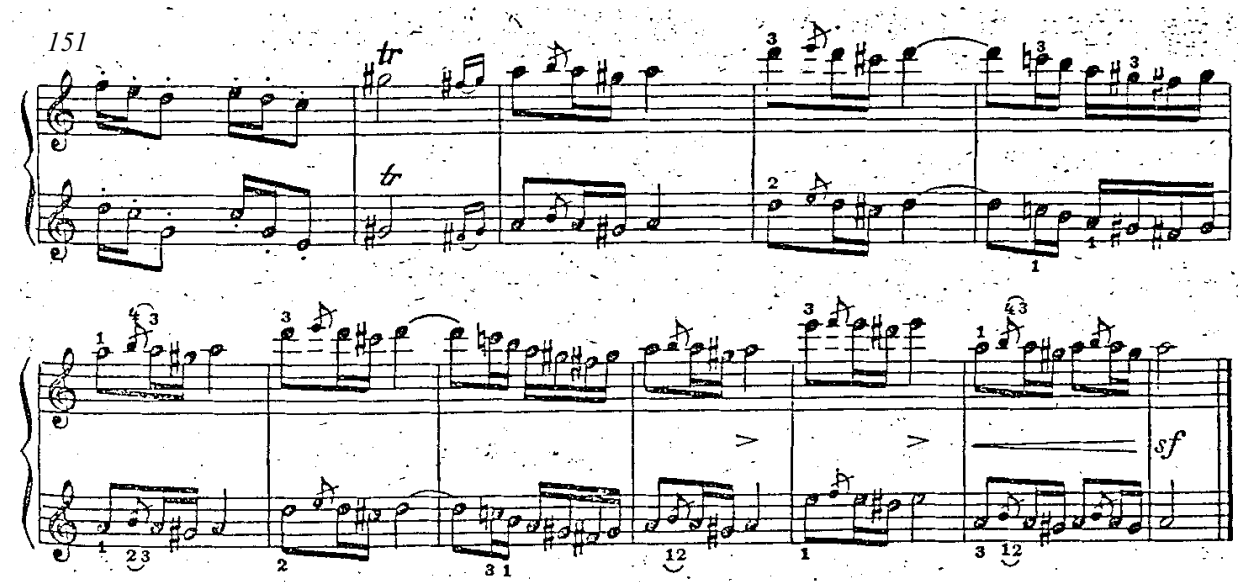

Example 20a: Weber: Huit pieces (op. 60 no. 4), Alla Zingara, bars 154-162

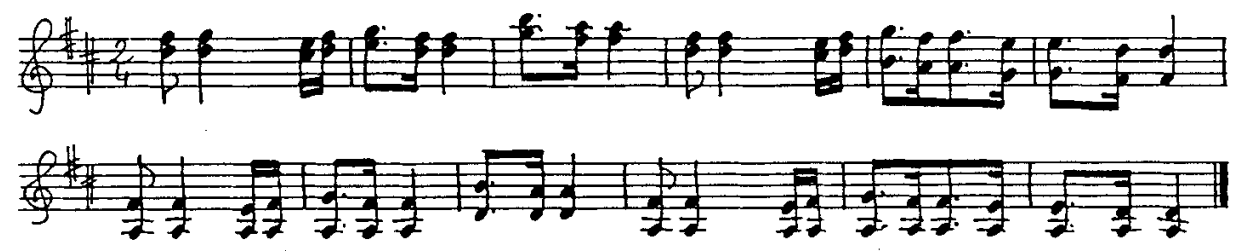

Example 20b: Csermák: Ugrós [Jumping Dance], 3rd Finale
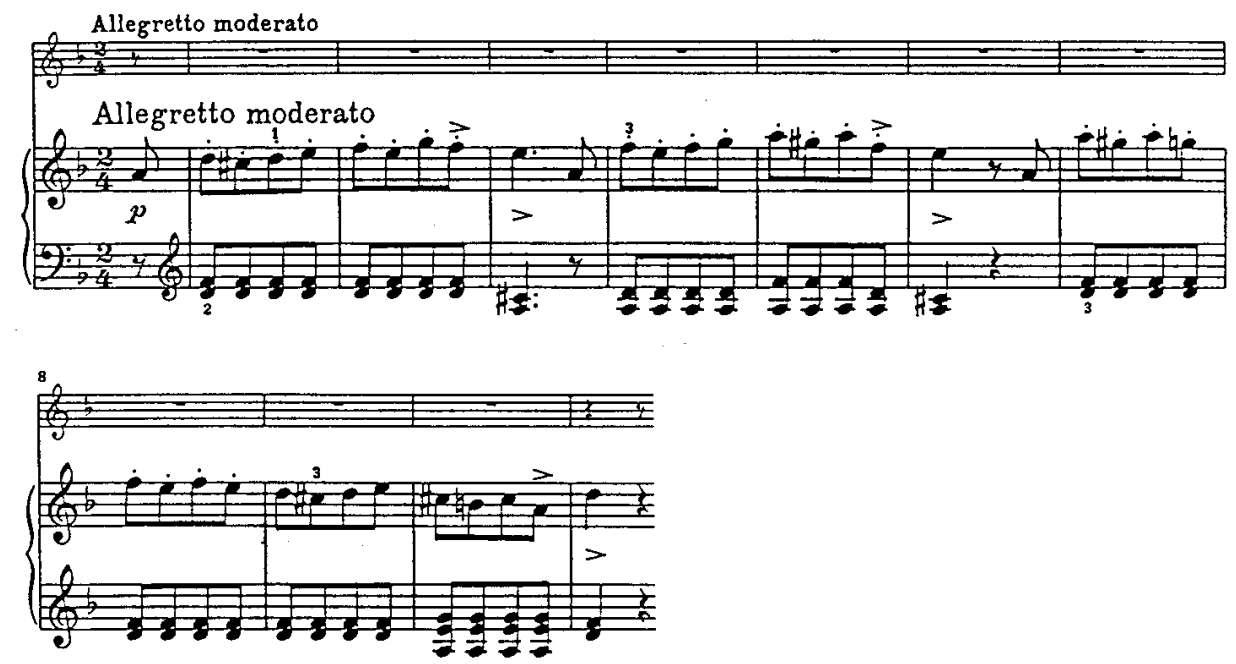

Example 21: Weber: Six sonates progressives (op. 10 no. 3 ) movement 1, bars 1-11 
only the starting point, an excuse for Weber to unfold a series of virtuosic variations adjusted to classical models. As regard Hungarian character, no variation goes beyond the - rather narrow - frames set by the theme. There is no clue in the Weber literature as to the origin of this theme. The title suggests a vocal source, whereas the scoring is inherently instrumental. The closure of the second part of the theme is a typical verbunkos fumula, while the starting motif resembles the launch of the E minor section of the HungarianTurkish episode also using verbunkos elements in the third movement of Mozart's Violin Concerto in A major. The first part, however, displays little verbunkos influence (Example 22). It can be imagined that underlying the theme was an originally vocal (probably not Hungarian) tune that survived in the instrumental performance of Gypsy musicians, hence enriched with certain Hungarian elements. In the course of variation these elements were then relegated somewhat into the background, therefore the work has no more conclusions for style hongrois.

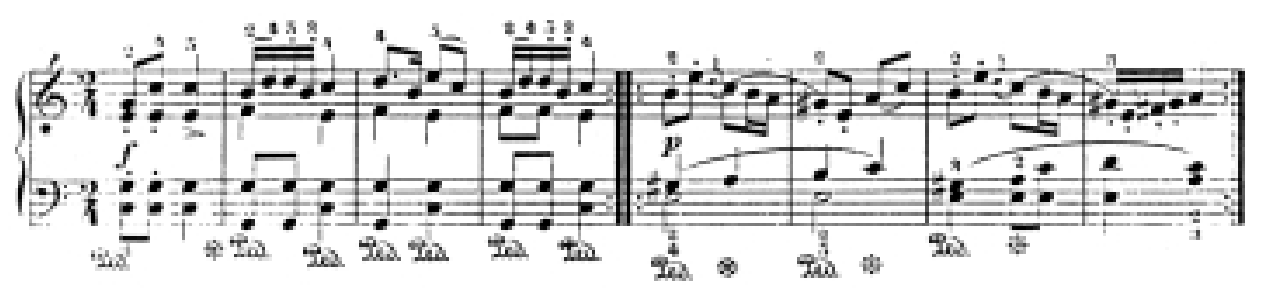

Example 22: Weber: Sieben Variationen über ein Zigeunerlied (op. 55), theme, bars 1-8

\section{Hidden Hungarian References in Weber's Music}

No investigation of the Hungarian influence in Weber's work can shun the question whether there are works in his oeuvre that include Hungarian elements or episodes without the composer making explicit reference to them. This is all the more important as the composers who were intrigued by Hungaricisms usually applied features of the Hungarian style without noting it in the title of the movement or work.

For want of a complete Weber edition, there can be no exhaustive analysis of this kind, yet there are at least three works that need to be considered in this context. The Grand pot-pourri for cello and orchestra (op. 20, 1808) may be interesting for its contacts with Rondo ungarese. It is a similarly virtuosic concert piece, but it has three continuous movements, instead of 
two. The Hungarian influence is discernible in the third movement, in this case too, in rondo-form. The theme itself is related to the dance-like beginning of Rondo ungarese (Example 23), but that is not the main reason why it is counted among the works with Hungarian relevance, since the theme in Grand pot-pourri lacks the Hungarian gestures of Rondo ungarese. In its second episode, however, (bars 310-354) some typical Hungarian motifs do crop up which are to return in Rondo ungarese. They include the first four bars of the cello solo following the orchestral exposition; it is a repeated twobar motif, the first bar predominated by turn figures in dotted rhythm, the second by leaping quavers. The motivic relation between this unit and bars 3-4 of the first episode of Rondo ungarese is obvious (Example 24). The cello solo of the pot-pourri remains predominated by the dotted rhythm reinforcing the Hungarian character, though the long scale passage is not expressly a Hungarian element. It is, however, noteworthy that the structure of the scale passage part is identical with bars 136-144 of Rondo ungarese, the termination of the second appearance of the rondo theme, that is. In both cases we have a period in which the two half periods are determined by the

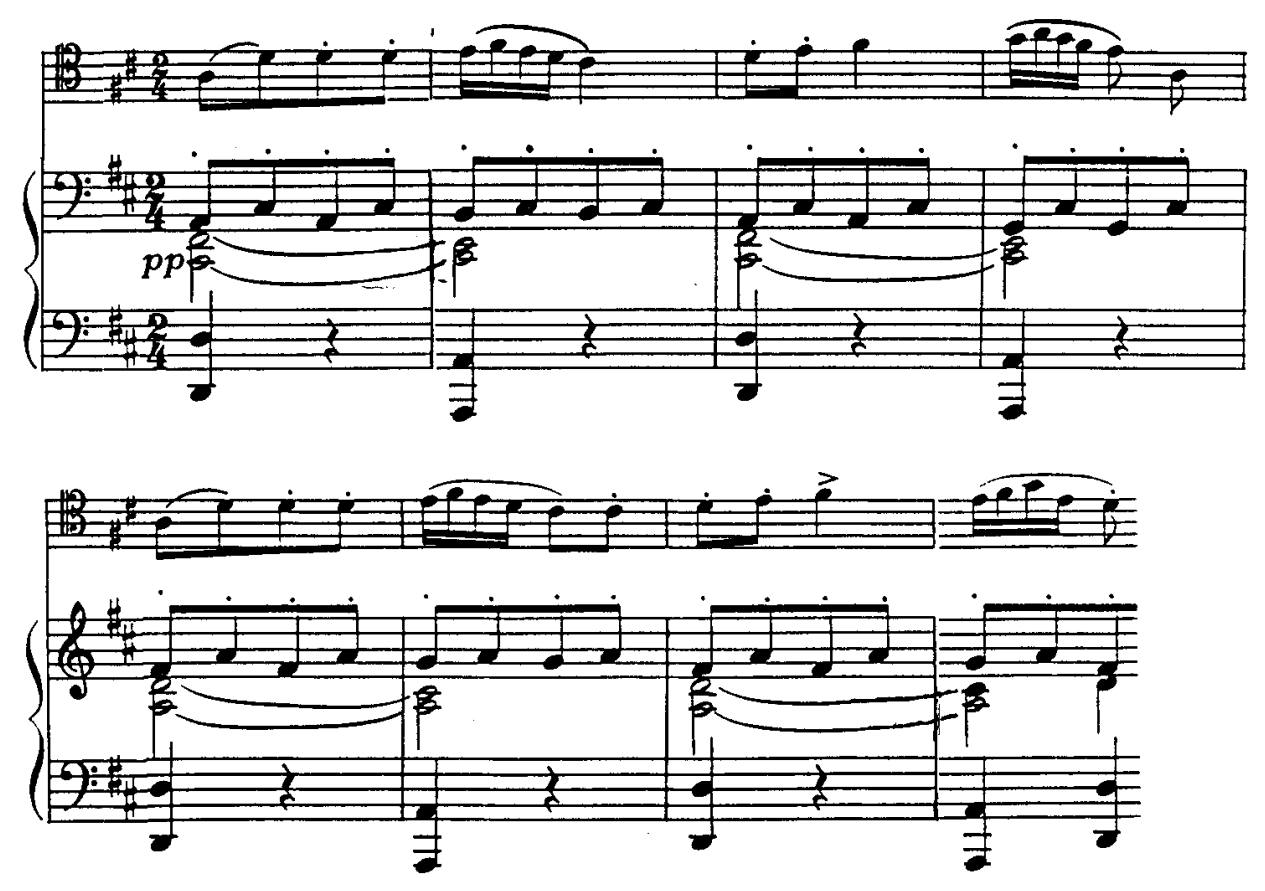

Example 23: Weber: Grand pot-pourri (op. 20), bars 242-249 (see also Ex. 15) 

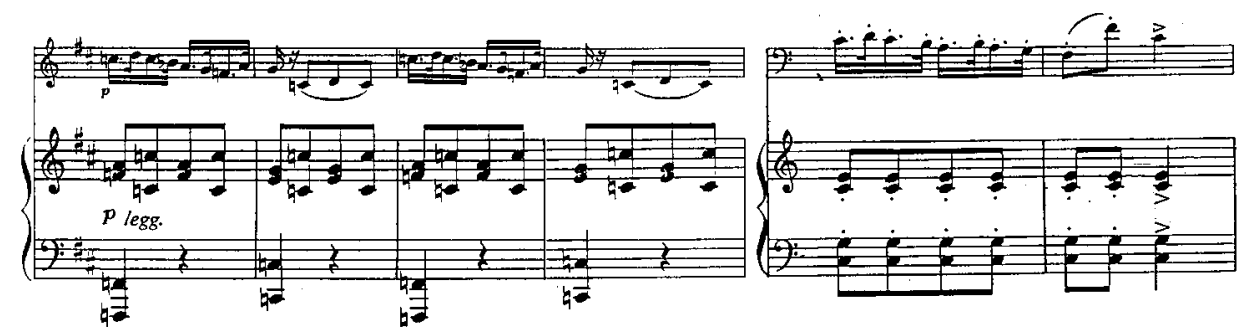

Example 24: Weber: Grand pot-pourri (op. 20), bars 314-317

Weber: Andante e Rondo ungarese (op. 35), bars 107-108

same rhythmic sequence. In the fourth and eighth bars of the period, similar motifs articulate the motion (Example 25). The last notable instance is the two-bar motif introduced after the scales, which is none other than a variant of the rondo theme predominated by dancing gestures - a close variant of the theme of Rondo ungarese. Weber seems then to have taken a liking to the Hungarian character already when he was composing the Grand pot-pourri and he tried out some idioms in the Hungarian episode. The main stress, however, is not yet on this character; it serves as a preliminary study, so to say, to the mature style hongrois work, Rondo ungarese.
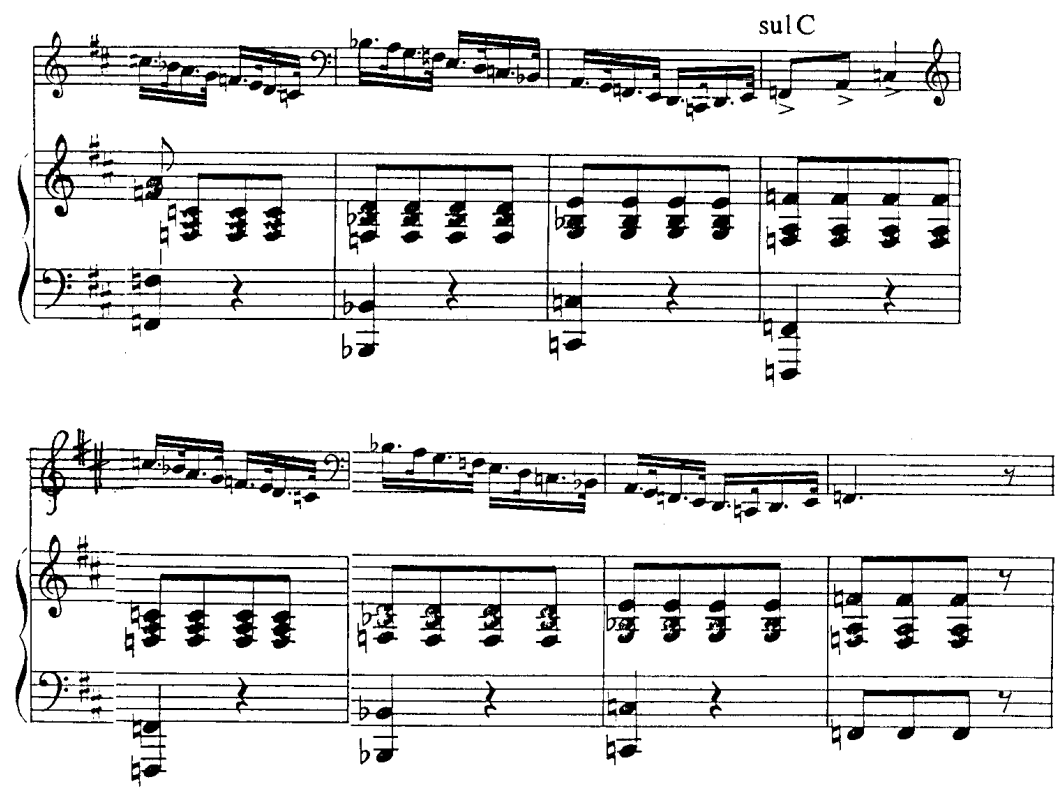

Example 25: Weber: Grand pot-pourri (op. 20), bars 318-325 (see also Ex. 16) 
The rest of the examples displaying Hungarian influence are from the composer's piano output. Typically Hungarian intonation appears in a variation of Air russe (Schöne Minka) 9 variations (op. 40) and Variations sur un theme originale (op. 9). The seventh variation of Schöne Minka is a C minor movement in Poco adagio tempo, conspicuously predominated by dotted semiquavers. Its rhythm, tempo and pathetic character all suggest that it was patterned after the "tight, giusto" type of the slow dances of mature verbunkos, in which the sombre intonation typical of "stately" verbunkos appears (Example 26). Apart from the dotted rhythm, the melodic shape of the theme-head is also strongly reminiscent of Hungarian music: the upward thrusting minor scale with augmented second elicits Hungarian allusions, together with the pendular fourth in the inner part of bar 2, as well as the motif in bar 2 consisting of progressiv anticipations in dotted rhythm. In bars 34 of the theme motivic allusions to the verbunkos gradually dwindle and since harmonization is determined by the theme in the bass, the Hungarian influence is no longer unambiguous. The theme-head, however, returns three times, the formal scheme being: $\mathrm{a}_{1}(4 b s)+\mathrm{a}_{2}(4 b s): \| l: b(4 b s)+a_{2}(4 b s): l$, therefore it is the main determinant of the character of the movement influenced partly, though not exclusively, by one of the most typical intonation types of mature verbunkos.

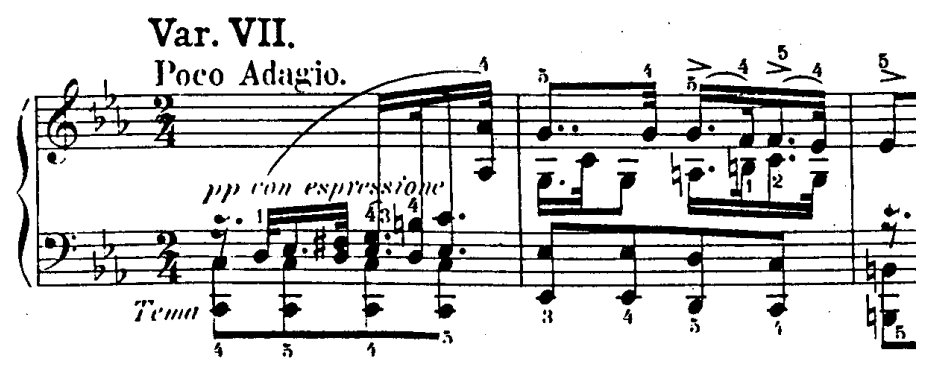

Example 26: Weber: Air russe (Schöne Minka) 9 variations (op. 40), var. 7, bars 1-2

A typical intonation can be found in the 6th variation of the op. 9 series. It is a slow movement whose arioso section is framed by a section subtitled Fantasia. Largo. - Recit. Its musical material reminds one strongly of another type of mature verbunkos, the freer, quasi rubato slow Hungarian dances. Weber applied the free runs, rhapsodic switches typical of these pieces in the Recitativo. Noteworthy is the chromatically embellished dotted $\mathrm{C}-\mathrm{G}$ pendular fourth (kuruc fourth) following the starting runs of the 
Recitativo as well as the bokázó pattern closing off the next motif of dotted rhythms. Here, the bokázó is not of a dancing character but adjusts to the freer tempo. The sweeping coloraturas articulated with holds and long rests, the passionate outbursts all contribute to the suggestive presentation of the intonation (Example 27).

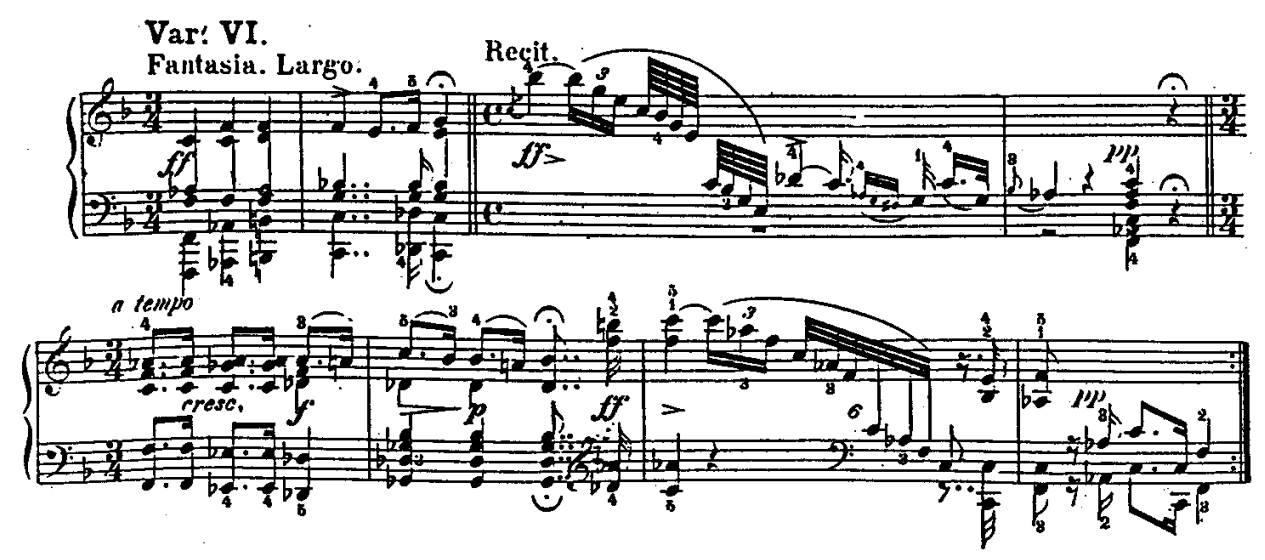

Example 27: Weber: Variations sur un thčme original(op. 9), var. 6, bars 1-8

Especially the latter two Weber movements can be seen as passages towards the romantic reinterpretation of style hongrois. While Rondo ungarese (with Grand pot-pourri behind it) proposes the summary of the most characteristic features of the style - along the path designated by Haydn for style hongrois, the two "Hungarian variations" anticipate the possibility of expressing inner contents, even if in rudimentary form, that start out from the most typical intonation of verbunkos but step beyond it to create a new programmatic aspect of style hongrois, $\mathrm{w}$

hich was to enrich the expressive spectrum of romanticism.

4. Franz Schubert and Style Hongrois.

Schubert's Contacts with Hungary and Hungarian Music

Unlike Weber, Schubert had direct contacts with Hungary; not only because as a composer in Vienna, he was literally "closer" but because he had a number of Hungarian acquaintances and had first-hand experiences of the country. He had two long stays in Hungary. First lasted from July to November 1818 , the second took place between May and October 1824. On both occasions he was employed by Count Johann Karl Esterházy as the music teacher 
of the family, or to be more precise the two girls, Marie and Caroline. The venue of the piano lessons was Zseliz (today Zeliezovce) in the area of today's Slovakia. ${ }^{53}$

However, Schubert saw more places than Zseliz alone. During his first sojourn especially, he made several excursions and visits to other nearby places. His favourite destination was Tergenye (today Trhyna) $1 \mathrm{~km}$ away from Zseliz where he was in touch with a miller and his family of German origin, who spoke good German and Schubert liked to while away the time with them. ${ }^{54}$ His planned trips described in a letter dated August 25, 1818, are however more relevant to our subject. The letter does not reveal whether the trips were realized or not, nor has Zuzana Vitálova, a researcher of the documents of Schubert's stay at Zseliz found any further information, so she can but presume that they were realized. ${ }^{55}$

The relevant passage of the letter reads as follows:

Ich hoffe künftigen Monath auf einige Wochen nach Freystadt [Galgóc] zu kommen, welches dem Grafen Erdődy, dem Onkel meines Grafen, gehört. Die Gegend soll dort ausserordentlich hübsch seyn. Auch hoffe ich nach Pest zu kommen, indem wir in Bosczmedjer [Pócsmegyer] Weinlese halten, welches nicht weit davon entfernt ist. ${ }^{56}$

Documenting the latter journey would be highly illuminating, not only because a possible trip to Pest could also have been included, but also because the mentioned wine-harvest celebrations could involve spontaneous music-making which would allow the composer to gain first-hand experiences of the performing style and repertory of Gypsy musicians.

Although there is no letter or note by Schubert that refers to such experiences, his friends' recollections allow us to assume that the musical influences he received in Hungary were important for him. Anselm Hüttenbrenner wrote to Ferdinand Luib, one of Schubert's biographers that Schubert was deeply interested in Gypsy music (verbunkos music played by Gypsies) and he collected material for his Divertissement à l'hongroise during his stay in Hungary. ${ }^{57}$

It is highly likely that Schubert had the opportunity to get acquainted with efflorescent verbunkos in authentic interpretations apart from the folk musics of the people around him when he stayed at Zseliz, Tergenye or per-

\footnotetext{
53 Data in Vitalová: Zseliz, p. 94.

54 Idem, p. 98.

55 Vitalová: Umkreis, p. 39.

56 Schubert Dokumente, p. 64.

57 Bellman: Style Hongrois, pp. 159-160.
} 
haps Galgóc and Pócsmegyer, or again, when he visited the Szerdahelyi family in 1818 or 1824 at Csúz ${ }^{58}$ (today Dubník). It must have been the impression of live performance that he could get during these visits which was the surplus over the already known verbunkos music from various sources. In 1814 he transcribed Wenzel Matiegka's guitar quartet op. 21, the fourth movement of which is Zingara based on a verbunkos tune. ${ }^{59}$ Although there is no other factual information at our disposal, it is most probable that the rich supply of verbunkos music on the Viennese music market was not unknown to Schubert. Thus, he had some knowledge of the verbunkos, which he further enlarged and deepened during his sojourns in Hungary - as suggested by his friends' recollections and the documents of his life about these stayes.

In addition to the musical impression, the personal impacts Schubert sustained in Hungary cannot be ignored, either. Any analysis of the topic would rely on Schubert's few letters written about his life in Hungary for those at home. At the beginning of his first stay in Zseliz, the letters suggest the composer was optimistic and good-humoured.

Ich befinde mich recht wohl. Ich lebe und componire wie ein Gott, als wenn es so seyn müssen, ${ }^{60}$

he wrote in a letter of August 3, 1818. Work left him enough time to indulge in the simple rural way of life so different from life in Vienna. A letter of September 8,1818 reveals that he took part in a cow and ox auction. ${ }^{61}$ In his mentioned letter of August 24, he enthused not only about the prospective vintage but also about the harvest:

Auch die Ernte ist hier sehr schön. Man brings hier das Getreide nicht wie in Österreich in Scheuern, sondern man errichtet auf freyen Felde ungeheure Haufen, welche man Tristen nennt. Sie sind öfters 40 bis 50 Klafter lang und 15 bis 20 hoch. Sie wissen es so geschickt zu legen, dass der Regen, welcher ablaufen muss, keinen Schaden machen kann. Hafer und dergleichen vergrabt man auch in die Erde. ${ }^{62}$

But the idyllic visions of neither the cow market, nor the harvest or the expected vintage could overshadow the world that was truly Schubert's. The letter goes on after the harvest:

\footnotetext{
58 Kiemle: Schubert in Czúz, p. 131.

59 Domokos: Schubert gitárkvartett, p. 57.

60 Schubert Dokumente, p. 62.

61 Idem, p. 66.

62 Idem, p. 64.
} 
So wohl es mir geht, so gesund als ich bin, so gute Menschen als es hier gibt, so freue mich doch unendlich wieder auf den Augenblick, wo es heissen wird: Nach Wien, nach Wien! Ja, geliebtes Wien, Du schliessest das Theuerste, das Liebste, in Deinen engen Raum, und nur Wiedersehern, himmlisches Widersehen wird diese Sehnen stillen. ${ }^{63}$

With the passing of the time, Schubert's homesickness grew immensely, together with the disappointment caused by his immediate environment.

During his second stay in Zseliz Schubert tolerated even less his "exile" in Hungary. The composer's letters from this period outline the portrait of a lonely and destitute person disillusioned for a variety of reasons, not only for his visit to Hungary. In a letter of September 21, 1824, he wrote to Schober:

Waren wir nur beysammen, Du, Swind, Kuppel u. ich, es sollte mir jedes Mißgeschick nur leichte Waare seyn, so aber sind wir getrennt, jeder in einem andern Winkel, und das ist eigentlich mein Unglück. [...] Nun sitz ich allein hier im tiefen Ungarlande in das ich mich leider zum 2ten Mahle locken ließ, ohne auch nur einen Menschen zu haben, mit dem ich ein gescheidtes Wort reden könnte. [...] Ungeachtet ich nun seit 5 Monaten gesund bin, so ist meine Heiterkeit doch oft getrübt durch Deine und Kuppels Abwesenheit, und verlebe manchmal sehr elende Tage. ${ }^{64}$

Though Schubert's depression was caused by a multiple of reasons - the scatter of his friends, professional failure and the rejection of publishers as another letter reveals - his state must have been badly intensified in the bleak Hungarian "wasteland" without real companions in spirit. His attraction to Caroline Esterházy, an emotion at times over-romanticized, at times underestimated in the Schubert literature, cannot have altered his solitude but further enhanced his desolation.

All in all, the emotional effects Schubert experienced in Hungary were negative rather than positive. The overall impression about his stay must have predominantly in a "minor key", to use a musical simile. To what extent these impacts affecting the private person rather than the composer Schubert affected the musical shapes of the Hungarian influence in his oeuvre cannot be known for sure. But the appropriate liveliness, emotional depths of his style hongrois could possibly not be imagined without Schubert's stays in Hungary that were mostly hard times for him.

\footnotetext{
${ }^{63}$ Idem.

${ }^{64}$ Idem, p. 258.
} 


\section{The Evaluation of the Hungarian Influence in the Schubert Literature}

As regards the evaluation of style hongrois in the Schubert literature, one finds contradictory opinions. The most frequently investigated questions include what the Hungarian style meant for him, if it meant anything at all, and if it did, in which works and in what ways it appeared. The conflicting answers and the superficial remarks passed on different works enhance the confusion. No comprehensive view can be developed from them.

The most extreme position is Maurice J. E. Brown's who claims flatly that the different folksong influences and the alleged Hungarian influence in some works can be disregarded lock, stock and barrel. ${ }^{65}$ He practically denies that apart from Divertissement à l'hongroise (D 818), the only work in which the composer deliberately used Hungarian themes and indicated it in the title, there is any covert Hungarian influence in his works not expressed in the title or movement subtitle. ${ }^{66}$ He then lists works which, in his opinion, are erroneously listed as thematically Hungarian. This list includes, for example, the Fantasy in C major for violin and piano (D 934) with clearly several Hungarian features, and also the Fantasie in f minor (D 940), which is understood by some scholars (e.g. Alfred Einstein ${ }^{67}$ and Jonathan Bell$\operatorname{man}^{68}$ ) to contain Hungarian elements, but which can hardly be ranged with the Hungarian-related work in view of Schubert's other style hongrois compositions and in the most case underlying verbunkos material.

Similarly questionable statements can also be found in Einstein's book. He attributes the Hungarian epithet to several works whose Hungarian character is at least doubtful. And conversely, he fails to list such important works for style hongrois as the mentioned Fantasy in C major and the $\mathrm{C} \mathrm{ma-}$ jor string quintet (D 956). Although Einstein discusses these works in detail, he fails to note their Hungarian relations. ${ }^{69}$

While the above books only touch on this theme in tangentially, Bellman's book on 19th century style hongrois is aimed to provide an all-round picture. ${ }^{70}$ His analyses, more detailed than the ones mentioned above are not always musically convincing, nor do they concern all works listed by Bell-

\footnotetext{
65 Brown: Schubert, p. 216.

66 Idem, p. 217.

67 Einstein: Schubert, p. 320.

68 Bellman: Style Hongrois, pp. 169-170.

69 Einstein: Schubert, pp. 315, 333-334.

70 Bellman: Style Hongrois.
} 
man among the compositions displaying Hungarian influence. The list of these works are appended to the end of Bellman's book..$^{71}$ There are some arbitrary items in the list: it includes some pieces or movements which are not discussed by Bellman and would indeed be hard to analyse them as having style hongrois features, e.g. Impromptu in fminor (D 935, no. 4).

All this will have made it clear that the problem is more complicated than it appears at first sight. One reason must be that however objective an analyst attempts to remain, he/she cannot help letting some subjective factors sneak into an investigation of influences of this kind. A variety of opinions concerning Schubert's Hungarian-related or allegedly Hungarianrelated works add up, which may partly facilitate and partly compound the examination of the theme. Unlike with Weber, the investigation of style hongrois in whose work had to start from scratch and that caused the uncertainty, in the case of Schuber the difficulty lies in the frequent but rarely profound discussion of the theme. Though one cannot naturally ignore the relevant research literature, the best method is probably to start out from the works themselves and to try to understand the relation between Schubert and Hungarian music from striking style hongrois examples.

The Divertissement à l'hongroise and its Precedent, the Ungarische Melodie

The date of Divertissement à l'hongroise's composition is uncertain. The list of works in Grove's Dictionary sets it at autumn 1824 upon the researches of Deutsch, while Mária Domokos dates it about a year later, to the autumn of $1825 .^{72}$ It is certain that the piece is related to Schubert's stays in Hungary, even if he did not compose it during his second visit to Zseliz but somewhat later.

At first, it is the genre that ranges it with other works composed in Hungary. Schubert's repertory for four hands substantially increased during both his stays at Zseliz. What directly inspired Schubert to compose these pieces was the conviction that teaching the two young countesses the piano and music in general was most suitably done via such works for four hands. Although Divertissement is not dedicated to them but to one of Schubert's friends in Vienna, the wife of the Hungarian Miklós Lacsny, Katharina, ${ }^{73}$ it

\footnotetext{
71 Idem, p. 225-226.

72 Domokos: Divertissement, p. 7.

73 Idem, p. 6.
} 
cannot be disregarded that Schubert's interest in music for four hands did increase in Zseliz. The Hungarian thematic materials of the work tie it even more tightly to Zseliz. Besides several verbunkos elements, the work also relies on folk music sources. The recollections of Baron Karl von Schönstein also confirm this, who noted in 1857 that Schubert treated a melody sung by a kitchen-maid for Divertisssement. ${ }^{74}$ The short piece, Ungarische Melodie (D 817) $)^{75}$ for two hands also ties the work to Schubert's second stay at Zseliz where it was undoubtedly composed, on September 2, 1824. It was the point of departure for the third movement of Divertissement à l'hongroise: its first thematic material was converted by Schubert into the rondo theme, the last section became the coda.

Divertissement claims signal attention for its connections with Hungarian music. In this work, style hongrois appears so intricately, with such wealth of musical and emotional contents that was unprecedented in the history of style hongrois so far.

a) The structure of the work

Schubert's Divertissement à l'hongroise has three movements; the middle one is a relatively short and simple march with a trio, the first and the last movements are rondos set on a large scale, with a wealth of thematic material. As for the overall form, both movements are schematically ABACA where the $B$ and $C$ sections are both multiply subdivided and extended by indicated repetitions and inner returns. The choice of this form is especially conspicuous in the first movement, for Schubert often chose the rondo form for a final movement. whereas in a first movement it is exceptional that the sonata form be overcome by another principle of construction.

The rondo form of the first movement is just as irregular as is the third's. The different materials of the theme and the episodes are clearly differentiated: articulation is at places by composed large caesures and the introduction of new keys. Particularly striking is the contrast between the theme and the episodes: the former is not so much a theme as a motto. It is very short, spanning merely twenty bars, compared to the first episode of sixty-two bars. When it appears again, it is further contracted to ten bars, followed by another episode of forty-six bars. Finally, it takes a shape of thirteen bars, closing the movement.

74 Idem.

75 The title appears at Deutsch as Ungerische Melodie. 
The motto-like theme is distinct from the episodes not only for its compactness but also for its musical material, deepening the accents on its signalling statements. Domokos pinpoints the folk music inspiration clad in subtle artistic attire mentioned by Schönstein in the calmly progressing Andante theme in $\mathrm{G}$ minor. The initial section of the movement can be traced back to a folksong type represented by tunes such as Hej, a mohi hegy borának [Ay, the wine of the Mohi mount], Pártám, pártám [My head-dress], etc. ${ }^{76}$ Apart from the motivic relations with the folksong type, its vocal origin is also supported by the song-like quasi syllabic character of the theme.

In contrast with the theme, the episodes are instrumental in nature. Their starting point is the efflorescent, mature verbunkos. Since the greater part of the movement is made up of episodes, this verbunkos inspiration becomes predominant in the music. Schubert's choice of the unusual form must also be attributed to the fact that the raw material of the movement is the verbunkos. The thematic materials enumerated in the episodes recall brief verbunkos dance movements. As has been seen, these dances may be constructed of two, three, or sometimes more loosely related periods in the verbunkos repertory. Later, several such dances became arranged into longer, suite-like units. In terms of form, the episodes adopt this scheme, creating the illusion that we have a series of different dances. This ostensible enumerating form is arranged into larger units by inner returns. This formal conception also applies to the episodes of movement 3.

The formal skeleton of the four episodes is like this:

a) part B of movement 1 cdde e f c dgg + cadenza

b) part C of movement $1 \mathrm{hijkjh}+$ cadenza

c) part B of movement $2 \mathrm{cdedc}$

d) part C ofmovement 2 fgfhihfg

In movement three the thematic groups are arranged more symmetrically, while in the first the enumerating and repetitive structures are merged more inseparably but the point is the same in both. With the help of the rondo themes and the complex episodes such an overall form is produced in which several returns, simple and varied repetitions outline the model of verbunkos form that is based on small musical units "making up a gradually unfolding multi-part construct". The kinship between the principles of construction is obvious even if we allow that it was realized in a far more rudimentary form in the verbunkos repertory, the source of Divertissement à l'hongroise, than

76 Domokos: Divertissement, p. 8. 
in the work itself. The real appeal of the form of the Schubert work is, especially in movement one where the rondo theme is very compact and functions as a frame or supporting pillar, that hearing the work, we do not perceive the intricate rondo form so much as the diversity of various thematic materials whose enumeration seems spontaneous, throwing the rhapsodic character of the work into deep relief.

b) Integrity, thematic and motivic relations

The form of the two outer movements, the greater part of the composition, possibly needs thematic and motivic relations more badly than any more customary form since the profusion of themes endangers the unity of composition more, despite the connections between certain minor segments. Schubert created the necessary links for the whole of the form and for a movement alike, which integrate the piece without jeopardizing the melodic variety.

As Domokos has pointed out, the materials of the first movement are unified by a single motif, one of the most typical verbunkos patterns, the bokázó. ${ }^{77}$ It immediately appears as the very first musical moment, at the beginning of the Andante theme using the melodic contours of the folksong type Ay, the wine of the Mohi mount, although massively changed, adjusted to its musical environment, removed from its dancing character, slowed down and augmented (Example 28a). Before the closure, it is already doubled, just as at the beginning of the first episode, in its $\mathrm{E}$ flat major section marked "c" (Example 28b). The heads of section "d" starting with bar 29 and section "e" from bar 45 are also based on this motif. Section "f" is practically governed by this bokázó pattern throughout, with the exception that Schubert also varies it: in bar 58 the step is towards the upper auxiliary note ( $E x$ ample 28c). Part "g" starting with bar 71 employs the original form with the lower auxiliary note (Example $28 d$ ). The theme-head of the B flat major part "h" adopts the varied motif and elaborates it (Example 28e). This themehead is a kin to a motif of section "g", too (Example 28d). Section "i" from bar 99 contains both forms of the bokázó, with upper and lower auxiliary notes. The only part of the second episode, and the whole movement, is the D minor section of the episode (Example 28f) in which the bokázó does not play a role, but via the dotted rhythms determining its rhythmic layout, it is the direct continuation of section " $h$ " where this rhythmic pattern as a typical Hungarian motif, too is to appear first (see Examples 28a-f).

77 Idem. 


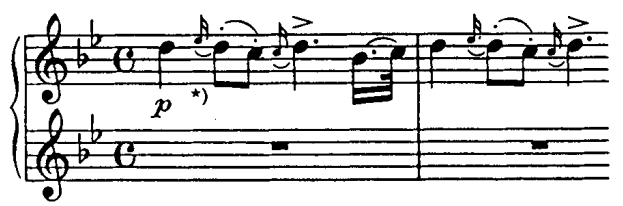

Example 28a: Schubert: Divertissement à l'hongroise, movement 1, bars 1-2
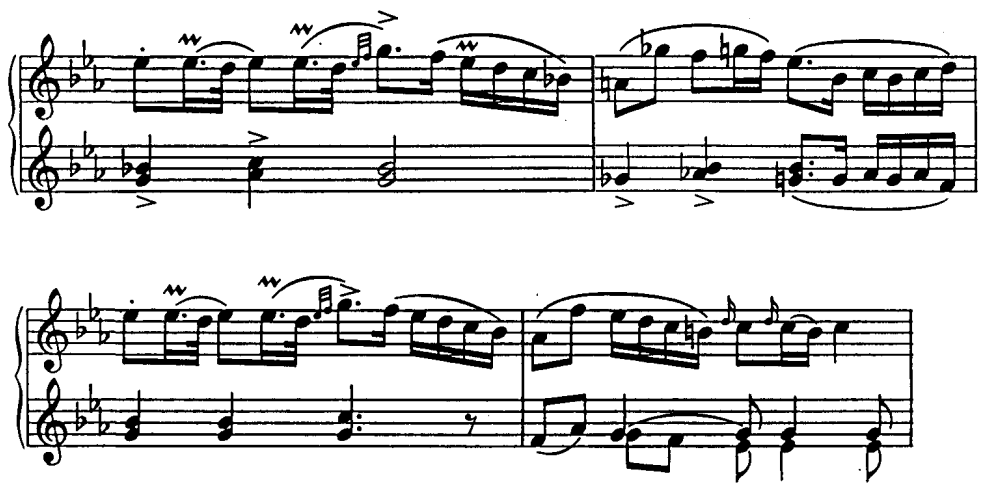

Example 28b: Schubert:Divertissement à l'hongroise, movement 1, bars 21-24
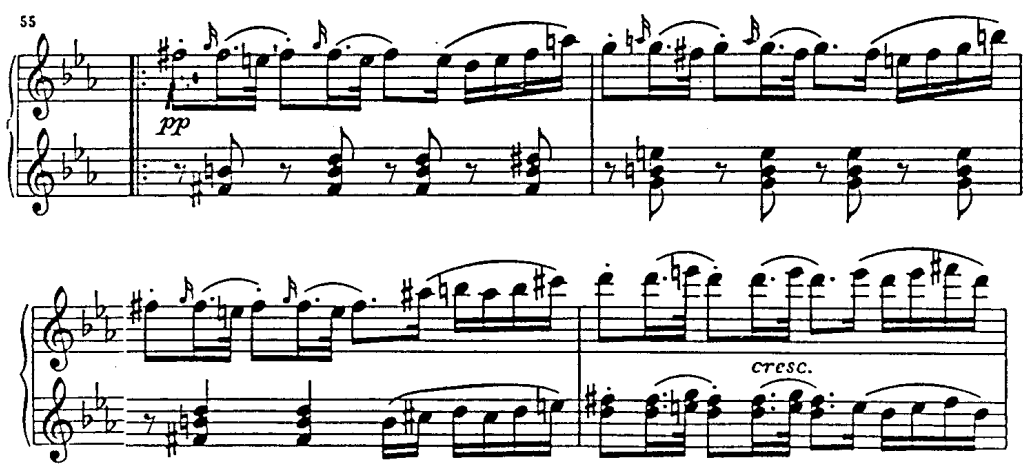

Example 28c: Schubert:Divertissement à l'hongroise, movement 1, bars 55-58

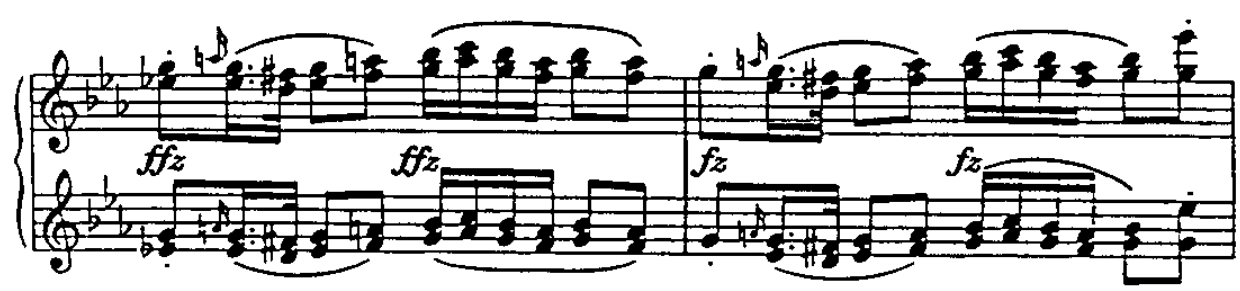

Example 28d: Schubert:Divertissement à l'hongroise, movement 1, bars 71-72 

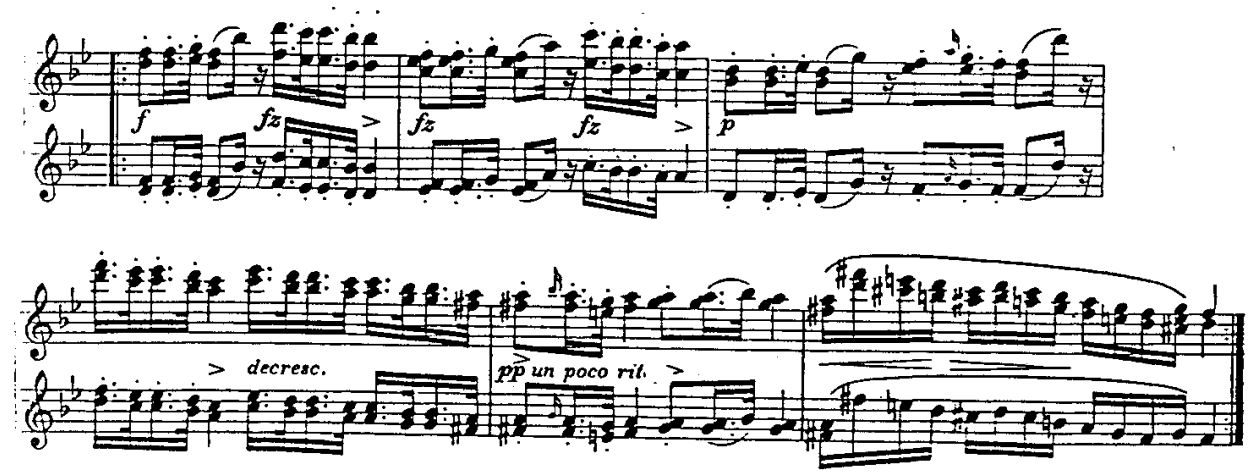

Example 28e: Schubert: Divertissement à l'hongroise, movement 1, bars 93-98 (concerning the first half of the bar 1 see also the second half of the bar 2 of Ex. 28d)

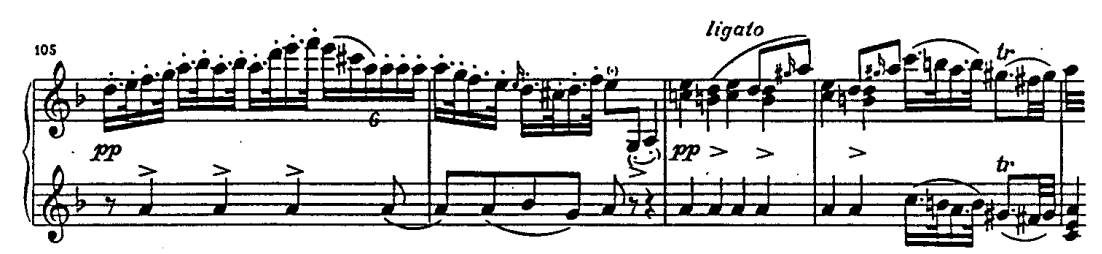

Example 28f: Schubert: Divertissement à l'hongroise, movement 1, mm. 106-109

The motivic core - the bokázó - underlying the entire first movement determines the $\mathrm{C}$ minor main section of movement two as well. The kinship is especially conspicuous in the second half of the march theme, in which the motif appears six times alternately with upper and lower auxiliary notes. The bokázó also appears in the accompaniment of the theme-head, and what is more, in the melody one can also discern a remote variant of it, although the outline of the melody has radically changed, with the rhythmic character remaining constant (Examples 29). It is noteworthy how the relationship between the beginning of the march and that of the second episode of the first movement further reinforces the cohesion of the movements. The rhythm of the two theme-heads is identical, their melodies progess in identical direction: the first bars of both demonstrate the same dominant-tonic relationship and accordingly the fourth interval, while the second bar of the march theme reflects upon the declining third of the episode theme, itself also of marching character (Example 28e).

In the third movement, the bokázó motif only appears in the f sharp minor area reminiscent of the Rákóczi march, precisely in its mid-part, referring thereby to the motivically related moments in movements one and two. 


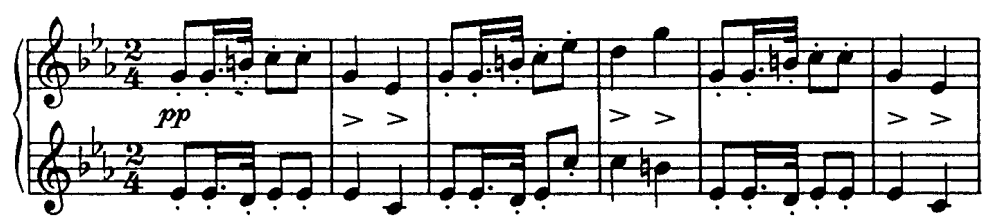

Example 29: Schubert: Divertissement à l'hongroise, movement 2, bars 1-12

Apart from this motivic contact, the coherence of movements three and one is also confirmed by the $g$ minor section of the former's first episode marked " $d$ ", which is actually the condensation or essence of the opening Andante of the work. ${ }^{78}$ Although indirect, the connection between the two themes can be recognized on account of the identical tonality and the simple, cantabile character (Examples 30a, b).

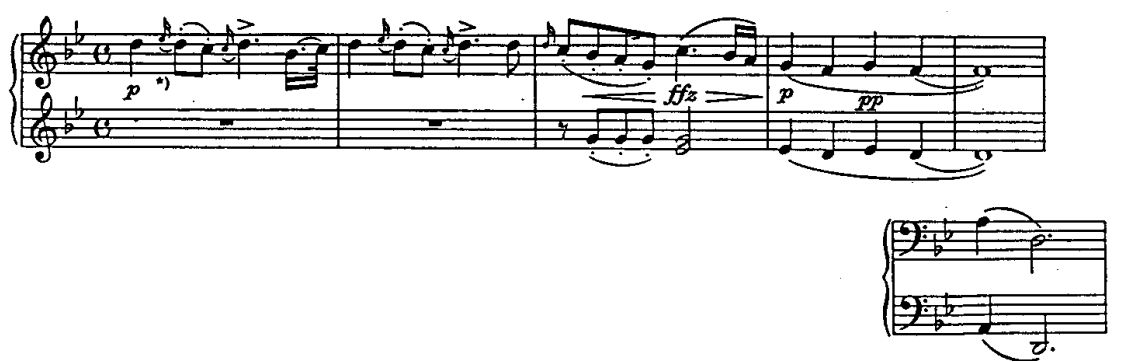

Example 30a: Schubert: Divertissement à l'hongroise, movement 1, bars 1-5 (The leap of the fifth at the end of the line characteristic of the theme and of the folksong type functioning as source appears in the bar 5 of the secondo part.)

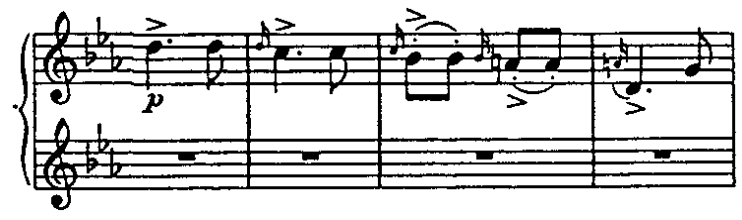

Example 30b: Schubert: Divertissement à l'hongroise, movement 3, bars 101-104

The C minor section (part "c") of the first episode of the third movement further exemplifies the organic motivic construction. It refers back to the beginning of the central march movement. Not only the launching of the two themes is strikingly similar, but so are the march character and common key (Example 31). The stressed fourth step of the theme-head of the $\mathrm{C}$ minor march in movement three is particularly noteworthy because the pendular

${ }^{78}$ Idem, p. 7. 


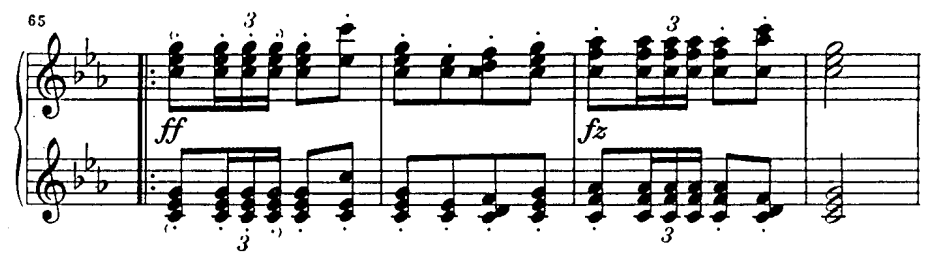

Example 31: Schubert: Divertissement à l'hongroise, movement 3, bars 65-68 (concerning the bar 1 and the first half of the bar 2 see also the bars 1-2 of Ex. 29)

fourth imitating the Hungarian kuruc fourth determines the beginning of the rondo theme borrowed from the Ungarische Melodie, and the already mentioned F sharp minor section of the second episode also begins with an emphatic fourth motif accentuated with a Hungarian-like upbeat. The immediate precedent of the upbeat leading from the lower fourth to the tonic can be found in the D minor close of the B flat major section prior to the F sharp minor "march". Thus, in the closing movement the Hungarian-style fourth motif takes on part of the unifying role that was ascribed by Schubert to the bokázó motif in the first movement (Examples 32a, b, c).

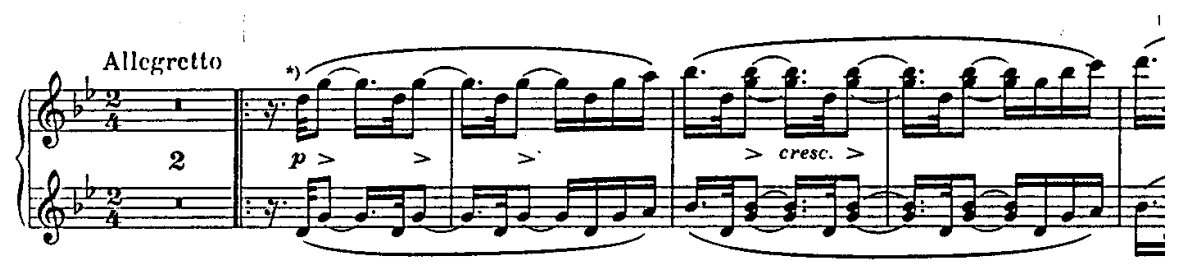

Example 32a: Schubert: Divertissement à l'hongroise, movement 3, bars 3-6
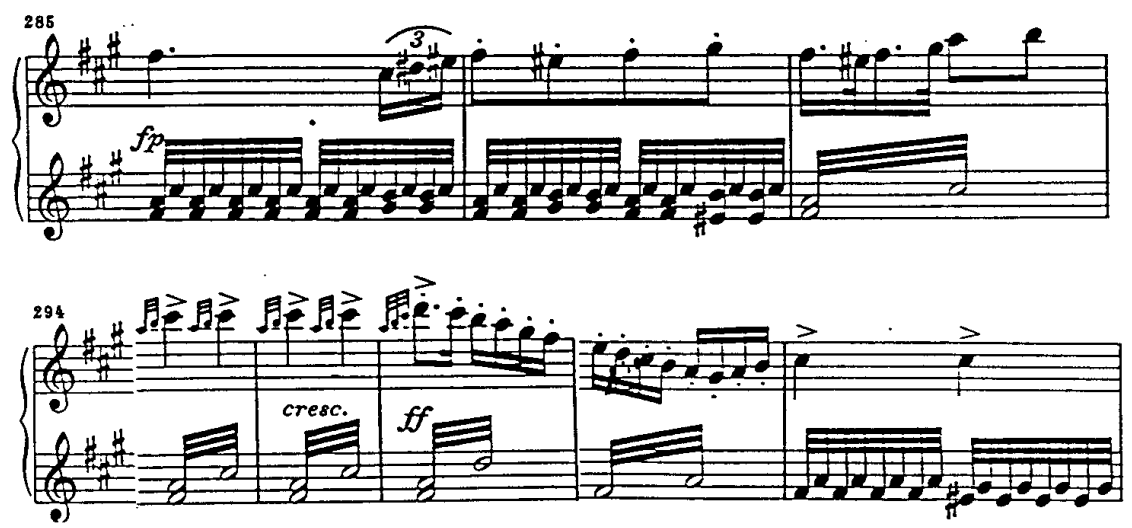

Example 32b: Schubert: Divertissement à l'hongroise, movement 3, bars 288-295 


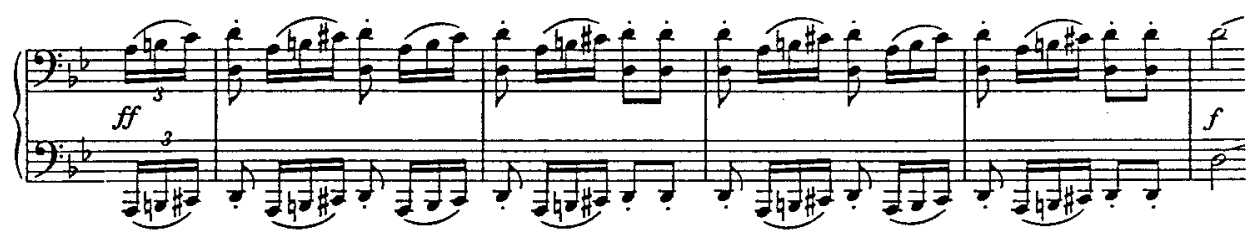

Example 32c: Schubert: Divertissement à l'hongroise, movement 3, bars 252-256

The motivic organization of the movements deserves attention not only because it helps overcome the danger of disintegration implied by the overall form but also because these difficulties are surmounted by the composer mainly using Hungarian motifs. This style hongrois phenomenon is not found in music before Schubert: Schubert does not use the Hungarian element as colouring, exotic marks or "stamps" but organically integrates them into the motivic process. In this way, the Hungarian elements become essential constituents of the music, taking part in variation, development of new materials, contributing to the gradual unfolding of the musical process. As the elements now become part of creation at a more profound level, the Hungarian impression they elicit is even more powerful. That may be why Schubert could bring glory to style hongrois in Divertissement à l'hongroise.

c) Characters, intonations

The successful realization certainly depends on the adequate conception of form and the thematic-motivic work, but it equally depends on if these compositorial tools are appropriate to create the illusion of typically Hungarian intonations. Schubert's work is exemplary in this regard as well. It puts forth thematic materials that are close to some types of mature verbunkos in character. These include the beginning of the first episode of movement one, the E flat major theme (Example 28b) whose rhythmic balance, moderate tempo, stepping-dancing character compare it to the "pliable-cantabile" type of verbunkos characterized by restrained gestures. The $\mathrm{D}$ minor section of the second episode of this movement, by contrast, is closer to the "tight, giusto" type on account of its progressing dotted rhythms and the vigorous dancing motion of the end of bar two (Example 28f).

As regards character and Hungarian intonation, those musical materials in which Schubert supersedes the possibilities offered by the intonation types of mature verbunkos are more intriguing and in some ways more significant. Occasionally he strikes a note which extends them, deepening 
and metamorphosing them, so that they sound, paradoxically, more "Hungarian".

The rhythmic pulse of the rondo theme of movement three refers back to the giusto slow tunes; instead of conjuring up their tightness via a range of differentiated rhythmic patterns, he bases the entire theme on a single (alredy mentioned) pendular motif and its development and variation. Thereby, the Hungarian motif becomes part of the compositional process again, and on the other hand, the periodic division derived from the dancing attitude and character of the original type becomes merged into a single huge thematic flow. Although it is thus severed from the original type, the Hungarian character of the theme is unquestionable as its basic elements, dotted rhythms with ties and the stylized kuruc fourth capture perfectly the Hungarian character (Example 32a).

The irregular but highly inspired Hungarian intonation of the theme derives from the fact that Schubert immediately subjects these elements, that is, the basic motif after all, to motivic development. The constant wandering of the motifs, their search for tonal ways is the vehicle that conveys the fluently undulating, now melancholic, now impassioned character of the theme. This time, however, it is not only an intonation that is represented; the theme is associated with an inner content. The motivic search swerving in new directions all the time transcends into the musical reflection of unending and restless wandering. "Wandern" is an important aspect of Schubert's late work. It comes to flourish in works such as the song cycles to Müller's poems, Die schöne Müllerin and Winterreise, or the Fantasie in fminor for four hands. ${ }^{79}$ In the third movement of Divertissement this content does not quite appear as in the above listed works; precisely for its Hungarian gestures this wandering is more passionate and unbridled than destitute or tragic. In terms of style hongrois, however, it is not these nuances that count but the fact that the Hungarian intonation is capable of conveying contents beyond music in forms of expression typical of romanticism.

Such an expression is reflected in the F sharp minor section of the second episode in movement three. It is hard to define or derive the character of theme from the verbunkos types. A highly militant, explosive aspect of the Hungarian character is at hand here which is not typical of the verbunkos repertory. Domokos suggests that two sources of inspiration are possible to detect in the background: one is the Rákóczi march the printed edition of

79 Kinderman: Schubert' Tragic, p. 75. 
which was already available in Vienna in 1820 and the other a drawing by Moritz von Schwind on a Hungarian subject, Der Ausfall Zrinyis bei Szigeth ${ }^{80}$ Especially the latter demands attention here, for the inspiration of art might explain the well-nigh programmatic character and the dramatic force of the F sharp minor section.

The elements are typically Hungarian. Such are the triplet upbeat leading to the tonic of the minor scale just as much as the dotted turn motif of bar 3 of the theme, which is the diminished variant of the previous bar motivically, by the way; and the accented crotchets with appoggiaturas halting the sweep, which causes the eight-bar period to fall into an irregular Hungarian asymmetry of $3+2+3$ bars (Example $32 b$ ).

Both the rondo theme and the F sharp minor episode present new, so-far unknown facets of the Hungarian intonation, similarly to the Andante of the first movement. In the latter, the vocal source must also have contributed to the fact that the theme shows little kinship with the intonation types of verbunkos. The treatment of the folksong, on the other side, implies the possibility of enriching style hongrois with so-far unusual, new hues and characters. This new character leads to the most sombre, darkest minor tonal areas of the Hungarian intonation. The mournfulness of $\mathrm{G}$ minor turning into $\mathrm{D}$ minor at times for lack of a leading note is underlined by the powerful emotional effect of the subdominant chord in bar 3 of the theme. This profound melancholic intonation is in part attributable to the pensive character of the theme stemming from the fact that what the theme presents is not so much a continuous melody as the repetition of melodic fragments. These are interrupted by composed ritardandos, producing eventually a musical material of slight rubato character (Example 30a).

The freedom of tempo choice subtly hidden in the texture and the melancholic character are two features that link the theme with the "free, rubato" type of verbunkos, even if it cannot be disregarded that the intonations derive from different sources: vocal for the theme of Divertissement and instrumental for the verbunkos. Schubert also underscores this similarity by introducing the other two statements of the Andante theme with a combination of violin solo imitation and a "cimbalom tremolo" which clearly relies on the verbunkos type stylizing Gypsy performance (Example 33). These two kinds of musical materials related in character produce such an elevated "puszta (waste) sound" evoking sentiments of "distance" and "freedom"

80 Domokos: Divertissement, p. 9. 


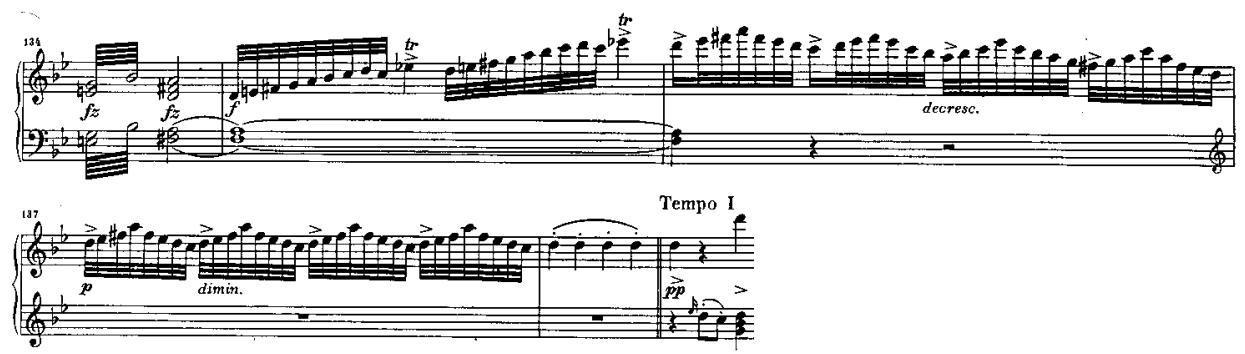

Example 33: Schubert: Divertissement à l'hongroise, movement 1, bars 134-139

which proves that Schubert was able to create not only a Hungarian style but an authentically Hungarian musical atmosphere. The fullest exploitation of the potentialities of the Hungarian intonation, already an ambition with Beethoven in a rudimentay form, promotes the work to the paragon of style hongrois. On account of its thoughful form conception and motivic organisation, Divertissement à l'hongroise is such an over-particular composition that, although expressely named a Divertissement, would deserve the title Hungarian fantasy conveying more serious intentions.

\section{Style Hongrois in other Instrumental Works by Schubert}

The form principles rooted in the verbunkos material, the inclusion of Hungarian elements in the organically built motivic process and the deeper understanding and enrichment of the intonations - these three aspects of Divertissement à l'hongroise - determined Schubert's attitude towards style hongrois in a novel way. The presence or absence of any of these three factors might help deliberate which Schubert works show unambiguous Hungarian influences. A knowledge of Divertissement itself helps this examination. Though many works are named in the Schubert literature as compositions using Hungarian elements and showing Hungarian characteristics, only a few Schubert works can be declared to display the Hungarian influence openly, in view of the abovesaid.

These works are as follows:

String quartet in G minor (D 173) 1815, movement 4

String quartet in A minor (D 804) 1824, movement 4

Octet in F major (D 803) 1824, movement 6

Fantasy in C major (D 934) 1827

Symphony in C major no. 9 (D 944) ? 1825-8, movement 2

String quintet in C major (D 956) 1828, movements 3, 4 
Another three works may be considered as showing some Hungarian influence but their Hungarian character can be questioned:

Trois marches militaires (D 7339) 1818, nos. 1,2

Rosamunde - ballet inserts (D 797) 1823

Moment musical in F minor (D 780) op. 94 no. 3, 1823

Some motifs and melodic fragments of these marches and ballet musics may create Hungarian impressions but judging these is subjective and hard to verify by the analysis of musical factors. These Hungarian elemnts are also only tools of surface coloration at places, hence do not belong among the most typical style hongrois works of Shubert.

The $F$ minor moment musical is intriguing for it enumerates several features that are regarded Hungarian. Such are the constantly present, accented, repeated crotchets also involved in Schubert's other Hungarian-like themes, e.g. the F sharp minor episode of Divertissement or the theme of the second movement of the Symphony in $C$ major, which break up the periods into short two-bar units. The work's articulation and periodical construction is also striking, reminiscent of the enumerating structure of verbunkos movements. It is, however, also to be remembered that Schubert's piece is far more densely structured motivically, hence the loose enumerating principle is only partly brought to bear. All in all, the $F$ minor moment musical does not produce a convincing Hungarian impression, though some of its features may derive from verbunkos material Schubert knew. It is illuminating to know that when it was first published in a mixed collection, it was titled Air russe. ${ }^{81}$ Even if the name derived from the publisher and not Schubert himself, it sheds ample light on the fact that the work's character was not indubitably understood as Hungarian by Schubert's contemporaries either.

Bellman also remarks that Moment musical in F minor as Schubert's first style hongrois work is still experimental in nature. ${ }^{82}$ That is, however, erroneous for the composer's earliest piece displaying features of a Hungarian style is the $G$ minor string quartet. The rondo theme of the quartet's fourth movement contains several typical Hungarian elements. This theme is a far better example of Schubert's early Hungarian style than is the Moment musical. What most typically characterizes this early Hungarian style is the lack of the composer's original, individual style hongrois. In the quartet movement Schubert appears to reflect upon Haydn's Hungaricisms. The

81 Feil: Analyses, p. 117.

82 Bellman: Style Hongrois, p. 162. 
theme itself, although lacking frequent verbunkos patterns, alludes to the characteristic features of Haydn's Hungarian style at several places. For example, it adopts Haydn's frequent mannerism of performance, the simple appoggiatura. He also employs rolling figurations built out of repeated pairs of bars $(2 \times 2)$ to extend the material. (Example 34$)$. This typical instrumental motif that constitutes the end of the theme is seemingly a tiny irrelevant moment but in the central quasi development section, Schubert also unfolds a longer stretch of music from it, which lends it more emphasis and reinforces the Hungarian character of the development. In addition to the different appearances of the theme, the episode leading to the second thematic material is also noteworthy for its Hungarian-Turkish figured motifs found sometimes with classical composers (Example 35).
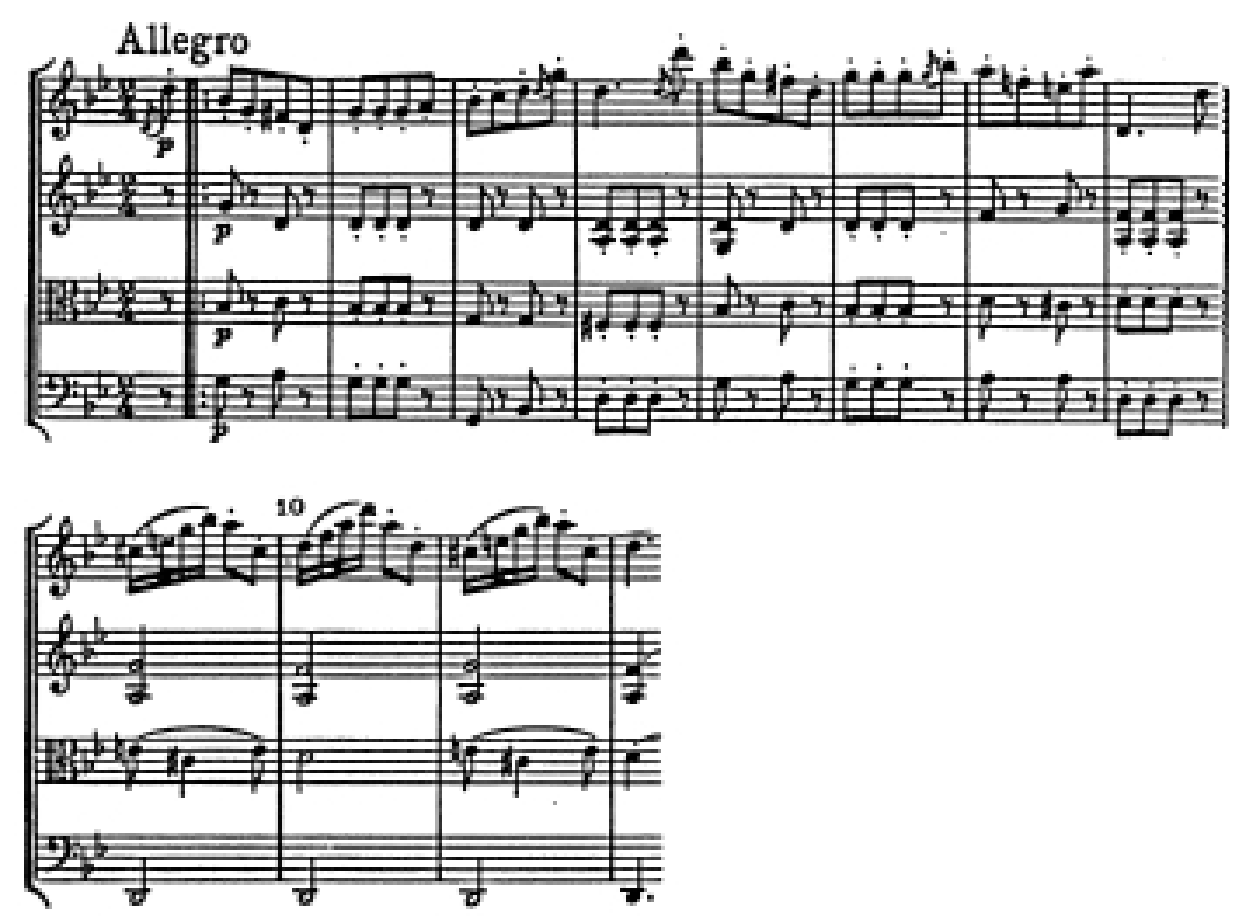

Example 34: Schubert: String Quartet in G minor, movement 4, bars 1-12

This early work is sharply marked off from the other compositions displaying Hungarian influence that were composed about a decade later and that are among Schubert's most typical style hongrois works. 


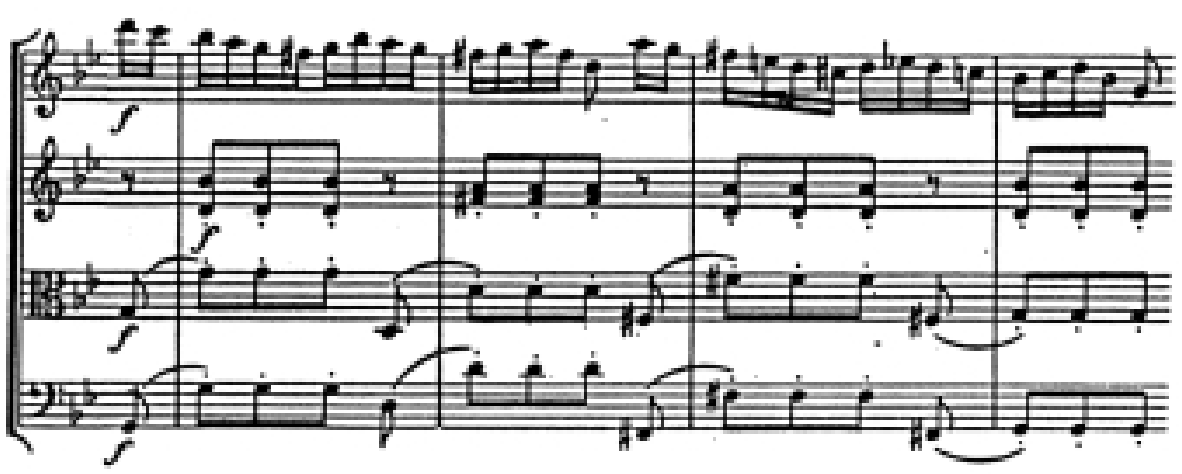

Example 35: Schubert: String Quartet in G minor, movement 4, bars 33-36

There is another quartet widely recognized as influenced by Hungarian elements: that is the Quartet in A minor, again the last movement attesting to the Hungarian influence. Bellman's analysis reveals that he identifies the main theme with the thematically Hungarian musical material, chiefly for its rhythmic elements and asymmetric construction. ${ }^{83}$ The main theme is not a regular eight-bar period but consists of ten bars comprising two five-bar half-periods. Though the number of bars is irregular, this construction is not quite identical with Schubert's openly asymmetrical patterns disrupting the order of musical phrases which can occasionally be found in the pieces containing Hungarian elements, such as Divertissement à l'hongroise.

Subjective as it may sound, the main theme rather displays some generally folkloristic, rustic character. In the knowledge of the rest of Schubert's style hongrois works, one may perhaps question the Hungarian character of the theme on account of the combined presence of the relatively fast tempo character and the major tonality. This theme type is not typical of the composer's Hungarian themes which are normally in minor keys. Wherever themes in major keys appear, e.g. in Divertissement à l'hongrois, there the tempos are more restricted and the musical material is closer to the verbunkos tunes both in motifs and in rhythm. The only faster Hungarianlike theme in a major key is in Fantasy in C major but the figurations he used rooted all in the motivic stock of verbunkos. It is otherwise in the main theme of the finale of the A minor quartet, which therefore cannot be taken for a typical example of Schubert's style hongrois.

83 Idem. 
By contrast, the second theme of the movement in $\mathrm{C}$ sharp minor is far more typically Hungarian. Its progressing dotted rhythms can be retraced to the "tight, giusto" type of the verbunkos, but this typical verbunkos intonation appears here ennobled, possibly because the theme itself is stylized. On the one hand, its tempo is faster than that of the slow verbunkos dances, and on the other, its melodic writing displays less sharp, dancing gestures than a smooth rounded form. Thus, the type does not appear directly but sublimated; this time, the intonation is more restrained than the original, instead of being more vigorous. There is but a slight allusion to the pathetic intonation by the upward thrusting then declining fourth motif, which lends the theme its distinctly Hungarian character, and which is to appear in bar 3 transformed into a kuruc fourth motif. This nobly elevated intonation derived from the verbunkos allows the composer to convey new expressive qualities in his music.

It is the "tight, giusto" type of the verbunkos again - precisely its more dance-like, invigorated form - that underlies the second movement of the $C$ major symphony, in which the Hungarian influence is detectable in the A minor theme and in the first musical section of the movement also in A minor. The connection to the tight slow dances is suggested first of all by the restrained, dancing lilt of the theme. Besides, the emphatic presence of the dotted rhythms is also conspicuous. The tools are stylized, with only a few motivic moments suggesting the Hungarian character. These include the turn motif in dotted rhythm in bars 1-2 and the ensuing fourth leap to the upper tonic, or another shape of the turn motif in dotted rhythm in bars 6-7. The latter motif, frequently found in the verbunkos tunes, is applied by Schubert in a manner that is quite alien to the source material: repeated across two bars. The obstinate melodic motif and the melodic outline of the theme and its finely wrought character all add up to prove that Schubert used the verbunkos source in an utterly stylized manner. Thus the intonation suggested by the theme is also abstract, as in the case of the $\mathrm{C}$ sharp minor theme of the Quartet in A minor. The typically pathetic, heroic character of the "tight, giusto" type gets enriched here with more sombre, dramatic colours. This more powerful dramatic force is manifest in the stubborn repetition of motifs and obstinate repeated tones, interlacing not only the theme but also its continuation, the entire A minor section.

In addition to the intonation - which is again more intense than that of the verbunkos on which it drew for inspiration - the theme's asymmetrical 
construction is also to be noted as a Hungarian influence, not independently of the motivic structure. Its first three-bar asymmetrical unit is formed by Schubert blocking the flow of music with the repeated stressed crotchets and reshuffling the regular metric pulse of the period here. From then on, the theme is built from $3 \times 2$ bars, eventually producing a 9-bar unit, the first part having 3 and the second having 6 bars. Similarly irregular is the second statement of the theme, but it is shorts: seven $(3+4)$ bars. Schubert's handling of asymmetry is remarkable in this movement not only because this element influences the whole of the musical process ${ }^{84}$ - hence it plays a fundamental role in the composition as a Hungarian element - but also because it is conveyed by a motivic element that influences the character, that is, the Hungarian intonation of the movement. This is the motif of repeated crochets, intensifying dramatically the pathetic character derived from the slow verbunkos. The movement's metric, motivic and intonation levels interact more intensely, hence the Hungarian influence is more complex and concentrated.

While in the slow movement of the $C$ major symphony this influence is mediated by the verbunkos-based intonation, motivic content and asymmetrical phenomena, in the last movement of the Octet in F major quite another aspect of Schubert's style hongrois gets into the fore. The lively finale is preceded by an introduction in Andante molto tempo, which returns once before the coda. This slow introduction shows Hungarian influence, but the musical tools used are unusual, hence it displays no tight relation to the verbunkos repertory passed down to us in writing. Schubert embosses a single musical factor in it - sound or instrumental effects - and via these peculiarly elaborated sound effects he evokes Hungarian reminiscences. The first effect is the F note starting pp on the low strings and gradually becoming louder, further intensified by the cello tremolo. Against this sombre sound background starting from naught as it were, the tutti of the rest of the parts enter with an overaccentuated dotting, whose value as a Hungarian gesture is more important than its mere rhythmic quality; the more so, as the regular pulsation of the music is hardly audible and as the forte stresses the beginning of the motif in dotted rhythm. The constantly fluctuating dynamics is especially important for the sound. Following the dotted rhythms like exclamations, the musical surface calms down and reaches the first halt via a slow descending scale passage, from where another tremolo motif leads over to the repetition of the previous musical material at another tonal level (Example 36).

${ }^{84}$ Steinbeck: Schubert Sinfonien, p. 654. 


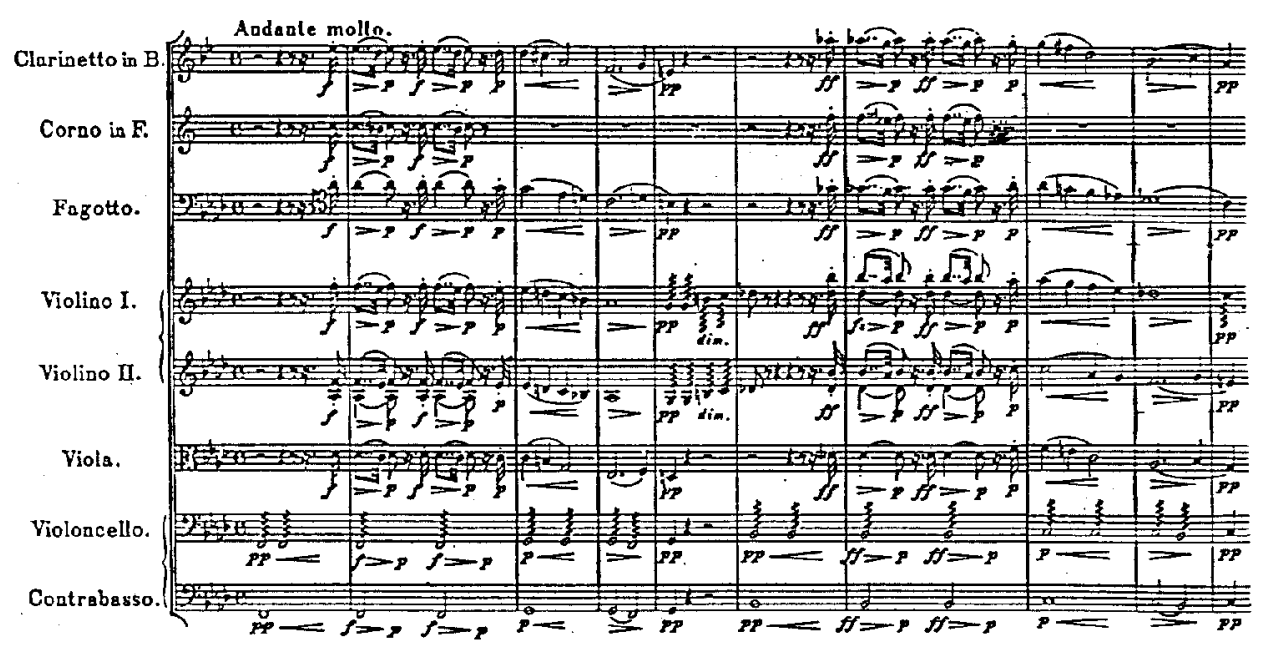

Example 36: Schubert: Octet in F major, movement 6, bars 1-9

The acoustic context thus produced evokes an aural experience at the back of which the effect of live music as played authentically by Gypsy bands can be felt. This impression is reinforced by the return of the slow introduction in which the effects are further enriched by the virtuosic, improvisatory solo of the violin with Gypsy-like ornaments. At this point, the Andante molto is closest to the "free, rubato" type of the verbunkos, which also stylizes the performance of Gypsy bands. With the help of a musical material stylizing the passionate Gypsy performance and Gypsy band sound, an intonation is achieved beneath which one may spot a more profound emotional and well-nigh programmatic content: and this is hard to imagine without the personal emotional background that influenced Schubert's attitude to Hungary. This dramatic music of the composer perhaps also implies the image of the tempestuous Hungarian scenery: a scenery that showed him in 1818, and even more in 1824, its savage, "dark minor" face "in the depth of Hungary".

The sound that constituted the core of the Hungarian influence in the Octet in F major becomes an important factor of style hongrois in the Fantasy in $C$ major. In the complex work of movements joined attacca, the slow introductory Andante molto in $\mathrm{C}$ major and the Allegretto in A minor display Hungarian characteristics. In the slow $\mathrm{C}$ major section the allusion is rather indirect. It only affects the beginning and closing bars instead of the whole. Similary to the F major Octet, the peculiar sound conveys the Hungarian 
characteristics in the initial bars determined by the tremoli of the piano imitating a cimbalom accompaniment. This accompaniment type has a Hungarian flair because owing to the incessant tremoli, the musical texture is actually devoid of rhythm, "free". The Hungarian colour is made unambiguous when the violin enters. The beginning of the violin solo is just as free and hardly mensurated as is the accompaniment (Example 37). The many long notes render the music incorporeal, soaring, therefore the $6 / 8$ metric indication alien to the Hungarian character is not disturbing, at least as long as the basic pulse of the music does not come to a head.
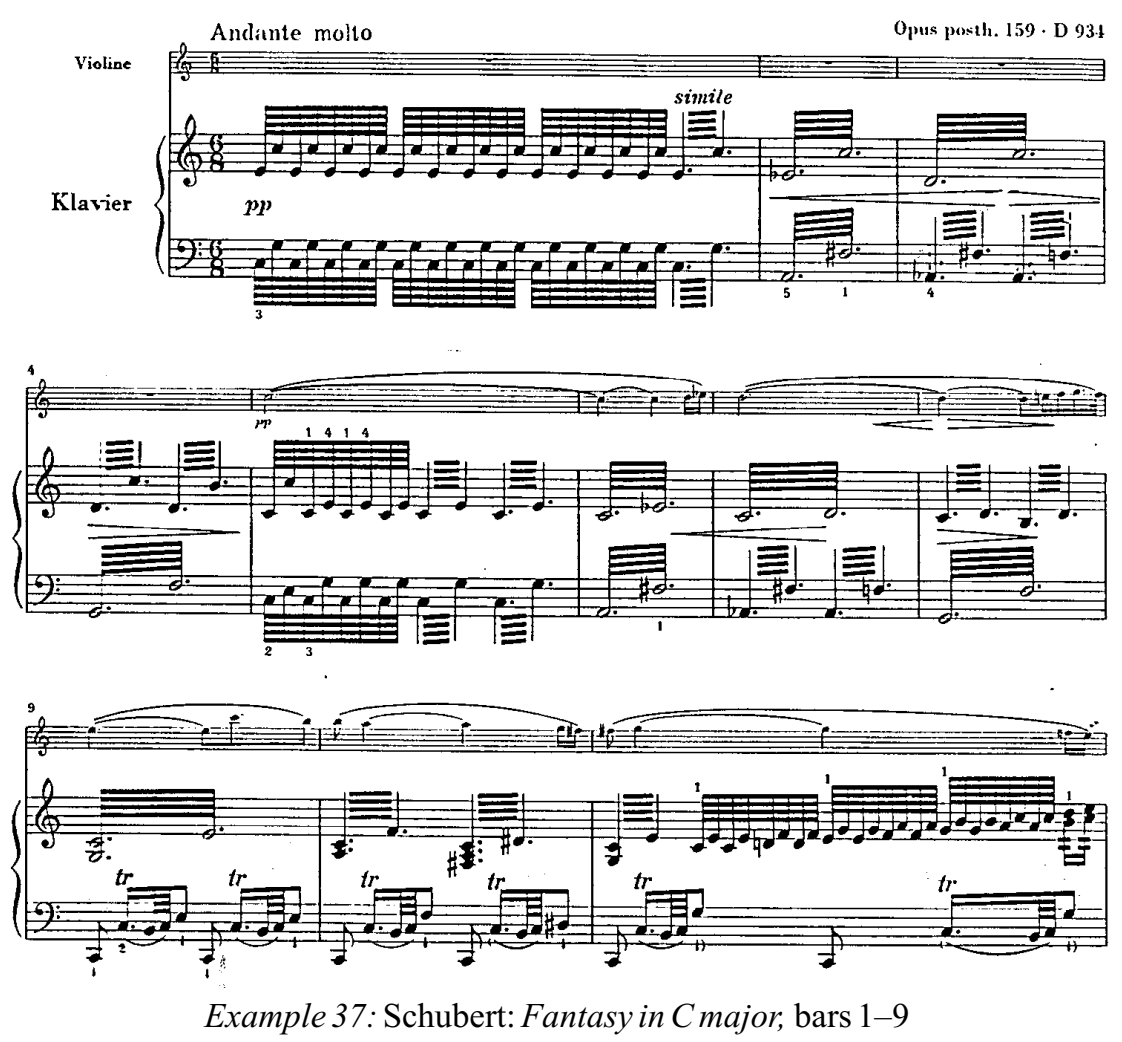

The characteristic launching of the introduction can hardly be imagined without Hungarian musical experiences, even if another important musical factor, harmonization, is fairly removed from verbunkos and the primitive concept of harmonic function found in Gypsy musicians already in the opening bars. Schubert's harmonic construction reflects upon the whole of the work at this point: in his analysis Hinrichsen explains how the bass steps out- 
lined by the first few chords comprise the tonal design of the work like in a motto. ${ }^{85}$ This largely enhances the stylization of the first few bars with Hungarian allusions, but the verbunkos as the source of inspiration at the background remains obvious. This is also confirmed by the end of the slow introduction ending up in a Gypsy-like violin cadenza taken on by the piano playing the role of the cimbalom as well (Example 38). This part of the Andante molto suggests the Hungarian intonation by referring to the "free, rubato" verbunkos type.

The obvious function of the Hungarian passage is to introduce, to prepare the next Hungarian-like theme whose fast tempo, sharp melodic segments - most characteristic of which being the fourth-leaping theme-head expanded into a seventh leap in the second half of the period as well as the tritone leap (between bars 3-4) - remind the listener of the most temperamental friss tunes of the mature verbunkos. Just as in several other instances, the massively stressed pendular motif in the accompaniment derived from the main theme renders the Hungarian influence even more obvious. The second $\mathrm{C}$ major section of the theme is an even more typical friss tune: it is characterized by more contrastive rhythms and virtuosic, rolling figurations (Example 38).

Studying the relation between the slow introduction and the fast main section, one may jump to the conclusion that Schubert represented here the slow-fast form so typical of the verbunkos. The analogy, however, is not so evident. The slow and fast tunes of a verbunkos are equivalent movements joined like in a chain or suite. In Schubert's work, the slow part is merely a preparatory part to the movement in irregular sonata form resembling a first movement. A typical feature of the verbunkos form - speeding up - is, however, detectable throughout the Hungarian parts of the work. This quickening of the tempo has three stages: the first is represented by the Hungarian sections of the slow introduction, the second stage is implied by the appearance of the Allegretto theme which, as the main theme of the sonata, returns several times, and the third stage is the extended closing section fulfilling the function of the coda, also acting as the introduction to the next part in the manner of a slow variation movement. Though no separate tempo indication is added here, based on the constant motion of semiquaver passages, it recalls vividly the virtuosic friss tunes whose perpetuum mobile-like texture often marks the last station in the acceleration of tempo in a verbunkos

85 Hinrichsen: Schubert Kammermusik, p. 500. 

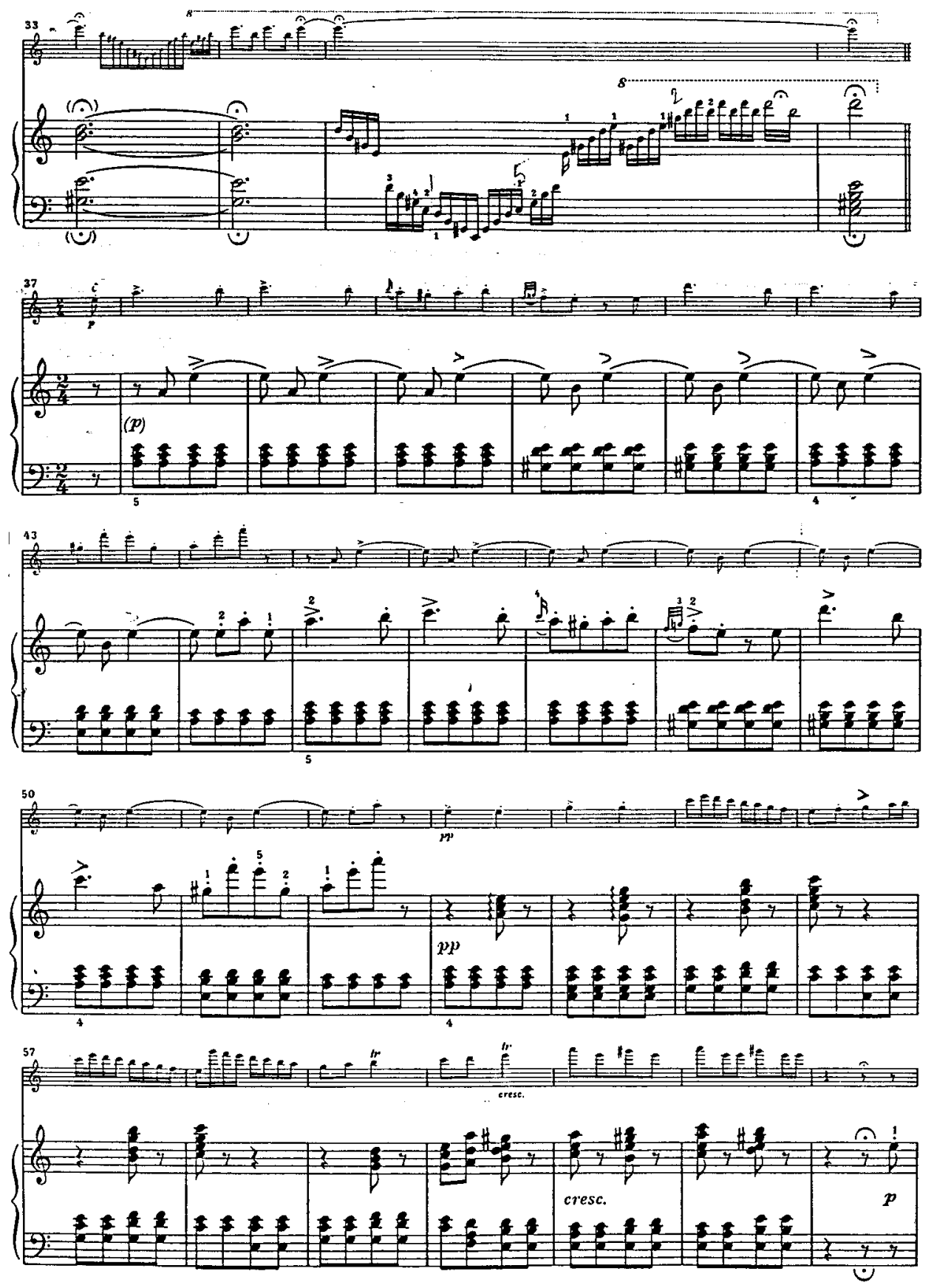

Example 38: Schubert: Fantasy in C major, bars 33-62 
movement series. In addition to that, the semiquaver passages also alludes to the closing figuras with their structure of repeated pairs of bars also accented by the augmented turn motifs derived from the theme-head as counterpoint (Example 39).
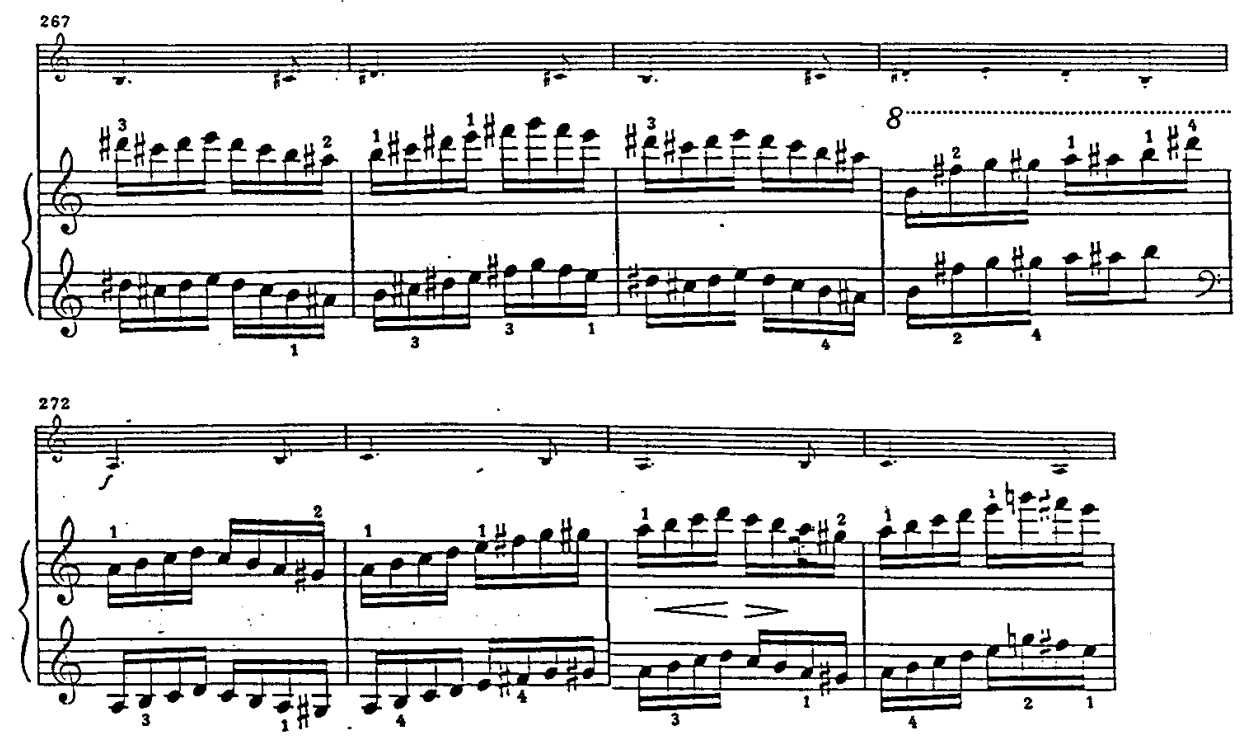

Example 39: Schubert: Fantasy in C major, bars 267-275

Thus, at the central points of the structure, a scheme of speeding up probably traceable to the lassú-friss-figura pattern of verbunkos can be discerned, which, however, only appears covertly as it merges with the principle of the sonata form. Consequently, the Hungarian sections are interrupted by such contrastive musical materials devoid of Hungarian features as the two areas of the extended second theme.

Acceleration as a principle of form belongs to the core of verbunkos music. The combination of this principle with large-scale musical forms can be observed in the $C$ major quintet. Although analysts usually only mention the Hungarian influence in connection with the fourth movement, the third movement is at least as relevant. It is not the fast Scherzo in 3/4 that demands our attention here, but the contrasting Trio, in which the metric indication changes from $3 / 4$ to $4 / 4$ and the tempo slows down to Andante sostenuto. The appearance of the slow tempo character and the dotted rhythms turns the theme of the Trio into the strongly stylized variant of a "stately" verbunkos 
tune (Example 40, bars 1-4). The intonation of the entire formal section is sombre, gloomy, thought not always in minor tonality: it is a manifestation of the "brooding-gloomy" Hungarian intonation, its melodic aspect emphasized solistically, which is known from the Octet in F. Most intriguingly and perhaps not accidentally - some moments of the Trio are thematically related to the Hungarian section of the octet (Example 36). The Hungarian opening gesture embodied in the dotted rhythm is the same in both, even though the rhythmic values are different. Also similar is the slow descent and arrival on the long dark-hued chord after the dotted rhythms. Even the tonal arrangement of the two materials is similar: the first bars are repeated in both cases at a tonal level a fourth higher (Example 40).

The thematic analogies indicate that in both segments we have the different manifestations of a Hungarian intonation typical of Schubert. What also ties the slow introduction of the octet and the Trio of the quintet is that both reflects the experience of having heard the live performance of Gypsy musicians. This feature can be captured best at points of the Trio where the string ensemble imitate the primitive but resounding hallgató ["listening", slow Hungarian popular song] cadence of Gypsy bands (Example 41).

Typical sound, typical intonation, typical thematic type: these are the distinguishing marks of the lassú [slow] that takes shape in the Trio. The next station, the friss tune appears as the main theme of the fourth movement - as possibly Schubert's most effective Hungarian-like theme. Its rhythmic basis is the syncopated accompaniment, upon which the typically Hungarian tune is built consisting of three two-bar units. The first uses typical verbunkos patterns. The second earns its Hungarian character from the appoggiaturas, the third from the motif-repeating, dancing, leaping dactyls (Example 42). These elements determine the basic character of the theme, which is wilder than even the most tempestuous verbunkos friss tune. Here, as often with Schubert, we witness the intention starting with Beethoven to mediate more intense and powerful emotional contents through the Hungarian intonation.

The clue to the expressiveness of the area determined by the main theme lies in the fact that the theme serving as the starting point is not a closed period but an open musical material of diverse motifs liable to further development. Schubert does expoit the motivic possibilities and breaks up the theme immediately after its presentation and shifts it to various tonal levels, before beginning to vary and spin on its tiniest motifs (Example 43). In this way, 

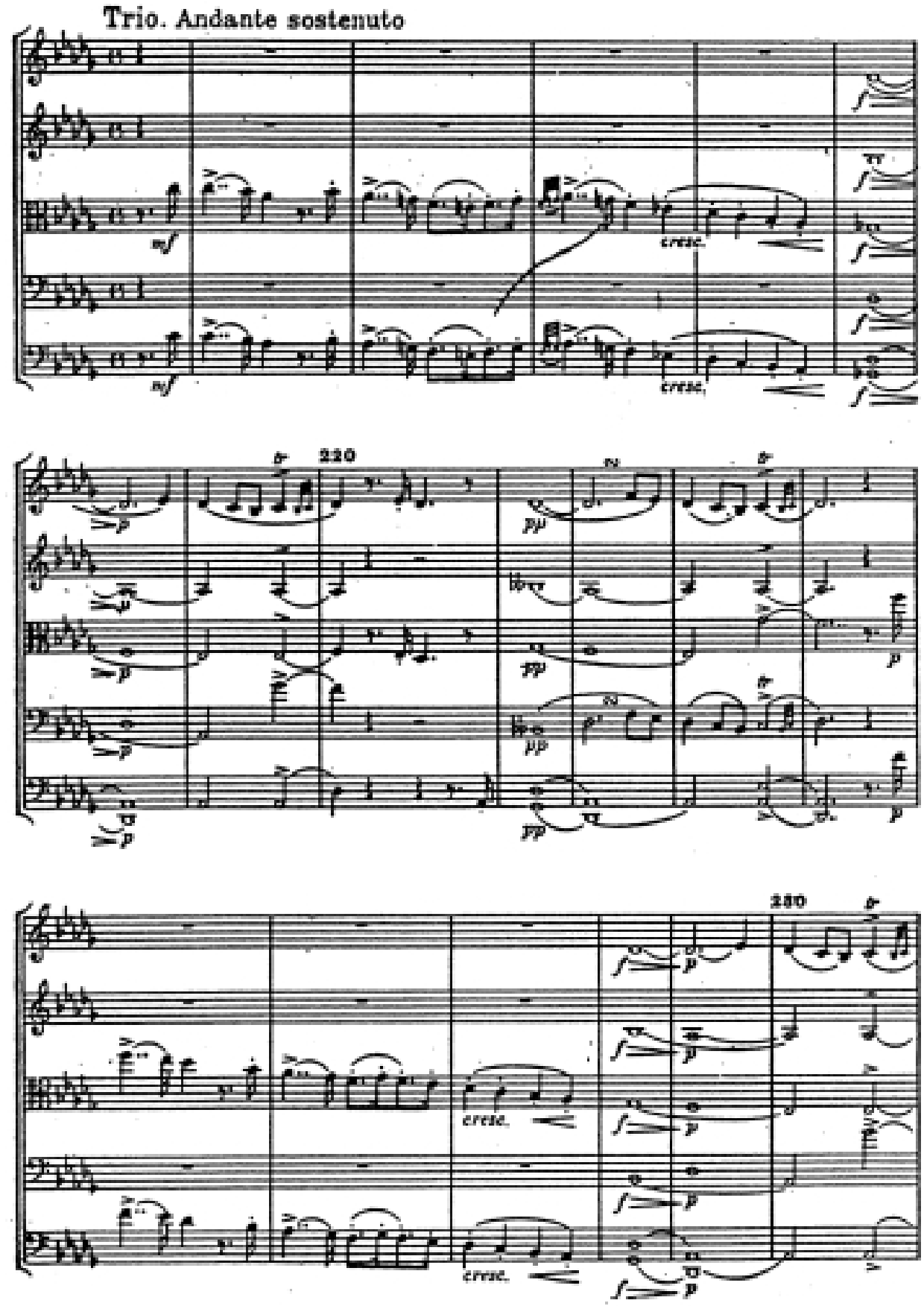

Example 40: Schubert: String Quintet in C major, movement 3, Trio, bars 213-230

(see also Ex. 36) 


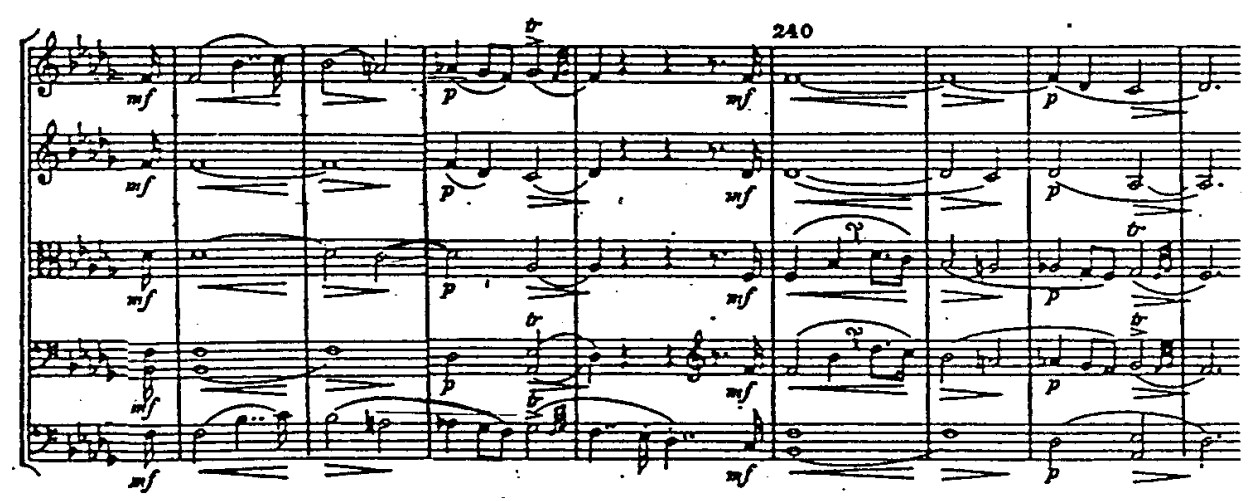

Example 41: Schubert: String Quintet in Cmajor, movement 3, Trio, bars 236-243

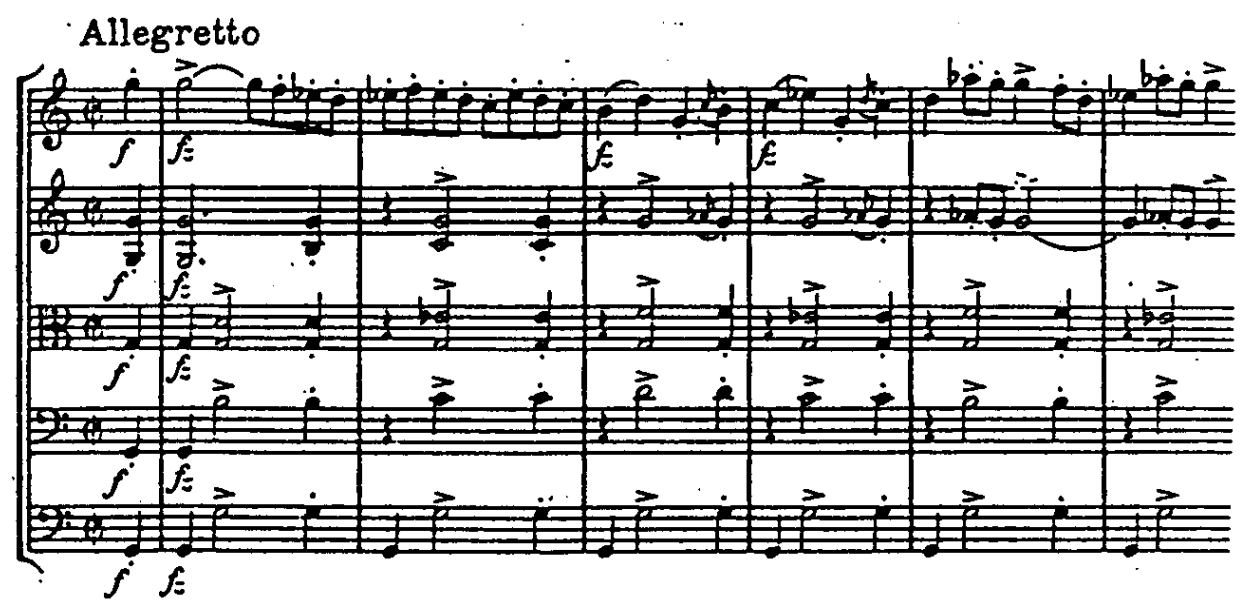

Example 42: Schubert: String Quintet in C major, movement 4, bars 1-6

gradually and unnoticed, the area of transition unfolds from the material of the main theme. Schubert therefore ascribed motivically essential role to the Hungarian elements; he integrates them into the musical process just as it was seen with Divertissement à l'hongroise. Schubert also managed to increase the tension inherent in the rhythmic character of the theme by concentrating the motifs, at least up to the moment when the condensation begins to dissolve motivically to prepare the second theme whose Viennese promenading character is a real contrast to the main theme, and hearing which, one cannot help recall Schubert's letter longing after Vienna from Hungary.

Even more consistent and concentrated elaboration of the Hungarian motifs of the theme can be studied in the development section of the move- 

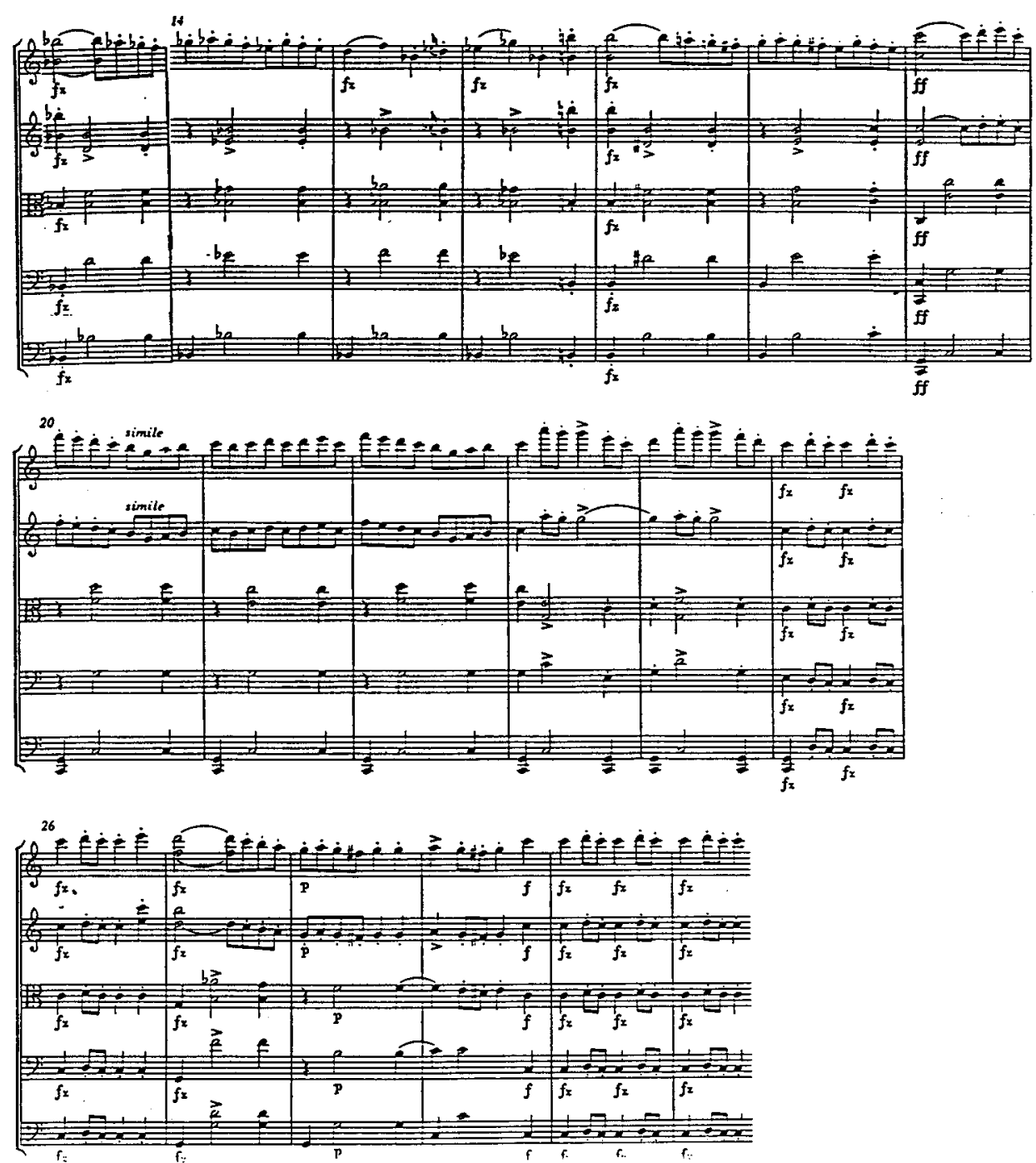

Example 43: Schubert: String Quintet in Cmajor, movement 4, bars 13-31

ment where motivic work is restricted to the first and third motifs of the theme. In this part, the intensification seen in the area of the main theme reaches an even higher point of tension. Schubert places the motifs on a highly unstable, constantly moving tonal ground, thus for a while tension comes from the incessant confrontation of various keys (Example 44). At one point, the composer cannot further enhance this tension unless he brings in another musical factor in support. This factor is rhythm, sharpened and agi- 

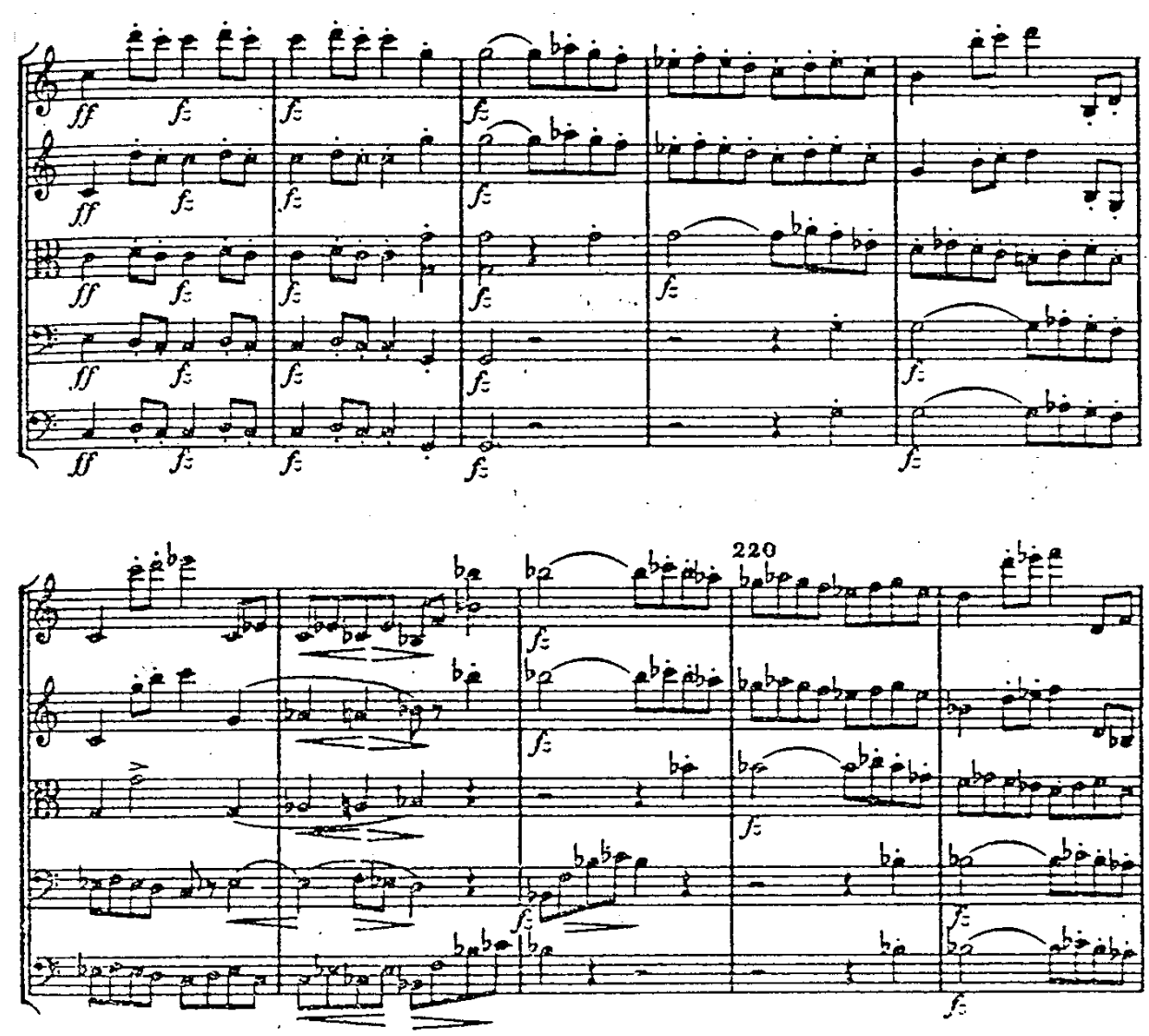

Example 44: Schubert: String Quintet in C major, movement 4, bars 212-221

tated by constant dotting. Dotting, as a Hungarian element, organically adjusts to the Hungarian-like theme.

After this extensive development section built of the materials of the main theme the main theme does not return, so it can be stated that the friss theme undergoes constant intensification. The final stage of this process is the coda in the manner of a "2nd Friss" or Figura where Schubert requires Più allegro tempo. The ecstatic, virtuosic finale character of the theme is also bolstered by the fact that the texture is built on constant quaver motion for a long time and is of the perpetuum mobile type as is the close of the A minor section of Fantasy in C major (Example 45).

To sum up, it can be concluded that intensification as a musical, dramaturgical tool in the Hungarian sections serves as the immanent, hidden 


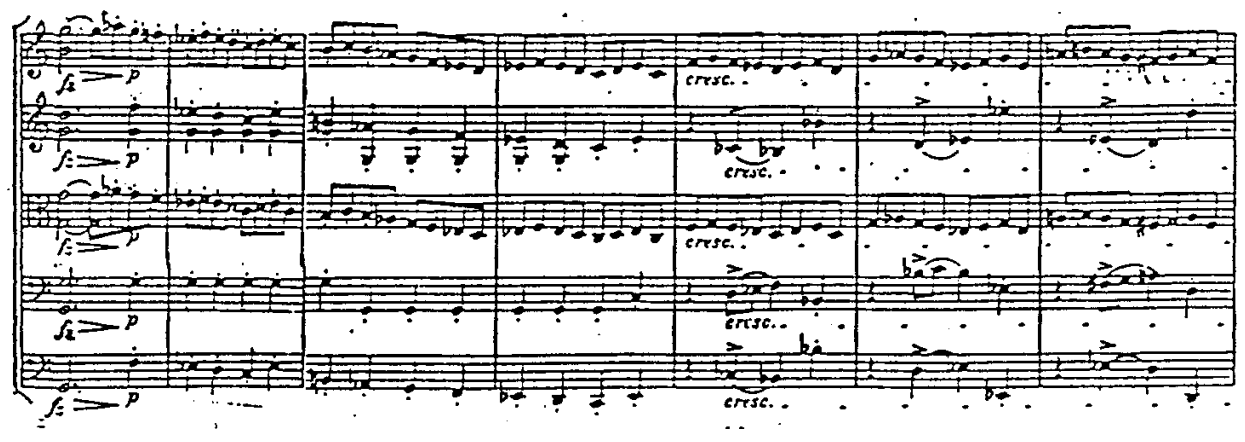

Example 45: Schubert: String Quintet in Cmajor, movement 4, bars 370-376

program of the movement. But this is not the only reason why it belongs to the Hungarian stratum of the movement, and the whole work, but also because the form built from gradually accelerating parts is one of the most typical characteristics of the verbunkos. The principle of intensification prevalent in the second half of the composition permeates the musical process with a Hungarian idea. Schubert again reveals a profound understanding of the Hungarian music, abstracting its essential features (form, motivic stock, intonations) and revaluating them at a high level of art music. These are the aspects that render Schubert's Hungarian style works saliently important in the historical development of style hongrois and trail-blazing for the later phases of romanticism.

\section{Summary}

Style hongrois appears differently in the work of Weber and Schubert, these two great masters of early romanticism.

In Weber's works, the Hungarian influence is not so diverse and possibly less significant than in Schubert's who applied style hongrois in a masterly manner in his main compositions as well. In Weber's oeuvre the Hungaricisms are rather peripherical; the detectable Hungarian moments are usually confined to little known works not counted by music history among his best output.

That does not mean to say that the mentioned Weber pieces bear little relevance to the historical and stylistic investigation of style hongrois. First to stress are the pieces in which the Hungaricisms are set in a special context, mixed with other exotic elements, producing a peculiar, partly isolated island in the style hongrois of the first decades of the 19th century. Secondly, 
perhaps even more important are the compositions in which the Hungaricisms are the only external elements. The principal example is Rondo ungarese, Weber's most successful and comprehensive attempt at style hongrois. The work relies heavily on the legacy of Haydn: it attempts to present the style in a finely-wrought, virtuosic form, belonging to the "classical" trend of style hongrois starting out from Haydn's work.

Schubert also set out from this point of departure. The Hungarian elements in his early Quartet in $g$ minor quite unambiguously refer back to Haydn's Hungaricisms, in a dual stylistic play, as it were. Later, however, this attitude became demoted in his work, giving way to an ambition to use the verbunkos material merely as raw material indeed and not the target of stylistic imitation. The composer presented the borrowed elements transsubstantiated, removed from the original but preserving the essential features. Through marked stylization Schubert rendered these elements, musical factors (motifs, rhythm, form, intonation, sound) capable of creating a new, though not quite unprecedented aspect of style hongrois. This aspect is the synthesis of new forms of expression and contents immanently implied by the Hungarian character. The expansion of the emotional power and expressive range of the Hungarian intonation can first be detected in some of Beethoven's works with Hungarian allusions. Schubert brought this Beethovenian trend to efflorescence in such works of his as Divertissement à l'hongroise, Symphony in $C$ major, Octet in $F$ major, Fantasy in $C$ major and String Quintet in $C$ major. The subtle rich spectrum of emotional hues, the intense, almost palpable presence of contents and moods in the music turn Schubert's style hongrois into compositions suggestive and authentic. The formal, motivic and structural elements that incorporate essential features of the source repertory into the musical process provide the appropriate frame for the fullest possible embodiment of the Hungarian character. It is first in Schubert's compositions that style hongrois reached the significance and high artistic merit that was later to be encountered in the Hungarian-related works of Liszt and Brahms. 


\section{References}

Bellman: Style Hongrois

Bellman, Jonathan: The Style Hongrois in the Music of Western Europe. Northeastern Univerity Press, Boston 1993

BÓNIS, Ferenc: "Beethoven és a magyar zene" [Beethoven and Hungarian Music] In: $\mathrm{Ma}$ gyar Zene 1971, pp. 30-36

Brown: Schubert

Brown, Maurice J. E.: Schubert. A Critical Biography. Da Capo PressNew York, 1977

DOMOKOS, Mária: "Verbunkos dallam Schubert gitárkvartettjében" [Verbunkos melody in Schubert's gitar quartet] In: Zenetudományi dolgozatok. MTA Zenetudományi Intézet, Budapest 1978, pp. 57-70

DOMOKOS, Mária: "Schubert magyaros divertimentójáról” [Schubert's Divertissement à l'hongroise] In: Muzsika 40, no. 12 (December 1997), pp. 6-10

Einstein: Schubert

EINSTEIN, Alfred: Schubert. Transl. David Ascoli. Cassell and Comp. Ltd., London 1951)

FEIL, Arnold: "Two Analyses. 2. Moment musical in F minor, op. 94 no. 3 (D 780)" Translated by Walter Frisch. In: Schubert. Critical and Analytical Studies, ed. Walter Frisch University of Nebraska Press, Nebraska1986, pp. 116-125

FLOROS, Constantin: "Carl Maria von Weber-Grundsätzliches über sein Schaffen” In: Carl Maria von Weber, ed. by Heinz Klaus Metzger and Rainer Riehn (Musik-Konzepte 52, November 1986), pp. 5-21

HINRICHSEN, Hans-Joachim: "Spätstil: 1827/28. Die Kammermusik" In: Schubert Handbuch, ed. Walther Dürr and Andreas Krause. Bärenreiter, Kassel 1997, pp. 499-507

Istvánffy: All'Ongarese

ISTVÁNFFY, Tibor: All'Ongarese. Studien zur Rezeption ungarischer Musik bei Haydn, Mozart und Beethoven. Tibor Istvánffy, Heidelberg 1982

KIEMLE, Hans Dieter: “Das Rätsel um Schubert in Czúz” In: Schubert durch die Brille January 1998 (Mitteilung 20), pp. 131-132

KINDERMAN, William: "Schubert's Tragic Perspective" In: Schubert. Critical and Analytical Studies, ed. Walter Frisch. Univ. of Nebraska Press, Nebraska 1986, pp. 65-83

Major: Bihari

MAJOR, Ervin: “Bihari János”. In: Zenei Szemle. Budapest 1928, pp. 5-27

Major: Fejezetek

MAJOR, Ervin: "Beethoven és Magyarország” [Beethoven and Hungary] In: Fejezetek a magyar zene történetéből. Zenemükiadó, Budapest1967, pp. 58-63

MÁTRAY, Gábor: "Bihari János magyar népzenész életrajza" [The Biography of the Hungarian musician, János Bihari] In: A Muzsikának Közönséges Története és egyéb írások. Magvető Könyvkiadó, Budapest1984, pp. 288-304

MÁTRAY, Gábor: “A Muzsikának Közönséges Története” [General History of Music]. In: A Muzsikának Közönséges Története és egyéb írások., Budapest 1984), pp. 7-171

PAPP, Géza: “A korai verbunkos stíluselemei XVIII. századi közhasználatú zenénkben” [Stylistic Elements of the Early Verbunkos in 18th Century Everyday Music]. In: $\mathrm{Ma}$ gyar Zene 1976, pp. 222-247 
PAPP, Géza: "Die Quelle der "Verbunkos-Musik". Ein bibliographischer Versuch. A) Gedruckte Werke I. 1784-1823" In: Studia Musicologica 1979, pp. 151-217

Papp: Verbunkoskiadványok

PAPP, Géza: “További adatok a verbunkoskiadványok megjelenési idejéhez (1822-1848) [Further data about verbunkos-publications (1822-1848)] In: Magyar Zene 1984, pp. 245-267

Papp: Hungarian Dances

PAPP, Géza: Hungarian Dances 1784-1810. Musicalia Danubiana vol. 7. MTA Zenetudományi Intézet, Budapest 1986

Papp: Tánczene

PAPP, Géza: Tánczene, szórakoztató zene. Ungaresca, hajdútánc, korai verbunkos. [Dance music, entertaining music. Ungaresca, Heyduck-dance, early verbunkos]. Unpublished article belonging to the Institute for Musicology of HAS.

Podmaniczky: Napló 1

PODMANICZKY, Frigyes br.: Naplótöredékek. 1824-1886. 1. 1824-1844 [Diary fragments. 1824-1886, vol. 1, 1824-1844]. Grill Károly, Budapest 1887

Sárosi: Cigányzene

SÁrosi, Bálint: Cigányzene ... [Gipsy Music ...]. Gondolat Kiadó, Budapest 1971

Sárosi: Parasztok cigányzenészek

SÁROSI, Bálint: "Magyar parasztok és cigányzenészek" [Hungarian peasants and Gipsy musicians]. In: Magyar Zene 1972, pp. 24-37, 144-163

Sárosi: Hangszeres népzene

SÁROSI, Bálint: A hangszeres magyar népzene [The Hungarian instrumental folk music]. Püski, Budapest 1996

Sárosi: Verbunkos

SÁROSI, Bálint: A verbunkos a tánczenei hagyományban [The verbunkos in dance music tradition]. Unpublished article belonging to the HAS Institute of Musicology.

Schubert Dokumente

Schubert. Die Dokumente seines Lebens. Gesammelt und erläutert von Otto Erich Deutsch. Bärenreiter, Kassel 1964

Somfai: Haydn zongoraszonátái

SOMFAI, László: Joseph Haydn zongoraszonátái. Hangszerválasztás és elöadói gyakorlat, müfaji tipológia és stíluselemzés [The keyboard sonatas of Joseph Haydn: Instruments and performance practice, genres and styles]. Zenemükiadó, Budapest 1979

Spitta-Warrack: Weber

SPITTA, Philipp - WARRACK, John: "Carl Maria von Weber" In: The New Grove Dictionnary of Music and Musicians, ed. by Stanley Sadie. Macmillan Publishers Ltd., London 1980, vol. 20, pp. 241-264

Steinbeck: Schubert Sinfonien

SteINBECK, Wolfram: "Die "Grosse C-Dur-Sinfonie": Sinfonie Nr. 8. in c. Die Sinfonien" In: Schubert Handbuch, ed. Walther Dürr and Andreas Krause. Bärenreiter, Kassel: 1997, pp. 642-661

Szabolcsi: Romantikus müzene

SZABOLCSI, Bence: "A magyar romantikus müzene fö irányai" [The main tendencies of Hungarian romantic art music]. Budapesti Szemle, 1940, pp. 124-231 
Szabolcsi: $A X I X$. század

SZABOLCSI, Bence: A XIX. század magyar romantikus zenéje [Hungarian romantic music in the 19th century]. Zenemükiadó, Budapest1951

Szabolcsi: Haydn

SZABOLCSI, Bence: Haydn és a magyar zene [Haydn and Hungarian music]. Magyar Tudomány, 1959, pp. 631-638

Szabolcsi: $M Z K$

SZABOLCSI, Bence: A magyar zenetörténet kézikönyve [Handbook of the Hungarian music history]. Ed. Ferenc Bónis. Zenemükiadó, Budapest 1979

Ujfalussy: Beethoven III.

UJFALUSSY, József: "Hogyan kerülnek a magyarok Beethoven III. szimfóniájának utolsó tételébe?" [How do the Hungarians get into the last movement of Beethoven's 3rd symphony?] In. Magyar Zene 1960, pp. 7-15

Vitalová: Zseliz

VITALOVÁ, Zuzana : "Schubert in Zseliz" In: Schubert durch die Brille Jan. (Mitteilung 8) 1992, pp. 93-102

Vitalová: Umkreis

VITALOVÁ, Zuzana: "Schubert im Umkreis von Zseliz" In: Schubert durch die Brille (Mitteilung 16/17), Jan. 1996, pp. 39-40

Zschacke/Weber

ZsCHACKE, Günter: Carl Maria von Weber. Romantiker im Aufbruch. Verlag Max SchmidtRömhild, Lübeck 1985 